\title{
A systematic revision of Tatia (Siluriformes: Auchenipteridae: Centromochlinae)
}

\author{
Luisa Maria Sarmento-Soares ${ }^{1,2}$ and Ronaldo Fernando Martins-Pinheiro ${ }^{2}$
}

The auchenipterid catfish genus Tatia is revised. Twelve species are recognized including three described as new. Tatia is diagnosed by the hyomandibula elongated anterodorsally, the anal-fin base of adult males reduced in length, and the caudal peduncle laterally compressed and deep with a middorsal keel. Tatia aulopygia occurs in the Madeira river drainage and is distinguished by the reduced cranial fontanel in adults and male modified anal fin with middle rays reduced in length. Tatia boemia, known from the upper Uruguay river drainage, is distinguished by its unique color pattern with dark chromatophores on the sides of body. Tatia brunnea from river basins in Suriname and French Guiana and the Negro river drainage, Amazon basin, is recognized by its wide head and mouth and by the male modified anal fin with sharply pointed tip. Tatia dunni, from the upper Amazon basin, is recognized by its narrow head, long postcleithral process in some specimens, and body coloration with irregular blotches or stripes. Tatia galaxias, endemic to the Orinoco river basin, is distinguished by its large eye and short snout. Tatia gyrina, distributed in the upper and central Amazon basin and in northern Suriname, has a uniquely reduced mesethmoid, slightly protruding lower jaw, second nuchal plate with slightly concave lateral borders, third nuchal plate reduced, small prevomer, low number of ribs, low number of vertebrae and sexual dimorphism regarding intumescent male genital papilla. Tatia intermedia, recorded from central and lower Amazon basin, Tocantins river, and coastal drainages in Guyana, Suriname, French Guiana, and eastern Pará State, Brazil, is distinguished by the short postcleithral process, small eye and long snout. Tatia neivai, from the upper Paraná river, Paraguay river and upper Paraíba do Sul river basin, is distinguished by its unique vertebral count and caudal-fin coloration consisting of transverse dark bars. Tatia strigata, from central Amazon basin and Negro river, is distinguished by its horizontally striped color pattern and the modified male anal fin with middle rays reduced in length. Tatia caxiuanensis, a new species described from the Curuá river, lower Amazon basin, is recognized by its wide cranial fontanel and distinctive anal fin in mature males. Tatia meesi, a new species described from the Essequibo river basin, Guyana, is distinguished from congeners by the cranial fontanel with two separate openings and thin nasal bone. Tatia nigra, a new species described from the central Amazon basin, is distinguished by its short postcleithral process, low number of vertebrae, and dark color pattern. All twelve species of Tatia are described or redescribed and a key to species is provided.

O gênero Tatia de auquenipterídeos é revisado. Doze espécies são reconhecidas incluindo três descritas como novas. Tatia é reconhecido pelo hiomandibular fortemente fendido anterodorsalmente, base da nadadeira anal de machos maduros reduzida em tamanho, e pelo pedúnculo caudal lateralmente comprimido e alto com uma quilha médio-dorsal. Tatia aulopygia ocorre na drenagem do rio Madeira e é distinguida pela fontanela craniana reduzida em adultos e pela nadadeira anal em machos maduros fendida, pela redução em tamanho dos raios medianos. Tatia boemia, conhecida da drenagem do alto rio Uruguai, é reconhecida por seu padrão de colorido único com cromatóforos escuros pelas laterais do corpo. Tatia brunnea, de bacias hidrográficas no Suriname e Guiana Francesa e ainda da drenagem do rio Negro na Amazônia, é reconhecida pela ampla largura da cabeça e boca e pela nadadeira anal modificada em machos com extremidade pontiaguda. Tatia dunni, do alto Amazonas, é reconhecida pela cabeça estreita, pelo processo pós-cleitral longo em alguns espécimens, e pela coloração do corpo com manchas irregulares ou faixas claras. Tatia galaxias, endêmica da bacia do rio Orinoco, é distinguida pelos grandes olhos e focinho curto. Tatia gyrina, com ocorrência pelo alto e médio Amazonas, e pelos rios do norte do Suriname, possui mesetmóide reduzido, mandíbula levemente prognata, segunda placa nucal com bordo lateral estreito, terceira placa nucal reduzida, pré-vomer pequeno, reduzido número de costelas, pequeno número de vértebras e dimorfismo sexual onde a papila genital masculina é entumescida. Tatia

\footnotetext{
${ }^{1}$ Laboratório de Ecologia de Peixes, sala 525, Pavilhão Haroldo Lisboa, Departamento de Ecologia, Instituto de Biologia Roberto Alcântara Gomes, Universidade Estadual do Rio de Janeiro. Av. São Francisco Xavier, 524; Maracanã, 20550-013 Rio de Janeiro, RJ, Brazil. luisa@nossacasa.net

${ }^{2}$ Museu de Biologia Prof. Mello Leitão, Laboratório de Zoologia. Av. José Ruschi, 4, Centro, 29650-000 Santa Teresa, ES, Brazil. ronaldo@nossacasa.net
} 
intermedia é registrada para o médio e baixo rio Amazonas, rio Tocantins e ainda para drenagens costeiras na Guiana, Suriname, Guiana Francesa e leste do Pará no Brasil. É distinguida pelo processo do pós-cleitro curto, olhos pequenos e focinho longo. Tatia neivai, do alto rio Paraná, rio Paraguai e alto rio Paraíba do Sul, é distinguida pela contagem vertebral exclusiva e pela coloração da nadadeira caudal com barras transversais escuras. Tatia strigata, distribuída pelo médio Amazonas e rio Negro é reconhecida pelo padrão de colorido com listras horizontais irregulares e nadadeira anal modificada fendida em machos, com raios medianos reduzidos em tamanho. Tatia caxiuanensis, nova espécie, descrita para o rio Curuá no baixo Amazonas, é reconhecida pela fontanela craniana ampla e pela nadadeira anal de machos maduros distinta. Tatia meesi, nova espécie, descrita para o rio Essequibo, Guiana, é diferenciada de seus congêneres pela fontanela craniana com duas aberturas separadas e pelo osso nasal afilado. Tatia nigra, nova espécie, descrita para o médio Amazonas, é distinguida pelo processo pós-cleitral curto, pelo número reduzido de vértebras e pelo padrão de colorido escurecido. Todas as doze espécies de Tatia são redescritas ou descritas e uma chave de identificação é fornecida.

Key words: South America, Freshwater, Catfish, Taxonomy, Centromochlus.

\section{Introduction}

The subfamily Centromochlinae comprises small to medium size auchenipterid catfishes that share derived anal-fin morphology in males (Ferraris, 1988; Soares-Porto, 1998). Four genera, Centromochlus, Tatia, Glanidium, and Gelanoglanis, comprising 31 species, are presently recognized as valid in the subfamily (Ferraris, 2007).

Tatia comprises a group of relatively small (20-150 mm standard length), nocturnal auchenipterids [or centromochlins] that feed on small fruits and invertebrates (H. A. Britski, M. Goulding, pers. comm.). They are endemic to South America east of the Andes and are present in most of major drainages, including the Orinoco, Amazon, ParanáParaguay, and Uruguay, as well as northern coastal rivers from the Essequibo to Amapá State and Marajó Island, Brazil. Tatia is absent in the São Francisco river basin and small riverine basins along the Brazilian east coast. Tatia is the most speciose genus in the subfamily, with 12 species recognized here (Table 1). Tatia species occur in lentic sections of igarapés, rivers, and lakes, where they remain hidden in submerged trunks or rocky crevices during the day and emerge only at night to forage (Lowe-McConnell, 1964, 1975, 1987; Soares-Porto, 1995). At night, individuals of Tatia usually remain close to the surface near river banks or in the middle of the river, swimming in a very peculiar way (fast and erratic), and capturing fallen insects (F.C.T. Lima, pers. comm.). Some species occur in black water rivers, but none are restricted to these environments. Many members of the genus are beautifully colored and, consequently, very attractive to the ornamental fish trade. Tatia species, however, are not well suited for captivity because of their apparent intolerance for low oxygen conditions. Most do not survive transport to Europe and North America (Sands, 1984).

The generic name Tatia was proposed by Miranda Ribeiro (1911: 360) for Charles Tate Regan of the British Museum of Natural History, London, in honor of his many contributions to the knowledge of the South American freshwater fishes. The group was erected to include two species previously ascribed to Centromochlus: Tatia intermedia (Steindachner) and $T$. aulopygia (Kner), based on the presence of a genital papilla over the anterior anal-fin rays (Miranda Ribeiro,
1911:353). After Miranda Ribeiro's (1911) description the name Tatia was mentioned only in catalogues (e.g. Gosline, 1945) and practically forgotten. Subsequent authors such as Eigenmann \& Allen (1942) and Fowler (1945a) described new species in the genus Centromochlus, without mentioning Tatia. Boeseman (1953) referred to Tatia, but described a new species as Centromochlus creutzbergi. Britski (1972) considered Tatia to be a junior synonym of Glanidium Lütken due to similarities of sexually dimorphic features. In his study of auchenipterids primarily from Suriname Mees (1974) redescribed Tatia and expanded the genus to 14 species, six of which he described as new: T. brunnea, T. concolor, T. galaxias, T. punctata, T. reticulata and T. simplex. Four additional species of Tatia have been described subsequently (Mees, 1988; Royero, 1992; Soares-Porto, 1995; Koch \& Reis, 1996).

Regarding interrelationships among auchenipterid genera, Ferraris (1988) and Curran (1989) presented independent phylogenetic hypotheses based on cladistic analysis. Ferraris (1988) recognized a monophyletic basal clade within auchenipterids "Centromochlidae" and removed some species previously assigned to Tatia to two undescribed genera, restricting the nominate genus to: T. aulopygia, T. intermedia, T. dunni, T. galaxias, and one undescribed species. Curran (1989) questioned the monophyly of the speciose genus Tatia. The author considered Tatia and Centromochlus as only distantly related; assigning Tatia as close to Auchenipterichthys. Soares-Porto (1998) stated Tatia sensu stricto as a monophyletic unit restricted to eight species: T. aulopygia, $T$. boemia, T. brunnea, T. creutzbergi, T. gyrina, T. intermedia, T. neivai, and T. strigata. Other species previously assigned to Tatia were transferred to Centromochlus, on the basis of derived characters (Soares-Porto, 1996, 1998). Most recently Ferraris (2007) listed twelve valid species of Tatia: T. aulopygia, T. boemia, T. brunnea, T. creutzbergi, T. dunni, T. galaxias, T. gyrina, T. intermedia, T. musaica, T. neivai, $T$. simplex, and T. strigata.

The present paper gives a reappraisal of Tatia based on examination of numerous specimens in addition to those available to previous authors. Patterns of variation within and between species are considered throughout their distributions. 
Table 1. Taxonomic list of nominal species assigned to Tatia by previous authors and the status of those species as recognized in the present study.

\begin{tabular}{|c|c|c|c|c|}
\hline Nominal species & Mees (1974) & Ferraris (2007) & Assignment herein & Taxonomic status \\
\hline Centromochlus aulopygius Kner, 1857 & Tatia aulopygia & Tatia aulopygia & Tatia aulopygia & Valid \\
\hline Tatia boemia Koch \& Reis, 1996 & - & Tatia boemia & Tatia boemia & Valid \\
\hline Tatia brunnea Mees, 1974 & Tatia brunnea & Tatia brunnea & Tatia brunnea & Valid \\
\hline Tatia caxiuanensis, new species & - & - & Tatia caxiuanensis n.sp. & Valid \\
\hline Centromochlus dunni Fowler, 1945 & Tatia intermedia & Tatia dunni & Tatia dunni & Valid \\
\hline Tatia galaxias Mees, 1974 & Tatia galaxias & Tatia galaxias & Tatia galaxias & Valid \\
\hline Centromochlus gyrinus Eigenmann \& Allen, 1942 & Tatia gyrina & Tatia gyrina & Tatia gyrina & Valid \\
\hline Centromochlus intermedius Steindachner, 1877 & Tatia intermedia & Tatia intermedia & Tatia intermedia & Valid \\
\hline Tatia meesi, new species & - & - & Tatia meesi $\mathrm{n} . \mathrm{sp}$. & Valid \\
\hline Glanidium neivai Ihering, 1930 & Tatia neivai & Tatia neivai & Tatia neivai & Valid \\
\hline Tatia nigra, new species & - & - & Tatia nigra $\mathrm{n} . \mathrm{sp}$. & Valid \\
\hline Tatia strigata Soares-Porto, 1995 & - & Tatia strigata & Tatia strigata & Valid \\
\hline Centromochlus altae Fowler, 1945 & Tatia altae & Centromochlus altae & Centromochlus altae & Valid \\
\hline Tatia concolor Mees, 1974 & Tatia concolor & Centromochlus concolor & Centromochlus concolor & Valid \\
\hline Centromochlus creutzbergi Boeseman,1953 & Tatia creutzbergi & Tatia creutzbergi & Junior synonym of Tatia gyrina & Junior synonim \\
\hline Tatia musaica Royero, 1992 & - & Tatia musaica & $\begin{array}{l}\text { "Centromochlus" musaicus [incertae } \\
\text { sedis in Centromochlinae] }\end{array}$ & $\begin{array}{l}\text { Valid, incertae sedis } \\
\text { in Centromochlinae }\end{array}$ \\
\hline Centromochlus perugiae Steindachner, 1882 & Tatia perugiae & Centromochlus perugiae & Centromochlus perugiae & Valid \\
\hline Tatia punctata Mees, 1974 & Tatia punctata & Centromochlus punctatus & Centromochlus punctatus & Valid \\
\hline Tatia reticulate Mees, 1974 & Tatia reticulata & Centromochlus reticulatus & Centromochlus reticulatus & Valid \\
\hline Centromochlus schultzi Rössel, 1962 & Tatia schultzi & Centromochlus schultzi & Centromochlus schultzi & Valid \\
\hline Tatia simplex Mees, 1974 & Tatia simplex & Tatia simplex & $\begin{array}{l}\text { "Centromochlus" simplex } \\
\text { [incertae sedis in Centromochlinae] }\end{array}$ & $\begin{array}{l}\text { Valid, incertae sedis } \\
\text { in Centromochlinae }\end{array}$ \\
\hline
\end{tabular}

\section{Material and Methods}

Osteological features were examined in cleared and stained (CS) specimens prepared according to the procedures of Taylor \& van Dyke (1985). Prior to clearing and staining, specimens were dissected when possible to determine gut contents, sexual maturity of gonads, and record myological information. Osteological data from some types or specimens poorly represented in ichthyological collections were obtained from radiographs (noted as " $R$ " in the Material Examined section). Nomenclature of osteological elements follows The Zebrafish Information Network (ZFIN). Muscle names follow Sarmento-Soares \& Porto (2006). Drawings were rendered from digital photographs prefereably of cleared and stained specimens. Straight-line measurements were made with a digital caliper, and recorded in tenths of a millimeter.

Measurements included: standard length (SL, from snout tip to caudal-fin base); body depth (on nuchal shield, from origin of dorsal-fin spine to the belly); body width (widest distance between lateral surfaces of cleithra, taken between anterior-most margin of cleithral bone beneath pectoral-fin origin); caudal-peduncle depth (least distance between dorsal and ventral surfaces of caudal peduncle); caudal-peduncle length (from base of posterior-most anal-fin ray to point coinciding with origin of lower unbranched caudal-fin ray); predorsal length (from snout tip to origin of dorsal fin); preanal length (from snout tip to anal-fin origin); prepelvic length (from snout tip to pelvic-fin origin); dorsal-fin origin to pectoral-fin origin; dorsal-fin origin to pelvic-fin origin; pectoralfin origin to pelvic-fin origin; prepectoral length (from snout tip to pectoral-fin origin); dorsal-fin base (from origin of dorsal-fin spine to posterior-most base of dorsal-fin insertion); adipose-fin base (from origin of adipose fin fold to its posterior-most base); anal-fin base (distance between genital opening and posterior-most base of anal-fin insertion, measured under the same criteria for both males and females); dorsalfin spine length (from base of spine to its distal tip); pectoralfin spine length (from origin of spine to its distal tip, taken with the spine erected); postcleithral (humeral) process length (from anterodorsal margin of exposed process to posteriormost tip of process); first branched pelvic-fin ray (from base to tip of first branched pelvic-fin ray); longest anal-fin ray (from base to tip of first branched anal-fin ray); head length (HL, from snout tip to bony end of opercle); head width (between dorsalmost extents of opercular openings); snout depth (distance in median sagittal plane between posterior nostril and midventral contour of body); interorbital distance (least distance between dorsalmost margins of bony orbit); left internarial width (between left anterior and left posterior nostrils); anterior internarial distance (transverse distance between anterior nostrils); posterior internarial distance (transverse distance between posterior nostrils); snout length (from snout tip to anteriormost margin of eye); maxillary-barbel length (from base to tip, with barbel retracted); outer mentalbarbel length (from base to tip, with barbel retracted); inner mental-barbel length (from base to tip, with barbel retracted); orbital diameter (greatest horizontal dimension of eyeball); mouth width (between corners of closed mouth).

Counts of fin rays and bony elements were obtained from alcohol-preserved and cleared and stained specimens. Vertebral counts included all rib-bearing centra but did not include any of the anterior, complex centrum elements without ribs, following Ferraris \& Fernandez (1987), and included the compound caudal centrum $(\mathrm{PU} 1+\mathrm{U} 1)$ as the last element. Hemal spine counts accompany the numbers for correspondent vertebra, as shown in Fig. 1. Count of branchiostegal rays were done only in cleared and stained specimens. The direction of dorsal and pectoral-fin spine serrations are referred to as antrorse for those pointing away from base of spine and retrorse for those bent towards base of spine. Male modified 


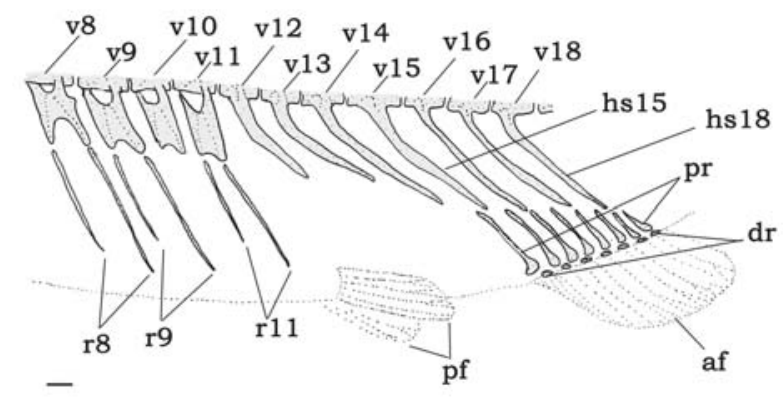

Fig. 1. Schematic representation of partial axial skeleton of Tatia boemia MCP 12949, $59.9 \mathrm{~mm}$ SL. Left side lateral view. Abbreviations: af, anal fin; dr, distal radials; hs15- hs18, hemal spines

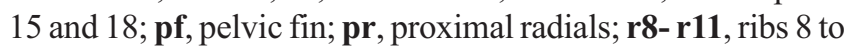
$11 ; \mathbf{v 8 -} \mathbf{v 1 8}$, vertebral centra 8 to 18 . Scale bar $=1.0 \mathrm{~mm}$.

anal-fin segmented rays (lepidotrichia) may have adjacent segments with curved border, forming denticulations herein refered to as antrorse or retrorse.

Institutional abbreviations follow Reis et al. (2003), with the exception of MBML for Museu de Biologia Professor Mello Leitão, Santa Teresa, Espírito Santo, Brazil and NUPELIA for Núcleo de Pesquisas em Limnologia, Ictiologia e Aquicultura/ Fundação Universidade Estadual de Maringá, Maringá, Paraná, Brazil.

\section{Results}

\section{Tatia Miranda Ribeiro}

Tatia Miranda Ribeiro, 1911: 360 [type species: Centromochlus intermedius Steindachner, 1877, by subsequent designation by Jordan, 1920: 545 . Gender: feminine].

Diagnosis. Tatia is distinguished among the Centromochlinae by three uniquely derived features. The hyomandibula is elongate anterodorsally, not contacting the narrow metapterygoid and, instead, connected only to the trapezoidal quadrate (Fig. 2); anal-fin base of adult males is reduced (anal-fin base length $3.3-8.0 \% \mathrm{SL}$ ); and caudal peduncle is compressed and deep (caudal-peduncle depth 10.1-18.6\% SL), with a middorsal keel posterior to adipose fin.

A unique combination of restricted characters aids in distinguishing Tatia: first (anteriormost) nuchal plate present (Fig. 3, n1); infraorbital 1 bone short, limited to anterior corner of orbit; eye moderately large, between 17.4-42.9\% HL; maxilla shorter than or same length as autopalatine; retractor tentaculi muscle absent, functionally substituted by maxillomandibular ligament (Sarmento-Soares \& Porto, 2006); adult males with modified anal fin (all species), and first unbranched anal-fin ray non-segmented or with segments fused (except in T. brunnea).

Generic description. Tatia comprises species with somewhat robust head; caudal peduncle much compressed laterally and deep; well-developed adipose eye lid; eye moderately large, and latero-dorsally located. Following characters used to distinguish species of Tatia (illustrations based on T. gyrina): Head: cranial fontanel always present (Fig. 3, fo); premaxilla transversely elongated, meeting its counterpart medially; autopalatine tubular, oriented obliquely to longitudinal axis of body; maxilla very small, shorter than or same length as autopalatine; three nuchal plates present (Fig. 3, n1, n2, n3). Epioccipital process small, connected to third nuchal plate by ligaments (Fig. 3, pe). Mullerian ramus with distal tip shaped as slightly curved disc, its concave face superficially adjoined to anterior wall of gasbladder. Prevomer usually with well developed arrow-shaped lateral processes or with short lateral process. Prevomerian teeth present in T. galaxias and $T$. intermedia.

Suspensorium (Fig. 2): Suspensorium bones in Tatia similar among all species and distinctive among Centromochlinae. Hyomandibula narrow, elongate, projected anteriorly as short membranous lamina (Fig. 2, hy). Anterior laminar projection of hyomandibula sutured only to quadrate, through cartilage ventrally and deeply dentate suture dorsally. Metapterygoid conical, dorsally sharp, with little laminar extension (Fig. 2, $\mathrm{mt}$ ), joined to quadrate via cartilage block only ( $T$. gyrina, $T$. caxiuanensis, T. meesi, T. strigata) or cartilage plus dentate suture (T. aulopygia, T. boemia, T. brunnea, T. dunni, T. galaxias, T. intermedia, T. neivai, T. nigra). Suspensorium deeply notched anterodorsally, thus metapterygoid not contacting hyomandibula. Quadrate trapezoidal, with broad base (Fig. 2, qu), connected to preopercle, hyomandibula and metapterygoid; long preopercle (Fig. 2, po) ventral margins sutured to both quadrate and hyomandibula; suprapreopercle present as short or robust canal bone (Fig. 2, sp); opercle laminate and broadly subtriangular (Fig. 2, op).

Hyoid arch (Fig. 4): Urohyal narrow (Fig. 4, uh); short dorsal hypohyal (Fig. 4, dh) associated with comparatively large ventral hypohyal (Fig. 4, vh); anterior ceratohyal well developed (Fig. 4, ac), posterior ceratohyal smaller (Fig. 4, pc); branchiostegal ray articulated to hyoid arch; branchiostegal rays 5-7; 3-5 on anterior ceratohyal and two on posterior ceratohyal; posteriormost usually largest and flattened. No branchiostegal ray associated with interceratohyal cartilage between bones.

Pharyngeal (gill) arches (Fig. 5): Basibranchial 1, in contact with urohyal (Fig. 5, ab), anterior to basibranchial 2; basibranchial 2 forming osseous rod, broadest anteriorly (Fig. $5, \mathrm{bb} 2$ ) and usually separated by gap from basibranchial 3; basibranchial 3 shorter (Fig. 5, bb3), also broadest anteriorly; basibranchial 4 large, flattened and completely cartilaginous (Fig. 5, bb4); basibranchial 2 bordered laterally by cartilaginous head of hypobranchial 1; basibranchial 3 between cartilaginous head of hypobranchial 2 and cartilaginous hypobranchial 3; basibranchial 4 bordered laterally by cartilaginous head of ceratobranchial 4 and caudally by cartilaginous head of ceratobranchial 5. Hypobranchial 1 mostly osseous, elongate and expanded laterally, subtriangular, with cartilaginous ends; hypobranchial 2 mostly cartilaginous, subtriangular, with medial osseous part; hypobranchial 3 com- 
pletely cartilaginous, more trapezoidal (Fig. 5, hb 1-3); hypobranchial 4 absent. Five ceratobranchials present, mostly ossified, with cartilage on both ends (Fig. 5, cb 1-5). First ceratobranchial supporting single row of rakers (not illustrated); fifth ceratobranchial expanded postero-medially to support lower pharyngeal toothplate with short conical teeth. Five epibranchials, all but fifth largely ossified except for cartilaginous ends; epibranchials 1 and 2 rod-like, without rakers; epibranchial 3 with posterior uncinate process; epibranchial 4 broad, with laminar extension; epibranchial 5 cartilaginous, reduced, located in axil between cartilaginous ends of epibranchial 4 and ceratobranchial 4. Pharyngobranchial 1 absent; pharyngobranchial 2 short, cartilaginous, somewhat rounded, placed between anteromedial cartilaginous tips of epibranchials 1 and 2; pharyngobranchial 3 elongate, ossified, with expanded posterior border; pharyngobranchial 4 ossified, supporting upper pharyngeal tooth plate with short conical teeth.

Lateral line system: Infraorbital 1 short, with ventro-lateral process either clearly restricted to anterior border of eye or almost reaching ventral border of eye; infraorbitals thin and canalicular, forming incomplete or complete infraorbital series. Lateral line on body straight, inconspicuous, with ossified canal bones just anteriorly.

Fins: Dorsal fin with major spine preceded by small dorsal locking spine and followed by 3-5 branched rays; pectoral fin with one spine plus 3-5 branched rays; pelvic fin with one unbranched plus 5 branched rays, margin rounded; adipose fin above anal-fin base; anal fin with 3 unbranched plus 6-8 branched rays; caudal fin with $8+9$ principal rays, forked, lobes with rounded tips; dorsal caudal-fin lobe slightly elongate in males of some species.

Ribs and vertebrae: Pleural ribs 7-11; first rib thicker than others; ribs becoming progressively smaller posteriorly. PostWeberian vertebrae 30-39.

Sexual dimorphism. In catfishes of subfamily Centromochlinae the anal fin of sexually mature males is modified into a sperm conductor with the anal-fin rays and proximal radials directed posteriorly, aligned nearly parallel to vertebral axis (Ferraris, 1988; Soares-Porto, 1998). In mature males the anal fin is strongly modified such that it is supported by enlarged and joined proximal anal-fin radials (Ferraris, 1988; Soares-Porto, 1998) and by partially ossified distal radials. Anal-fin proximal radials are associated with the thickened and lengthened hemal spines of adjacent vertebrae. Modified male anal fin has three developed unbranched rays. The first unbranched ray is shortest, about one-quarter length of second unbranched ray, and with segments fused (except in T. brunnea). Some species have the first unbranched anal-fin ray preceded immediately by a tegumentary keel. The second and third unbranched rays are thick. In the Centromochlinae, Tatia is the only genus with species that bear segments that curve outwards, forming antrorse denticulations along the anterior margin of the third unbranched anal fin ray in adult males.

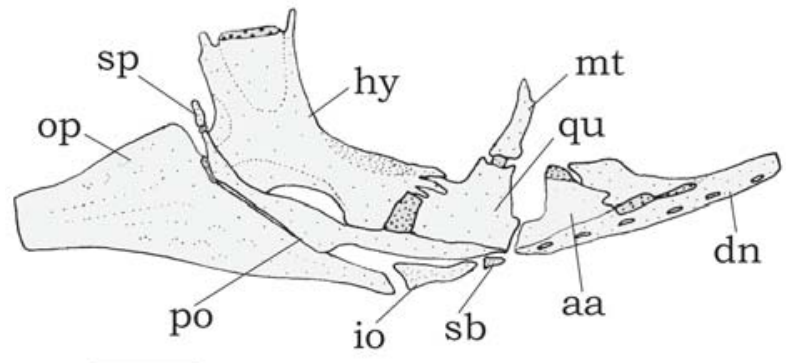

Fig. 2. Right suspensorium of Tatia gyrina, INPA 20971, 28.0 $\mathrm{mm}$ SL. Lateral view. Abbreviations: aa, angulo-articular; dn, dentary; hy, hyomandibula; io, interopercle; mt, metapterygoid; op, opercle; po, preopercle; qu, quadrate; sb, subpreopercle; sp, suprapreopercle. Scale bar $=1.0 \mathrm{~mm}$.

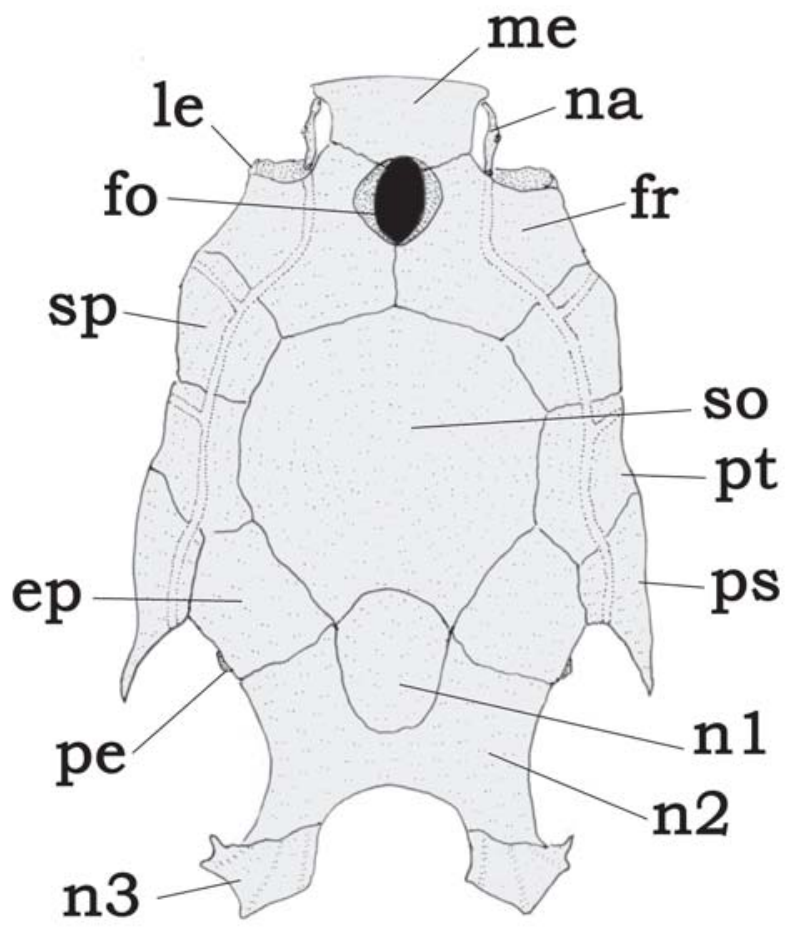

Fig. 3. Neurocranium of Tatia gyrina, INPA 20971, $28.0 \mathrm{~mm}$ SL. Dorsal view. Abbreviations: ep, epioccipital; fo, single cranial fontanel, fr, frontal; le, lateral ethmoid; me, mesethmoid; na, nasal; n1, first nuchal plate, n2; second nuchal plate; n3, third nuchal plate; pe, posterior epioccipital process; ps, posttemporal-supracleitrum; pt, pterotic; so, supraoccipital; sp, sphenotic. Scale bar $=1.0 \mathrm{~mm}$.

Remarks. Two of the nominal species assigned to Tatia by Ferraris (2007) are not herein recognized as members of this genus. Both Tatia musaica Royero and Tatia simplex Mees lack the derived characters listed above for Tatia: thin, anterodorsally elongate hyomandibula ( $v s$. broad in both $C$. musaicus and C. simplex); caudal peduncle laterally compressed ( $v s$. ellipsoid); proportionally deeper caudal peduncle, depth 10.1-18.6\% SL (vs. 7.9-9.6\% SL in C. musaicus and 9.2$10.0 \% \mathrm{SL}$ in C. simplex); first nuchal plate present (vs. ab- 


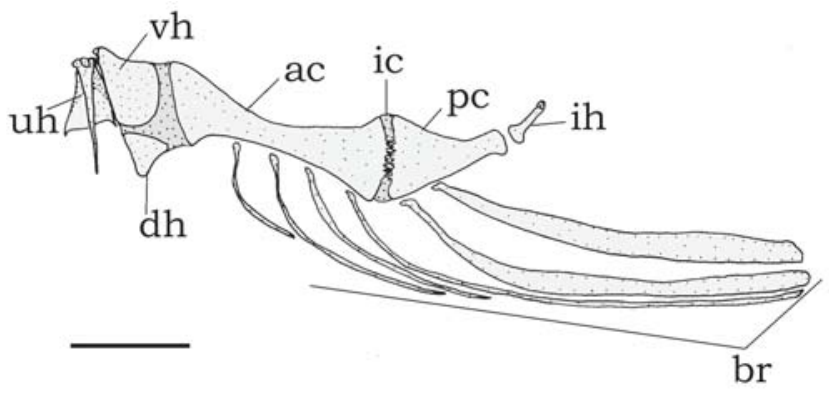

Fig. 4. Right hyoid arch of Tatia gyrina, INPA 20971, $28.0 \mathrm{~mm}$ SL. Medial view. Abbreviations: ac, anterior ceratohyal; br, branchiostegal rays; $\mathbf{d h}$, dorsal hypohyal; ic, interceratohyal cartilage; ih, interhyal; pc, posterior ceratohyal; vh, ventral hypohyal; uh, urohyal. Scale bar $=1.0 \mathrm{~mm}$.

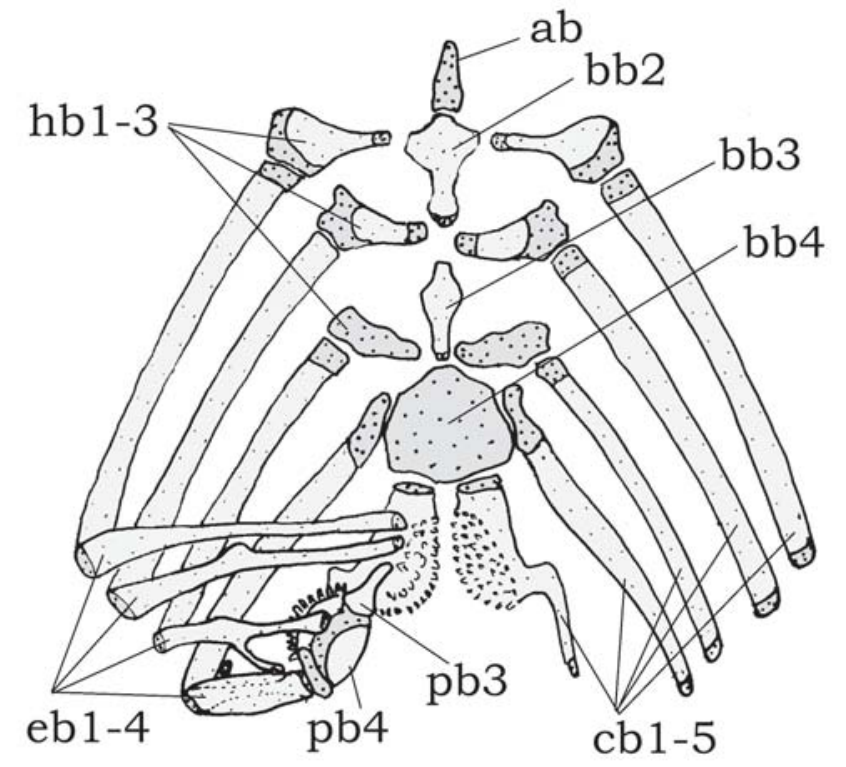

Fig. 5. Pharyngeal arches of Tatia gyrina, INPA 20971, 28.0 mm SL. Dorsal view. Abbreviations: ab, anterior (first) basibranchial; bb2, basibranchial 2; bb3, basibranchial 3; bb4, basibranchial 4; cb1-5, ceratobranchials 1 to 5 (anterior to posterior); eb1-4, epibranchials 1 to 4 (anterior to posterior); hb1-3, hypobranchials 1 to 3; pb3, pharingobranchial 3; pb4, pharingobranchial 4 . Scale bar $=1.0 \mathrm{~mm}$.

sent); maxilla shorter than or same length as autopalatine ( $v S$. longer than autopalatine). These two species are incertae sedis in Centromochlinae (see Table 1), based in part on interrelationships analysis by Soares-Porto (1996), and are herein provisionally allocated under Centromochlus.

The monophyly and interrelationships among species of Tatia were hypothesized by Soares-Porto (1998), who considered the clade T. gyrina plus $T$. creutzbergi as sister to all other Tatia species.

Inseminating reproductive mode (sensu Burns et al., 1997) has been documented within the Auchenipteridae (von Ihering, 1937; Loir et al., 1989; Meisner et al., 2000). In the centromochlin catfishes, inseminating is supposed to take place (Loir et al.,
1989; Franke, 1990), but a reproductive behavior is not yet reported. During reproductive phase, the anal-fin rays change their position probably channeling for discharge of seminal ducts, acting as a sperm conductor during reproduction. Such a morphological change was observed in some males of Centromochlus romani and also in T. nigra. The sperm probably runs along the spoon shaped anal-fin rays, and the fish may press the fin against the belly of the female, for inseminating. Morphological evidences suggesting inseminating reproductive mode in Tatia are the intumescent female genital papilla (as in T. gyrina and T. nigra) and the spoon-shaped laterally curved male anal fin (observed in T. nigra). A detailed analysis of morphological changes of the reproductive tract needs to be accomplished by histological preparations, and is out of the scope of present contribution.

Distribution. Species of Tatia are broadly distributed in the regions east of the Andean Cordilleras (Fig. 6). Tatia ranges from the Guarapiche river, Orinoco basin, in Venezuela, to the Pelotas river, Uruguay drainage, in Brazil. The group is found in major continental river basins, such as the Amazon, Orinoco and Paraná-Paraguay; as well as in the Essequibo and small coastal drainages in French Guiana, Suriname and Amapá and Marajó island in northern Brazil. Although well distributed in cis-Andean South America, the group is not known from certain drainage basins, including the São Francisco and small coastal river drainages of northeastern and far eastern Brazil. Tatia is found, however, in headwaters of Paraíba do Sul basin, São Paulo State. The absence of Tatia from certain areas may be a function of inadequate collections from those river basins or may reflect actual disjunct distributions of the group as whole.

\section{Species Account}

\section{Tatia aulopygia (Kner, 1857)} Figs. 7-9

Centromochlus aulopygius Kner, 1857: 432, Pl. 8 (fig. 26) [type locality: Guaporé river]. -Steindachner, 1876: 664-665 [no locality]. Eigenmann \& Eigenmann, 1890: 270 [citation]. Pearson, 1937: 110 [Mamoré river drainage].

Tatia aulopygia. Miranda Ribeiro, 1911: 361 [generic designation]. Gosline, 1945: 10 [listing]. Mees, 1974: 59-63 [notes and distribution, in part, Maciel, Guaporé river]. Sands, 1984: 38-39 [listing]. Lauzanne \& Loubens, 1985: 112 [Mamoré river drainage]. Burgess, 1989:242 [listing]. Soares-Porto, 1995:204 [citation]. Soares-Porto, 1998: 331350 [citation]. Lasso et al., 2001:97 [citation]. Ferraris, 2003:476 [checklist]. Ferraris, 2007: 77 [checklist].

Centromochlus intermedius. Fisher, 1917: 422 [in part, Maciel, Guaporé river]. Pearson, 1937: 110 [Mamoré river drainage].

Diagnosis. Tatia aulopygia is distinguished from all other species of Tatia by having a short cranial fontanel, with the opening restricted to the frontals (Fig. 8); a genital papilla 


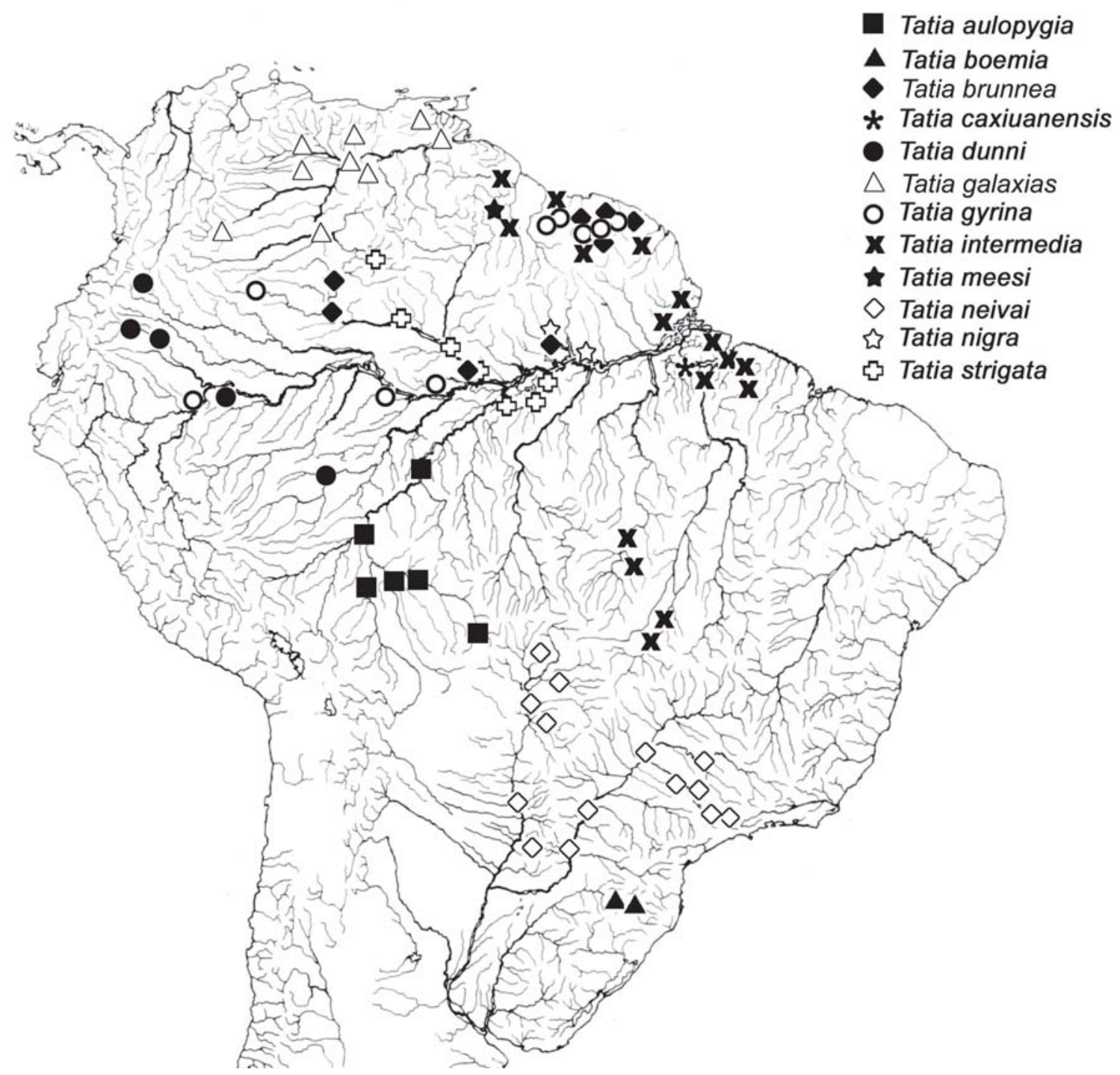

Fig. 6. Drainage map of northern South America illustrating the geographic distribution of the species of Tatia. Symbols may represent more than one locality. Base map by Marilyn Weitzman.

with thick flap of skin around the deferent duct in males (Fig. 9); and a notched anal fin in adult males (Fig. 9). The species also is distinguished from congeners by a combination of characteristics: nasal bone partially sutured to lateral margin of mesethmoid; anal fin with 7-8 branched rays; 10-11 ribs; 38-39 post-Weberian vertebrae. Additional features useful for distinguishing this species include: third nuchal plate well projected laterally with curved tip; and caudal-fin lobes of mature females similar in length, but mature males with slightly elongated upper lobe.

Description. Measured adult specimens 75.2-159.0 mm SL; morphometric data presented in Table 2. Body deep, head slightly depressed dorsoventrally. Head large, robust, outline of head in dorsal view somewhat elliptical, broader than long. Dorsal outline of trunk from dorsal-fin base to caudal peduncle increasingly compressed posteriorly. Lateral profile of head from snout tip to above opercular margin slightly convex to pectoral-fin insertion. Ventral profile of head and abdomen flat. Ventral profile of body gently curved, concave behind anal-fin origin. Head integument thin, cranial roof visible; adipose eye lid well-developed; eye dorsolaterally located in anterior portion of head; mouth terminal, upper lip extended posterolaterally as well-developed fleshy rictal fold; anterior nostril tubular, located on anterior border of snout, above lip; posterior nostril large, rounded, limited by small skin flap; transverse distance between anterior nostrils slightly shorter than distance between posterior ones. Maxillary barbel short, extending slightly beyond tip of postcleithral process, sometimes shorter; mental barbels short, tips not reaching pectoral-fin base, arranged in arc along ventral surface of jaw; inner mental barbel about $65.0-75.0 \%$ length of outer mental. Postcleithral process almost reaching vertical through origin of dorsal fin. Caudal peduncle deep, depth about 14.0$15.8 \%$ SL.

Rostral border of cranium broad with large mesethmoid; 


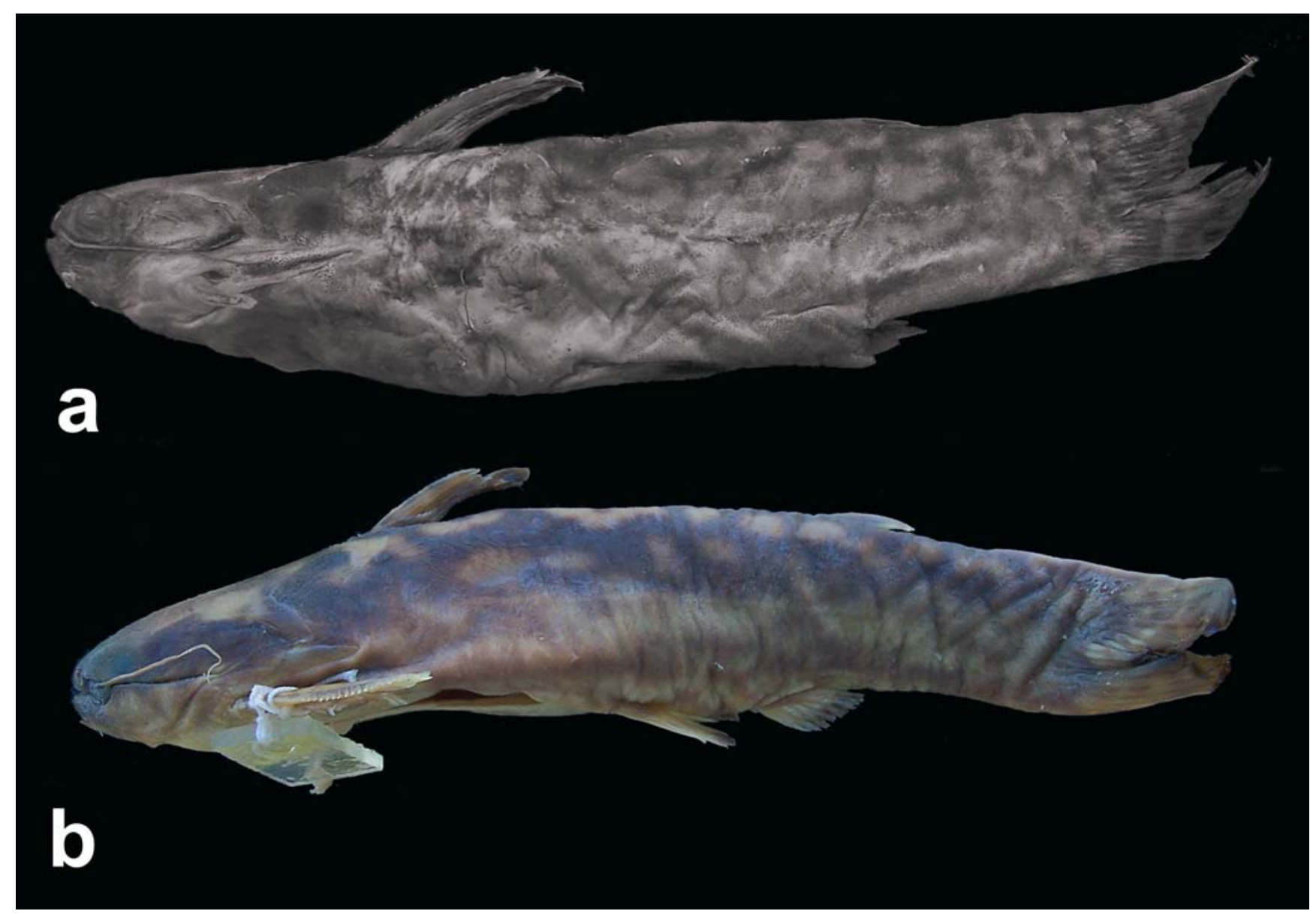

Fig. 7. Tatia aulopygia, (a) INPA 11080, male, 104.6 mm SL, Guaporé river, Amazonas State, Brazil. (b) ZMA 114.280, young female, 46.3 mm SL, Humaitá, Amazonas State, Brazil.

premaxilla underneath with synchondral articulation; cranial fontanel short, ovoid, bounded by frontal (Fig. 8); nasal ossified with wide medial flanges partially sutured to lateral margin of mesethmoid; autopalatine tubular, oriented obliquely to longitudinal axis of body; maxilla very small, shorter than autopalatine; prevomer expanded anteriorly with well developed arrow-shaped lateral processes; jaws of equal size; premaxilla and dentary with four to five rows of conical teeth. First nuchal plate somewhat pentagonal; second nuchal plate deeply concave along lateral margin; third nuchal plate curved, projected laterally. Epioccipital process small.

Suspensorium, hyoid arch and opercular bones as in generic description. Suprapreopercle present as short robust canal bone. Six branchiostegal rays articulated with hyoid arch: four with anterior ceratohyal and two with posterior ceratohyal.

Basibranchials 2 and 3 fused together forming osseous rod with broad cartilaginous anterior tip; basibranchial 4 large flattened and completely cartilaginous; fused basibranchial 2 plus 3 bordered laterally by cartilaginous head of hypobranchial 1, cartilaginous head of hypobranchial 2 and cartilaginous hypobranchial 3 . Basibranchial 4 bordered laterally by cartilaginous head of ceratobranchial 4 and posteriorly by cartilaginous head of ceratobranchial 5. Hypobranchials, ceratobranchials, epibranchials and pharyngobranchials as described in generic description.

Four infraorbital bones in incomplete series. Infraorbital 1 broad with short ventro-lateral process on anterior border of eye; remaining infraorbitals thin, reduced to canalicular portions. Infraorbital 2 smallest, close to infraorbital 1, followed by non-ossified portion of canal below eye and two posterior canal bones, one long and one short, forming posterior orbital rim. Lateral line on body with ossified canal bones posteriorly to vertical through pelvic-fin origin.

Dorsal fin I,5 ( $\mathrm{n}=7$ ); dorsal-fin spine with 14-16 antrorse serrations along entire anterior margin; posterior margin smooth. Pectoral fin I,5 $(n=7)$; pectoral-fin spine with 21-24 antrorse serrations along anterior margin; small serrations close to spine base; 14-16 retrorse serrations along posterior margin; serrations along both margins progressively larger toward spine tip. Pelvic fin i,5 ( $n=7)$; margin rounded. Adipose fin small, origin on vertical through end of anal-fin base. Anal fin iii,7-8 ( $\mathrm{n}=7)$; anal-fin pterygiophores in eight rod-like proximal radials and seven cartilaginous distal radials. Caudal fin forked, lobes with rounded tips, $8+9$ principal rays, $18-$ 20 upper procurrent, $17-20$ lower procurrent rays $(n=7)$. Pleural ribs 10-11 attached to consecutive vertebrae. PostWeberian vertebrae $38-39(n=4)$. 
Table 2. Morphometric data for Tatia aulopygia. $\mathrm{SD}=$ standard deviation.

\begin{tabular}{|c|c|c|c|c|}
\hline & Range & Mean & SD & $\mathrm{N}$ \\
\hline Standard length & $75.2-159.0$ & 92.4 & & 7 \\
\hline \multicolumn{5}{|c|}{ Percents of standard length } \\
\hline Body depth & $15.2-20.3$ & 17.8 & 1.69 & 7 \\
\hline Body width & $18.7-23.5$ & 20.4 & 1.96 & 7 \\
\hline Caudal peduncle depth & $14.0-15.8$ & 14.6 & 0.82 & 7 \\
\hline Caudal peduncle length & 23.4-28.4 & 25.9 & 1.98 & 7 \\
\hline Predorsal length & 29.3-33.3 & 31.7 & 1.37 & 7 \\
\hline Preanal length & $64.4-70.6$ & 67.5 & 1.99 & 7 \\
\hline Prepelvic length & $46.7-51.8$ & 49.4 & 1.69 & \\
\hline Dorsal origin to pectoral origin & 19.1-24.2 & 21.8 & 1.89 & \\
\hline Dorsal origin to pelvic origin & $26.0-29.5$ & 27.2 & 1.25 & \\
\hline Pectoral origin to pelvic origin & $30.5-35.5$ & 32.3 & 1.85 & 7 \\
\hline Prepectoral length & $17.8-22.5$ & 20.0 & 1.60 & 7 \\
\hline Dorsal-fin base length & $6.8-11.8$ & 9.5 & 1.91 & \\
\hline Adipose-fin base length & $7.9-12.7$ & 10.1 & 1.92 & 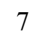 \\
\hline Anal-fin base length & $3.3-10.8$ & 7.4 & 3.39 & \\
\hline Dorsal-fin spine length & $16.0-21.2$ & 18.6 & 1.92 & 7 \\
\hline Pectoral-fin spine length & $19.5-24.0$ & 22.1 & 1.91 & 7 \\
\hline Postcleithral process lenght & $15.8-19.4$ & 16.5 & 1.86 & 7 \\
\hline First branched pelvic-fin ray & $10.7-15.3$ & 13.2 & 1.67 & 7 \\
\hline Longest anal fin ray & $5.2-12.5$ & 8.0 & 2.58 & 7 \\
\hline Maxillary barbel length & $22.0-27.3$ & 24.7 & 1.90 & 7 \\
\hline Outer mental barbel length & $7.3-13.3$ & 9.0 & 1.88 & 7 \\
\hline Mental barbel length & $4.1-10.0$ & 5.6 & 1.92 & 7 \\
\hline Head length & $21.8-26.6$ & 23.4 & 1.80 & 7 \\
\hline \multicolumn{5}{|c|}{ Percents of head length } \\
\hline Head width & $75.2-80.2$ & 78.1 & 1.84 & I \\
\hline Snout depth & $41.5-45.9$ & 44.0 & 1.79 & \\
\hline Interorbital distance & $53.2-58.9$ & 57.7 & 1.94 & \\
\hline Left internarial width & $21.1-25.0$ & 22.9 & 1.36 & I \\
\hline Anterior internarial distance & $38.4-43.8$ & 40.8 & 1.81 & r \\
\hline Posterior internarial distance & $34.5-39.5$ & 37.8 & 1.69 & I \\
\hline Snout length & $36.6-41.2$ & 38.5 & 1.89 & \\
\hline Orbital diameter & $23.1-26.5$ & 24.6 & 1.51 & t \\
\hline Mouth width & $50.4-55.5$ & 53.1 & 1.94 & 7 \\
\hline
\end{tabular}

Color in alcohol. Head and body mottled with dark and light brown patches of pigmentation, sometimes forming faint blotches irregularly distributed over sides of body (Fig. 7). Lips and chin dark brown. Dorsal fin dark brown, pectoral fin usually pale brown or not pigmented. Adipose fin pale brown, caudal fin usually with transverse bars but young specimens with whitish spots. Pelvic fins and belly whitish.

Color variation. Body coloration in $T$. aulopygia is somewhat variable, usually with large bands or blotches irregularly distributed over sides of body. In some specimens coloration is uniformly dark or pale brown, with caudal fin mottled. Some young specimens have small spots over ventrolateral parts of body and a barred caudal fin.

Mees (1974) noted the presence of longitudinal pale streaks on the body and observed irregular patches of pigmentation on specimens from the Guaporé river, but all specimens available to him are now very faded and unsuitable for accurate description of coloration. Recent expeditions to the Guaporé river provided more adult specimens of $T$. aulopygia, on which the above description is based.

Sexual dimorphism. Based on examination of gonads, $T$. aulopygia attains sexual maturity above $80 \mathrm{~mm}$ SL. In mature females a genital papilla is not evident. The genital papilla of mature males is visible, with a thick skin flap around the deferent duct. The anal fin of mature males (Fig. 9) is strongly modified, with the three unbranched and first two branched rays enlarged and thickened. The first unbranched anal-fin ray is immediately preceded by a tegumentary keel. The second unbranched ray is intermediate in size between the neighboring first and third rays. The third unbranched ray is the longest, forming a minute pointed fin tip (Fig 9, uiii); distal segments are smaller, and antrorsely curved (Fig. 9, ac). The first branched ray is slightly curved towards the fin tip, bearing retrorsely curved distal segments (Fig. 9, rc). The fourth and fifth branched rays are shorter, forming a central notch in distal margin of the anal fin. The posterior branched rays are normally developed and not reduced.

The hemal spines interdigitating with anal-fin pterygiophores are thick in males; but those hemal spines are undifferentiated in females. Caudal-fin lobes are of comparable length in mature females, whereas upper lobe is more elongated in mature males.

Specimens of T. aulopygia historically housed in collections are mostly juveniles, with only one syntype bearing a modified anal fin. Information on male anal-fin morphology was improved by recent captures of adult specimens in the Amazon basin.

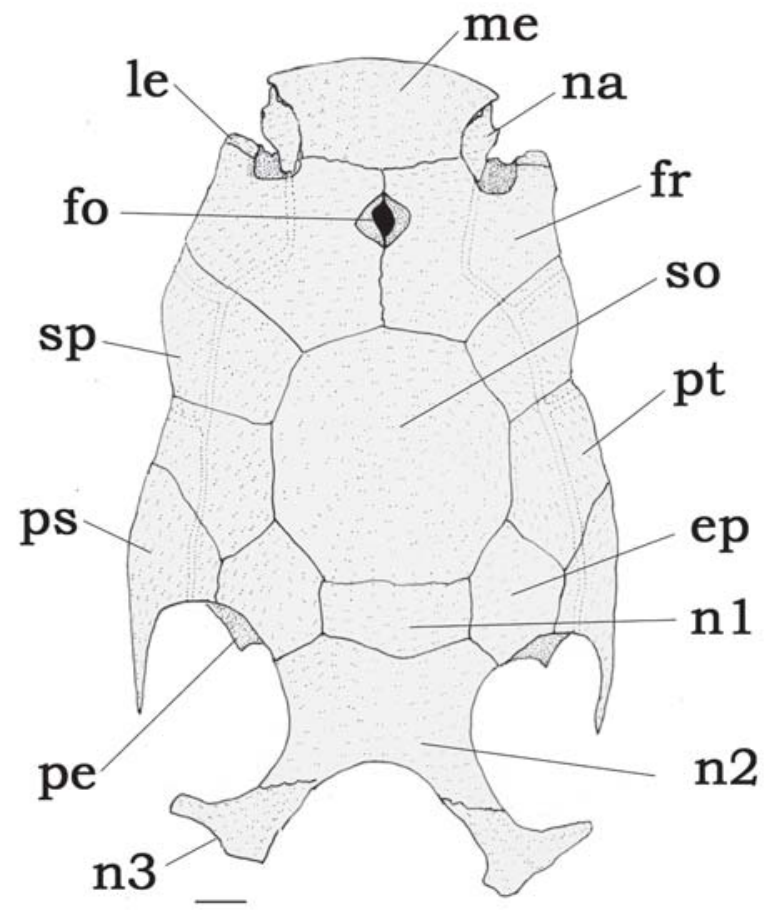

Fig. 8. Neurocranium of Tatia aulopygia, INPA 11080, 80.0 mm SL. Dorsal view. Abbreviations: ep, epioccipital; fo, single cranial fontanel, fr, frontal; le, lateral ethmoid; me, mesethmoid; na, nasal; n1, first nuchal plate, n2; second nuchal plate; n3, third nuchal plate; pe, posterior epioccipital process; ps, posttemporal-supracleithrum; pt, pterotic; so, supraoccipital; sp, sphenotic. Scale bar $=1.0 \mathrm{~mm}$. 
Distribution. Tatia aulopygia occurs in the Madeira river drainage of the Amazon basin. Most records are from upper reaches, in the Guaporé and Mamoré rivers (Fig. 6).

Remarks. A short cranial fontanel, limited to the frontal in $T$. aulopygia, is unique among known Tatia species. In specimens less than $60 \mathrm{~mm} \mathrm{SL}$, however, the cranial fontanel is larger, its opening extends between the mesethmoid and frontals (exemplified by MNHN 1988-994). An ontogenetic shift may occur, as adult specimens have a much reduced opening. A reduced cranial fontanel is found in adult Centromochlus perugiae and C. romani, but in these species the opening is contained by the mesethmoid and frontal (see Soares-Porto, 1998, fig. 4 for comparison).

Tatia aulopygia is somewhat similar in color pattern to three congeners: T. neivai, T. dunni, and T. intermedia. All three species also have the caudal fin with spots or vertical bars, with $T$. aulopygia most closely resembling $T$. neivai. Diagnostic features aside, T. aulopygia is further distinguished from $T$. neivai by having a large first nuchal plate (Fig. 8, vs. reduced in T. neivai). Tatia aulopygia is further distinguished from $T$. dunni by having a shallower snout, depth $41.5-45.9 \%$ HL (vs. 47.0-51.8\% in T. dunni). Tatia aulopygia is further distinguished from $T$. intermedia by a narrower interorbital distance, 53.2-58.9\% HL (vs. 60.1-63.6\% HL in T. intermedia).

Material examined. 17 specimens (21.8-159.0 mm SL). Syntypes. Brazil: NMW 47331, 1 (50.0 mm SL) and NMW 47333, 1 (55.0 mm SL), Guaporé river (syntypes of Centromochlus aulopygius). Non-type specimens. Bolivia: Beni: AMNH 39818, 2 (25.8-27.8 $\mathrm{mm}$ SL), Itenez river; INHS 37034, 1 (75.2 mm SL), Matos river, Apere river drainage, Amazon basin; MNHN 1988-994, 1 (56.3 mm SL) (R), Mamoré river drainage; UMMZ 204834, 1 (24.6 mm $\mathrm{SL})$, Baures river, about $500 \mathrm{~m}$ upstream from mouth of Itenez

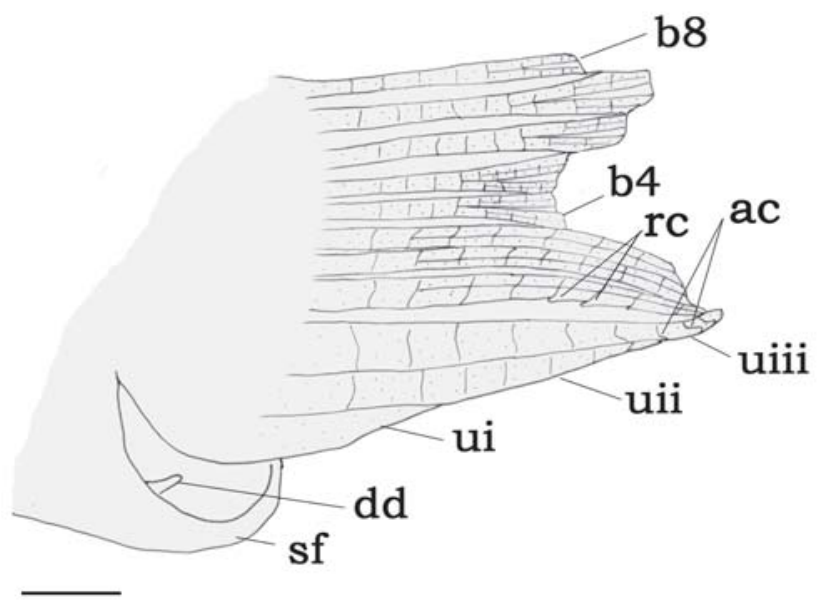

Fig. 9. Male modified anal fin of Tatia aulopygia, INPA 11080, $80.0 \mathrm{~mm}$ SL. Left side lateral view. Abbreviations: ac, antrorsely curved denticulation; $\mathbf{b 4}$, branched fourth ray; $\mathbf{b 8}$, branched eighth ray; dd, deferent duct; rc, retrorsely curved denticulation; sf, skin flap; ui, unbranched first ray; uii, unbranched second ray; uiii, unbranched third ray. Scale bar $=1.0 \mathrm{~mm}$. river. Brazil: Amazonas: ZMA 114.280, 2 (39.6-46.8 mm SL) (R), Madeira river drainage at Humaitá. Rondônia: FMNH 58015, 3 (21.8-43.8 mm SL), Guaporé river in Maciel; INPA 11078, 1 (76.2 $\mathrm{mm} \mathrm{SL})$, INPA 11079, 1 (159.0 mm SL) and INPA 11080, 3, $1 \mathrm{CS}$ (80.0-104.6 mm SL) Guaporé river.

\section{Tatia boemia Koch \& Reis, 1996}

Fig. 1, 10-12

Tatia boemia Koch \& Reis, 1996: 86, fig. 2 [type locality: Brazil, Rio Grande do Sul, Esmeralda, Pelotas river, road Anita Garibaldi to Pinhal da Serra]. Burgess \& Finley, 1996:166 [reference]. Soares-Porto, 1998: 333 [citation]. Ferraris, 2003:476 [checklist]. Ministério do Meio Ambiente, 2004: 140 [endangered species]. Ferraris, 2007: 77 [checklist].

Diagnosis. Tatia boemia is distinguished from other species of Tatia by its unique color pattern of dorsum and dorsolateral sides greyish-brown with small dark chromatophores. Chromatophores become sparse and faint towards the ventral portion of the body ( $c f$. Koch \& Reis, 1996). The species is also distinguished by the following combination of characters: nasal ossified with wide medial flanges partially sutured to lateral border of mesethmoid; pectoral fin with four branched rays; ribs attached to consecutive post-Weberian vertebrae; with two vertebrae alternatingly unribbed and ribbed (Fig. 1). Additional features useful for distinguishing species include: first nuchal plate somewhat elliptical to rounded; eye 17.4$22.8 \% \mathrm{HL}$; caudal-fin lobes of equal length in mature females, upper lobe slightly elongated in mature males; number of vertebrae 34.

Description. Measured adult specimens 52.4-64.5 mm SL; morphometric data presented in Table 3. Body slim, head slightly depressed dorso-ventrally. Head large, robust, outline of head in dorsal view elliptic, broader than long. Dorsal outline of trunk from dorsal-fin base to caudal peduncle gradually compressed posteriorly. Lateral profile of head from snout tip to above opercular margin slightly convex to pectoral-fin insertion. Ventral profile of head and abdomen flat. Ventral profile of body concave posterior to anal fin.

Head integument thin, cranial roof visible; well-developed adipose eye lid; eye latero-dorsally located in anterior portion of head; mouth terminal, upper lip extended posterolaterally as well-developed fleshy rictal fold; snout margin rounded; anterior nostril tubular, located on anterior border of snout, above lip; posterior nostril large, rounded, limited by small skin flap; transverse distance between anterior nostrils slightly shorter than distance between posterior ones. Maxillary barbel moderate in size, extending beyond posterior tip of postcleithral process, reaching vertical through middle of dorsal fin; four mental barbels, tips not reaching pectoral-fin base, arranged in arc along ventral surface of jaw; inner mental barbel about 50.0-61.0\% length of outer mentals. Postcleithral process well developed, almost reach- 


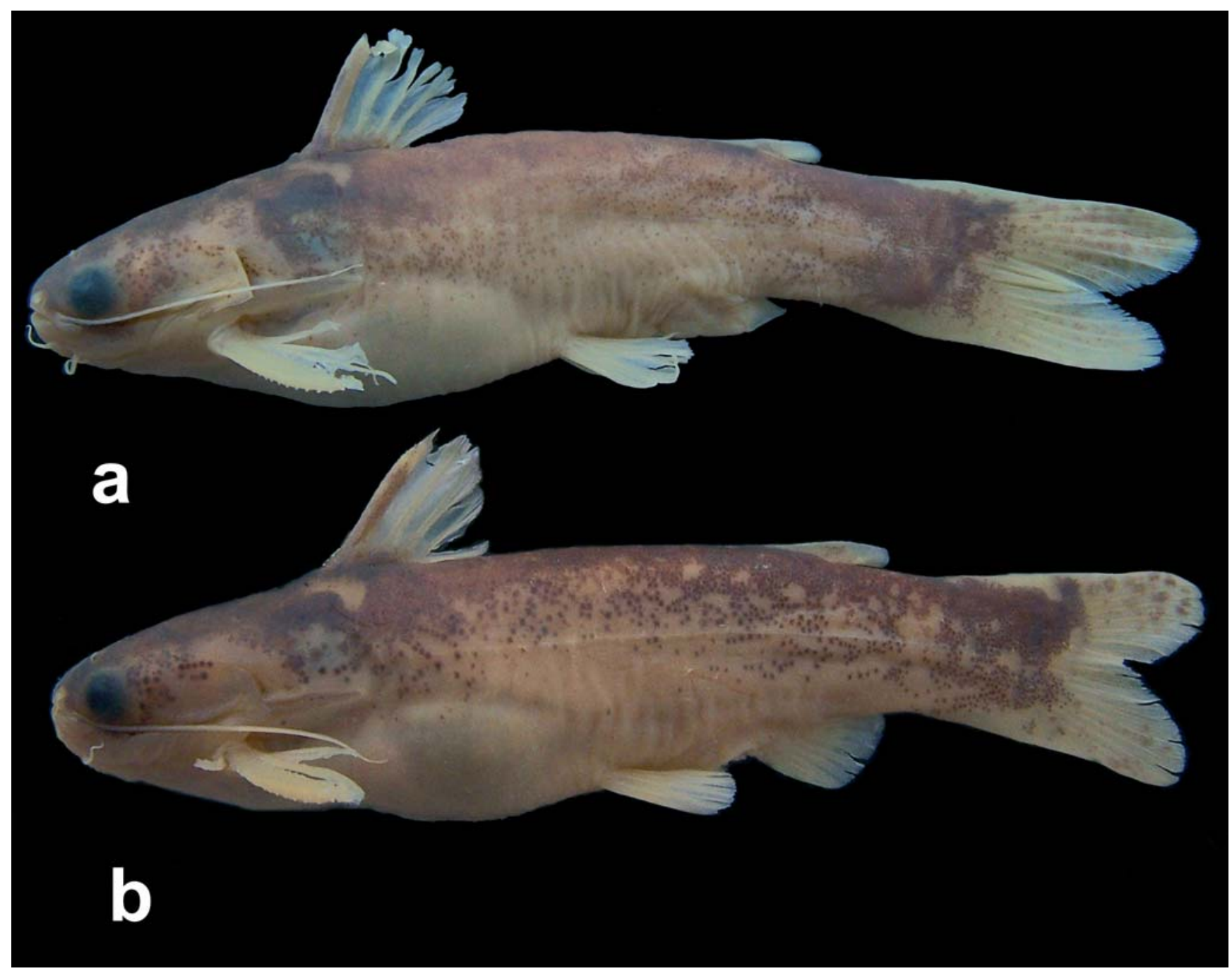

Fig. 10. Tatia boemia, (a) MZUSP 47921, paratype, male, 64.5 mm SL. (b) MZUSP 47921, paratype, female, 52.4 mm SL, rio Pelotas, Rio Grande do Sul State, Brazil.

ing vertical through middle of dorsal fin. Caudal peduncle deep, its depth about 13.6-14.2\% SL.

Rostral border of cranium broad with large mesethmoid; premaxilla underneath with synchondral articulation; cranial fontanel narrow, elliptical, bounded by mesethmoid and frontal (Fig. 11); nasal ossified, with medial flanges partially sutured to lateral margin of mesethmoid; autopalatine tubular, oriented obliquely to longitudinal axis of body; maxilla small, shorter than autopalatine; prevomer expanded with well developed arrow-shaped lateral processes; jaws of equal size; premaxilla and dentary with three to four rows of conical teeth; first nuchal plate somewhat elliptical; second nuchal plate laterally concave, partially in contact or not with supraoccipital; third nuchal plate relatively straight, projected laterally. Epioccipital process small.

Suspensorium, hyoid arch, branchial skeleton and opercular bones as in generic description. Suprapreopercle present as short canal bone. Six branchiostegal rays articulated with hyoid arch: four with anterior ceratohyal and two with posterior ceratohyal. Branchial skeleton as for genus. Basibranchial
2 forming osseous rod with broad cartilaginous anterior tip, separated from shorter basibranchial 3.

Six infraorbital bones in complete series. Infraorbital 1 broad, with moderately developed ventro-lateral process, around anterior border of eye; remaining infraorbitals thin, reduced to canalicular portions. Infraorbital 2 smallest, close to infraorbital 1 , followed by three elongate canal bones, forming bottom orbital rim; infraorbital 5 small, forming posterior orbit. Lateral line on body with ossified canal bones until vertical through pelvic fin.

Dorsal fin I,5 ( $n=8)$; dorsal-fin spine with 13-16 antrorse serrations along entire anterior margin; posterior margin smooth. Pectoral fin I,4 ( $\mathrm{n}=8)$; pectoral-fin spine with 19-22 antrorse serrations along anterior margin, small serrations close to spine base; $14-15$ retrorse serrations along posterior margin; serrations along both margins progressively larger towards spine tip. Pelvic-fin i,5 ( $n=8)$, margin rounded. Adipose fin large, origin on vertical through middle anal-fin base. Anal fin iii,7 $(n=8)$; anal-fin pterygiophores in eight rod-like proximal radials and seven cartilaginous distal radials (Fig. 1). 


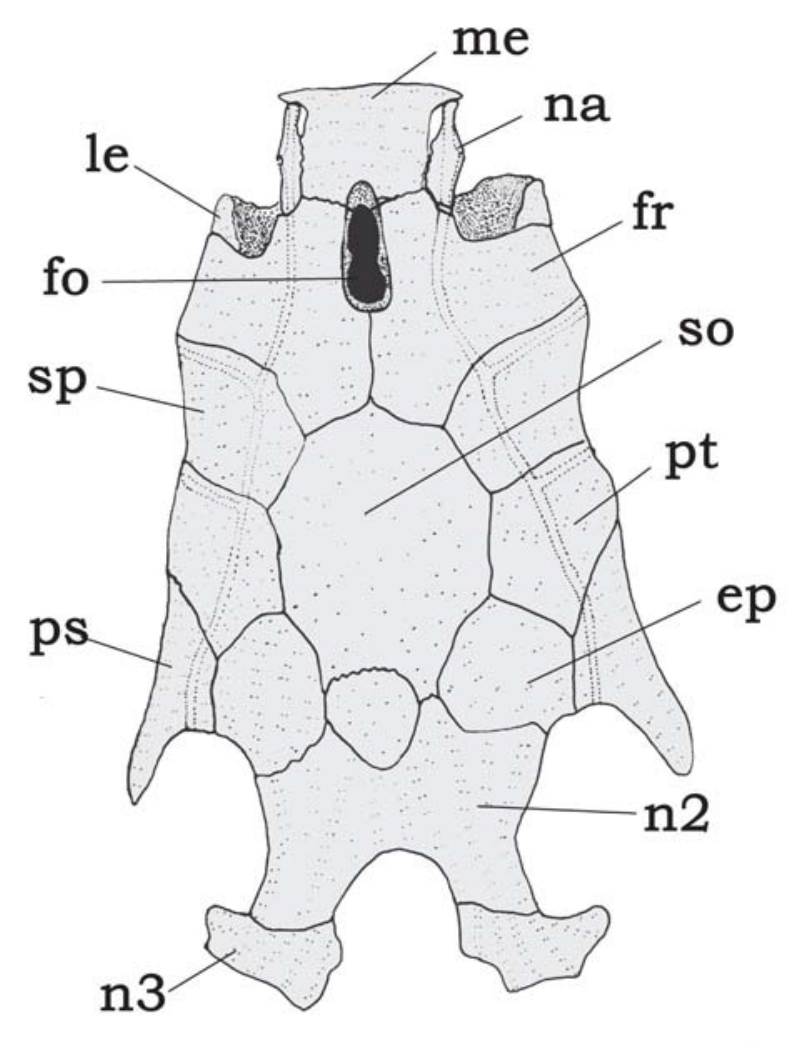

Fig. 11. Neurocranium of Tatia boemia, MCP 12949, paratype, 59.9 mm SL. Dorsal view. Abbreviations: ep, epioccipital; fo, single cranial fontanel; fr, frontal; le, lateral ethmoid; me, mesethmoid; na, nasal; n2; second nuchal plate; n3, third nuchal plate; ps, posttemporal-supracleithrum; pt, pterotic; so, supraoccipital; sp, sphenotic. Scale bar $=1.0 \mathrm{~mm}$.

Caudal fin forked, lobes with rounded tips, $8+9$ principal rays, 19-21 upper procurrent, 19-20 lower procurrent rays $(n=8)$. First nine post-Weberian vertebrae ribbed. Tenth vertebrae correspond to a gap, with no ribs attached, plus one rib attached to $11^{\text {th }}$ vertebrae (Fig. 1). Post-Weberian vertebrae 34 $(n=3)$.

Color in alcohol. Color pattern diagnostic within Tatia, as stated in the original description by Koch \& Reis (1996): Dorsal surface of head, back and upper sides, greyish-brown with many chromatophores surrounding small lighter (depigmented) areas; sides becoming paler ventrally as chromatophores become progressively more widely spaced; lower sides and ventral surfaces yellowish. Dorsal-fin spine dark. Lips, anterior nostril and chin whitish. Barbels, posterior part of nuchal shield, pectoral, pelvic, anal, and adipose fins unpigmented. Caudal fin largely pale with small dark spots.

Sexual dimorphism. Based on examination of gonads, $T$. boemia attains sexual maturity above $52.4 \mathrm{~mm} \mathrm{SL}$. In mature females a genital papilla is not evident. In mature males a genital papilla is visible, thick, with a short deferent duct. The
Table 3. Morphometric data for Tatia boemia $. \mathrm{SD}=$ standard deviation.

\begin{tabular}{lcccc}
\hline & Range & Mean & SD & N \\
\hline Standard length & $52.4-64.5$ & 56.6 & & 5 \\
& Percents of standard length & & & \\
Body depth & $21.7-26.3$ & 23.1 & 1.45 & 5 \\
Body width & $18.6-20.0$ & 19.2 & 0.47 & 5 \\
Caudal peduncle depth & $13.6-14.2$ & 13.9 & 0.46 & 5 \\
Caudal peduncle length & $23.5-26.0$ & 24.8 & 1.82 & 5 \\
Predorsal length & $29.7-32.6$ & 31.1 & 0.91 & 5 \\
Preanal length & $71.2-74.8$ & 72.8 & 1.82 & 5 \\
Prepelvic length & $52.2-57.2$ & 54.0 & 1.71 & 5 \\
Dorsal origin to pectoral origin & $21.3-24.5$ & 22.4 & 1.07 & 5 \\
Dorsal origin to pelvic origin & $31.0-36.7$ & 34.0 & 1.86 & 5 \\
Pectoral origin to pelvic origin & $35.3-39.6$ & 37.2 & 1.98 & 5 \\
Prepectoral length & $18.6-23.3$ & 21.0 & 1.59 & 5 \\
Dorsal-fin base length & $8.8-10.7$ & 9.6 & 0.56 & 5 \\
Adipose-fin base length & $11.0-13.0$ & 12.0 & 0.70 & 5 \\
Anal-fin base length & $3.7-10.7$ & 7.5 & 2.85 & 5 \\
Dorsal-fin spine length & $15.0-18.7$ & 16.1 & 1.17 & 5 \\
Pectoral-fin spine length & $19.8-21.8$ & 21.5 & 0.75 & 5 \\
Postcleithral process length & $16.6-19.4$ & 18.5 & 0.85 & 5 \\
First branched pelvic-fin ray & $9.9-14.5$ & 12.9 & 1.50 & 5 \\
Longest anal fin ray & $6.5-10.4$ & 8.7 & 1.50 & 5 \\
Maxillary barbell length & $30.5-36.1$ & 33.4 & 1.78 & 5 \\
Outer mental barbel length & $7.8-10.3$ & 9.0 & 0.96 & 5 \\
Mental barbel length & $4.3-6.1$ & 5.2 & 0.56 & 5 \\
Head length & $22.0-25.2$ & 23.2 & 1.21 & 5 \\
& & & & \\
Head width & $74.1-78.9$ & 76.5 & 1.98 & 5 \\
Snout depth & $51.4-55.6$ & 53.0 & 1.81 & 5 \\
Interorbital distance & $52.9-58.2$ & 55.5 & 1.95 & 5 \\
Left internarial width & $23.1-24.6$ & 24.1 & 0.69 & 5 \\
Anterior internarial distance & $35.9-37.3$ & 36.4 & 0.66 & 5 \\
Posterior internarial distance & $39.4-44.7$ & 41.5 & 1.99 & 5 \\
Snout length & $37.7-43.6$ & 39.9 & 1.98 & 5 \\
Orbital diameter & $17.4-22.8$ & 20.7 & 1.79 & 5 \\
Mouth width & $39.0-43.2$ & 41.2 & 1.89 & 5 \\
\hline & & & &
\end{tabular}

anal fin of the mature males (Fig. 12) is strongly modified with the three unbranched and first branched rays enlarged and thickened. The first unbranched ray is non-segmented and shortest, about half-the length of second unbranched ray (Fig. 12). First unbranched anal-fin ray is immediately preceded by a tegumentary keel (Fig. 12, tk). The second unbranched ray has an intermediate size between the neighboring first and third rays. Third unbranched and first branched are the longest rays forming a fin tip (Fig. 12, uiii). Third unbranched with the three distal segments smaller, antrorsely curved (Fig. 12, ac). First branched ray with four distal segments retrorsely curved (Fig. 12, rc). The posterior branched rays are progressively shorter.

The hemal spines 15-17 are associated with anal-fin pterygiophores in males and become thick during maturity. Female hemal spines 15-18 are associated with pterygiophores and undifferentiated (Fig. 1).

There is a discrete sexual dimorphism regarding the caudal-fin margin in mature males of T. boemia. The upper caudal-fin lobe is slightly elongate, about $10.0 \%$ longer than the lower lobe, whereas mature females have equal lobes.

Distribution. Tatia boemia is endemic to upper reaches of the Uruguay river drainage (Fig. 6). It is the most southernly dis- 
tributed species of Tatia. Together with T. neivai both are the only species inhabiting the La Plata basin (Koch \& Reis, 1996).

Remarks. Tatia boemia is the only auchenipterid catfish listed in Brazil as an endangered species (Ministério do Meio Ambiente, 2004). As it is a typically nocturnal catfish, the local people call $T$. boemia under the common name "boa noite", meaning good night (Walter R. Koch, pers. comm.).

In T. boemia the first (anterior) nuchal plate is variable in size. First nuchal plate is sometimes assymmetrical, permiting contact between supraoccipital and second nuchal plate (as in Fig. 11), or symmetrical, bordered by supraoccipital and second (middle) nuchal plate. We observed variation in first nuchal plate size in other auchenipterid species, such as Centromochlus perugiae and Glanidium leopardus. Anterior (first) nuchal plate either fully developed or reduced is reported in a few doradid species as Oxydoras niger and Doras fimbriatus (Birindelli et al., 2007: 680), and the species are considered polymorphic regarding this character. Polymorphism seems to be also the case in the above mentioned auchenipterids including $T$. boemia.

Tatia boemia is presumed to be sister to T. neivai, both sharing the presence of a single vertebrae without ribs preceding the last ribbed vertebrae (character 17, fig. 14 of SoaresPorto, 1998). This ribless vertebra (number 9 in T. neivai, 10 in T. boemia) has each transverse process with a reduced costal facet. The last rib pair is small and attached to the hemal arch of vertebra 10 (T. neivai) or 11 (T. boemia). In all other Tatia species the ribs are attached to consecutive post-Weberian vertebrae.

Material examined. 8 specimens (33.1-64.1 mm SL). Paratypes. Brazil: Rio Grande do Sul: MCP 12949, 6, 1 CS, (33.1-61.1 mm SL) and MZUSP 47921, 2 (52.4-64.5 mm SL) (R), Esmeralda, Pelotas river, road Anita Garibaldi to Pinhal da Serra (paratypes of Tatia boemia).

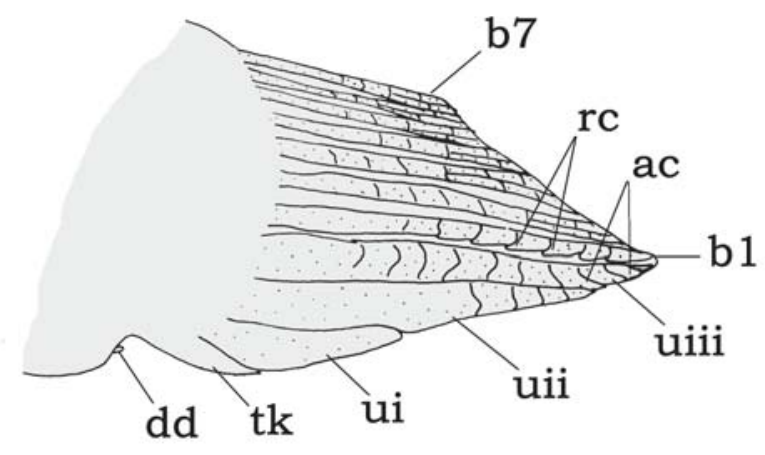

Fig. 12. Male modified anal fin of Tatia boemia, MCP 12949 , paratype, $59.9 \mathrm{~mm}$ SL. Left side lateral view. Abbreviations: ac, antrorsely curved denticulation; b1, branched first ray; b7, branched seventh ray; dd, deferent duct; rc, retrorsely curved denticulation; tk, tegumentary keel; ui, unbranched first ray; uii, unbranched second ray; uiii, unbranched third ray. Scale bar $=1.0 \mathrm{~mm}$.

\section{Tatia brunnea Mees, 1974}

Figs. 13-15

Tatia brunnea Mees, 1974: 84, fig. 21 [type locality: Suriname, Compagnie stream]. Mees, 1983: 46 [French Guiana: streams Balaté \& Awahakiki]. Mees, 1985: 242 [Suriname, Loë stream]. Mees, 1988: 411 [French Guiana: Sinnamary, Petit-Saut]. Soares-Porto, 1998: 331-350 [citation]. Kobayagawa, 1991:104 [reference]. Wallace, 2002: 297 [Negro river]. Ferraris, 2003:475 [checklist]. Ferraris, 2007: 77 [checklist].

Tatia cf. intermedia. Mees, 1983: 46, fig. 2 [Blanche stream, Acarouany, French Guiana]. Le Bail et al., 2000:68 [reference].

Tatia aulopygia. Goulding et al., 1988: 180 [Negro river].

Tatia sp. cf. brunnea. Burgess, 1989: 595, pl. 113 [tropical South America].

Tatia intermedia. Burgess, 1989: 242 [Guianas]. Soares-Porto, 1998: 333 [citation].

Diagnosis. Tatia brunnea is distinguished from its congeners by the male anal fin with sharp pointed tip; the first unbranched anal-fin ray divided into 3-4 segments; and the last branched ray reduced (Fig. 15). Tatia brunnea differs from most of its congeners, except $T$. aulopygia, $T$. intermedia and $T$. gyrina by having a wide mouth, width $54.0-59.7 \% \mathrm{HL}$ (vs. 39.0-53.3\% HL). Additional characteristics for recognition of T. brunnea are diagnostic in combination: Nasal ossified with wide medial flanges partially sutured to lateral margin of mesethmoid; ribs 9-10; post-Weberian vertebrae 34-36. Additional features useful for distinguishing T. brunnea include details in coloration, such as: border of mouth whitish, contrasting with dark head; posterior border of nuchal shield usually whitish or pale; pectoral-fin spine usually with transverse bands; and caudal fin usually whitish with scattered dark brown blotches.

Description. Measured adult specimens 54.6-97.4 mm SL; morphometric data presented in Table 4. Body deep, head depressed dorso-ventrally. Head robust, outline of head in dorsal view somewhat elliptic, broader than long. Trunk from dorsal-fin base to caudal peduncle gradually compressed laterally. Outline of head in dorsal view from snout tip to opercular margin slightly convex until pectoral-fin insertion. Ventral profile of head and abdomen slightly convex. Ventral profile of body gently curved, concave behind anal-fin origin.

Head integument thin, cranial roof visible; well-developed adipose eye lid; eye latero-dorsally located in anterior portion of head; mouth terminal, upper lip extended posterolaterally as well-developed fleshy rictal fold; anterior nostril tubular, located on anterior border of snout, above lip; posterior nostril large, rounded, limited by small skin flap; transverse distance between anterior nostrils proportionally the same distance between posterior ones in HL. Maxillary barbel short, extending close to posterior tip of postcleithral process, sometimes larger; mental barbels short, tips not reach- 


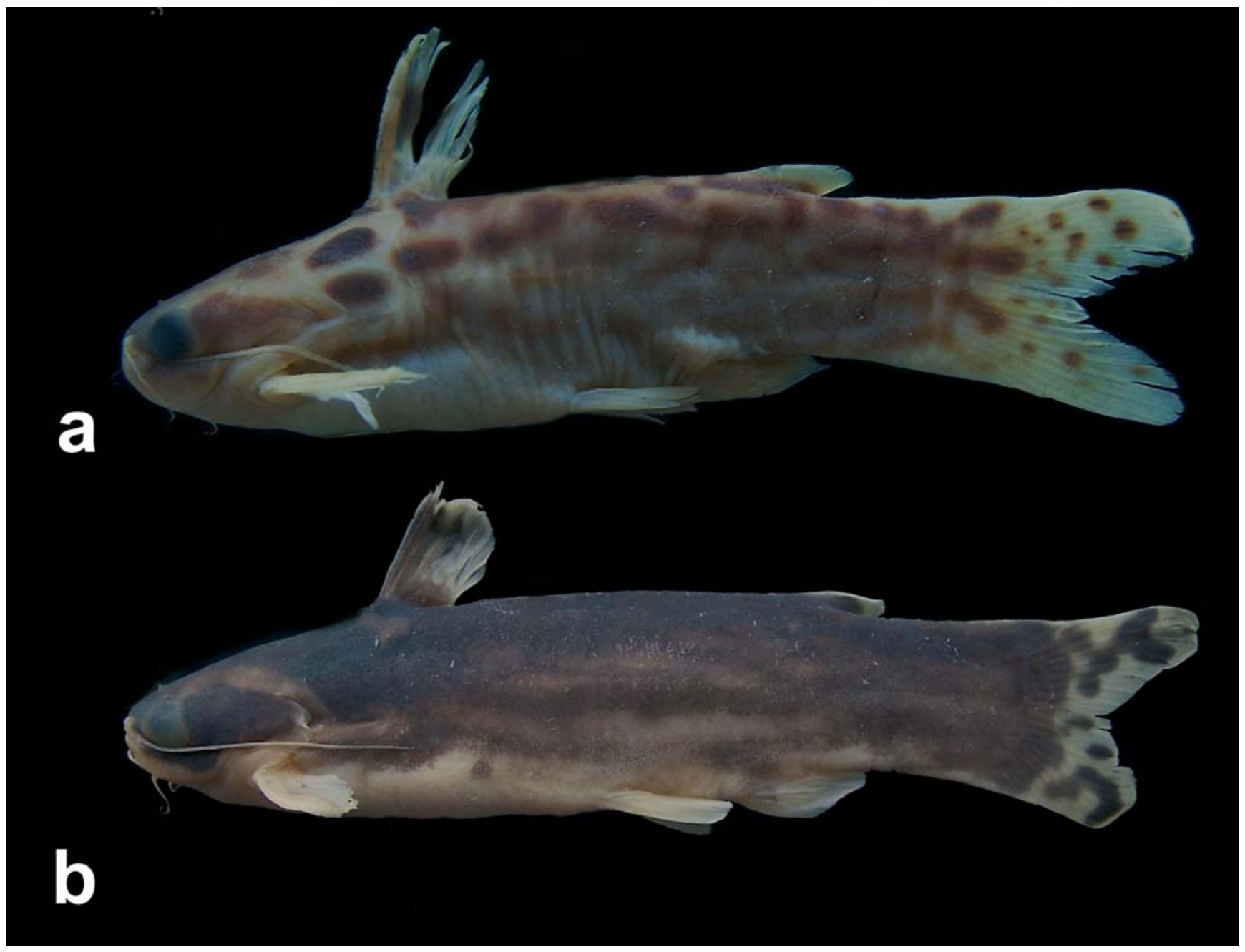

Fig. 13. Tatia brunnea. (a) AMNH 58390, paratype, male, $54.6 \mathrm{~mm}$ SL, Kamaloe Stream, Suriname. (b) MZUSP 81250 , female, $52.4 \mathrm{~mm}$ SL, Tiquié river, Amazonas State, Brazil.

ing pectoral-fin base, arranged in arc along ventral surface of jaw; inner mental barbel about 55.0-65.0\% length of outer mental barbel. Postcleithral process almost reaching vertical through middle or end of dorsal fin. Caudal peduncle deep, depth about $14.3-17.4 \%$ SL.

Rostral border of cranium broad with mesethmoid as long as broad; premaxilla underneath with synchondral articulation; cranial fontanel elliptical, bounded by mesethmoid and frontal (Fig. 14); nasal ossified with narrow medial flanges, not sutured to mesethmoid in immature specimens, but sutured to mesethmoid in adults; autopalatine tubular, oriented obliquely to longitudinal axis of body; maxilla about same size of autopalatine; prevomer expanded anteriorly with well developed arrow-shaped lateral processes; jaws of equal size; premaxilla and dentary with three to four rows of conical teeth. First nuchal plate trapezoid; second nuchal plate slightly concave along lateral margins; third nuchal plate curved, projected laterally, with broad tip. Epioccipital process very small.

Suspensorium, hyoid arch, branchial skeleton and opercular bones as in generic description. Suprapreopercle present as short canal bone. Five to six branchiostegal rays articu- lated with hyoid arch: three or four with anterior ceratohyal and two with posterior ceratohyal; last two flattened and expanded; basibranchial 2 forming osseous rod with broad cartilaginous anterior tip, separated from shorter basibranchial 3 .

Five infraorbital bones in incomplete series. Infraorbital 1 thin with short ventro-lateral process; remaining infraorbitals thin, reduced to canalicular portions; infraorbital 2 smallest, followed by non-ossified portion of canal below eye and by two posterior canal bones much close to sphenotic, forming posterior orbital rim. Lateral line on body with ossified canal bones posteriorly to vertical of pelvic fin origin.

Dorsal fin I,5 ( $\mathrm{n}=24)$; dorsal-fin spine with 13-14 antrorse serrations along anterior margin; posterior margin smooth. Pectoral fin I,4-5 ( $\mathrm{n}=24)$; pectoral-fin spine with 19-21 antrorse serrations along anterior margin; 12-14 retrorse serrations along posterior margin; serrations along both margins progressively larger towards spine tip. Pelvic-fin i,5 (n=24); margin rounded. Adipose fin large, origin on vertical through middle anal-fin base. Anal fin iii, 7, rarely iii, $8(\mathrm{n}=24)$; anal-fin pterygiophores in seven to eight rod-like proximal radials and six to seven cartilaginous distal radials. Caudal fin forked, 
lobes with rounded tips, 8+9 principal rays, 18-22 upper procurrent, 14-20 lower procurrent rays $(n=24)$. Pleural ribs 910 , attached to consecutive vertebrae. Post-Weberian vertebrae $34-36(n=13)$.

Color in alcohol. Color pattern considered as diagnostic in original description by Mees (1974: 84): color dark brown in fresh specimens, with vague pale areas; older specimens with wavy longitudinal bands and dots of dark brown, alternating with pale brown areas; dorsal shield usually distinctly paler than body; pectoral, dorsal and adipose fins spotted with brown, dorsal fin largely dark brown; ventrals and anal fins hyaline, caudal fin hyaline with large irregular blackish brown dots. Contour of lips and anterior nostrils usually whitish. Pectoral fin usually with transversal dark bands. Live coloration in $T$. dunni aquarium specimen illustrated by Burgess (1989: pl. 113).

Large preserved specimens (over $90 \mathrm{~mm}$ SL) with diminished color pattern. These individuals bear spots, blotches or even stripes generally much less defined.

Color variation. Regional variation in pigmentation was observed in T. brunnea (as exemplified in Fig. 13). Suriname specimens attain smaller adult size (50-72 $\mathrm{mm} \mathrm{SL})$ and have

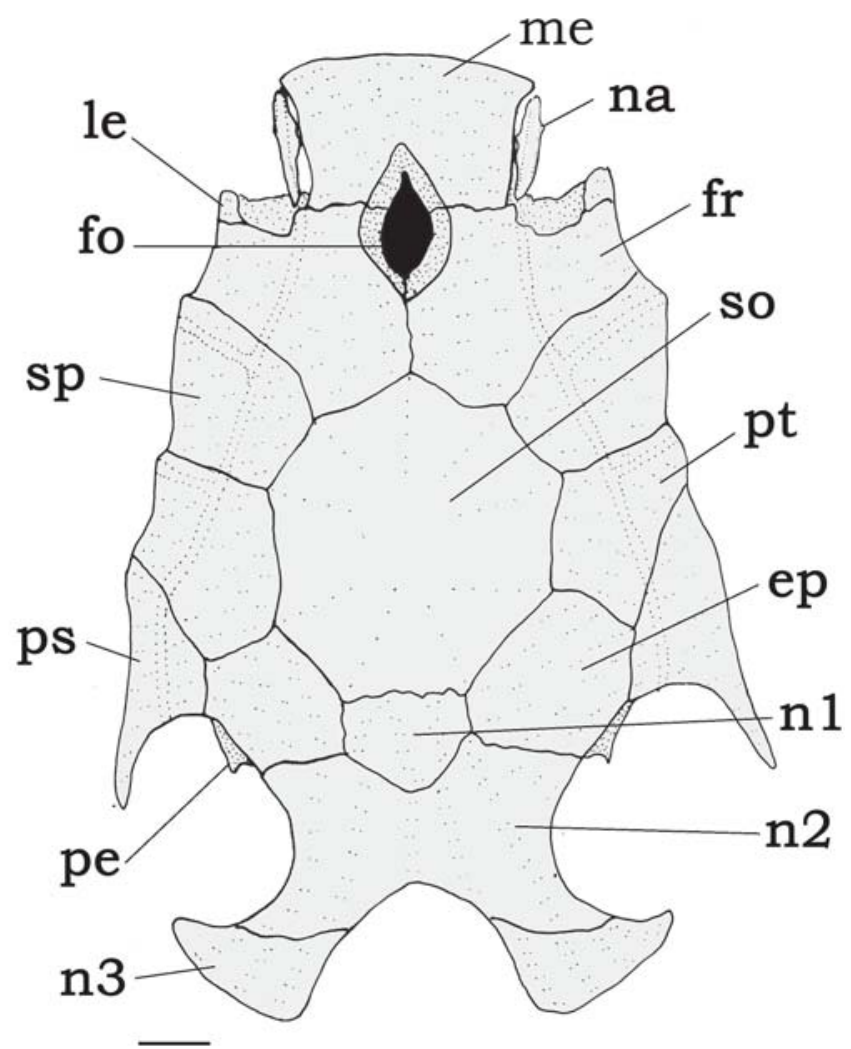

Fig. 14. Neurocranium of Tatia brunnea, RMNH 26198, paratype, $39.1 \mathrm{~mm}$ SL. Dorsal view. Abbreviations: ep, epioccipital; fo, single cranial fontanel, fr, frontal; le, lateral ethmoid; me, mesethmoid; na, nasal; n1, first nuchal plate, n2; second nuchal plate; n3, third nuchal plate; pe, posterior epioccipital process; ps, posttemporal-supracleithrum; pt, pterotic; so, supraoccipital; sp, sphenotic. Scale bar $=1.0 \mathrm{~mm}$. irregular stripes or blotches along body (Fig. 13a). Specimens from Negro river attain larger size (60-97.4 mm SL), and are mottled with dark and light brown areas (Fig. 13b). Some are completely dark brown along sides of body, with caudal-fin lobes irregularly striped (MZUSP 81139).

In the headwaters of upper Negro river, draining the Cerro de Neblina Mountains, the catfishes attain the largest size observed for the species, $116 \mathrm{~mm} \mathrm{SL}$, and have large irregular stripes on sides of body. A single population of T. brunnea was found in central Amazon, in the Trombetas river. These fishes have dark brown bands at the center of each caudal-fin lobe, a coloration pattern also observed in some specimens from the Negro river (INPA 15989).

Sexual dimorphism. Based on examination of gonads, $T$. brunnea attains sexual maturity above $54.6 \mathrm{~mm}$ SL. The upper Amazon population, however, is found to consist of larger individuals and maturation was attained above $70 \mathrm{~mm} \mathrm{SL}$. In mature females a genital papilla is not evident. The genital papilla of mature male is visible, with an emergent deferent duct. The anal fin of mature males (Fig. 15) is strongly modified, with three thickened unbranched rays. The first unbranched ray is the shortest ray, about three-quarter length of second unbranched ray. First unbranched ray is segmented,

Table 4. Morphometric data for Tatia brunnea. $\mathrm{SD}=$ standard deviation.

\begin{tabular}{|c|c|c|c|c|}
\hline & Range & Mean & SD & $\mathrm{N}$ \\
\hline Standard length & $54.6-97.4$ & 62.1 & & 24 \\
\hline \multicolumn{5}{|c|}{ Percents of standard length } \\
\hline Body depth & $15.7-23.8$ & 19.6 & 1.75 & 24 \\
\hline Body width & $17.5-23.4$ & 20.0 & 1.46 & 24 \\
\hline Caudal peduncle depth & $14.3-17.4$ & 15.5 & 1.31 & 24 \\
\hline Caudal peduncle length & $24.2-29.4$ & 27.0 & 1.55 & 24 \\
\hline Predorsal length & $25.2-34.8$ & 31.2 & 1.64 & 24 \\
\hline Preanal length & $63.1-71.4$ & 66.4 & 2.22 & 24 \\
\hline Prepelvic length & $46.2-53.4$ & 50.2 & 1.65 & 24 \\
\hline Dorsal origin to pectoral origin & 20.4-24.7 & 22.3 & 1.23 & 24 \\
\hline Dorsal origin to pelvic origin & $26.6-33.2$ & 29.9 & 1.72 & 24 \\
\hline Pectoral origin to pelvic origin & $30.1-37.3$ & 33.4 & 1.59 & 24 \\
\hline Prepectoral length & $18.1-22.8$ & 20.0 & 1.15 & 24 \\
\hline Dorsal-fin base length & $7.8-12.5$ & 9.9 & 1.30 & 24 \\
\hline Adipose-fin base length & $8.4-15.8$ & 11.1 & 1.92 & 24 \\
\hline Anal-fin base length & $4.4-9.4$ & 7.4 & 2.04 & 24 \\
\hline Dorsal-fin spine length & $13.4-22.1$ & 17.4 & 1.82 & 24 \\
\hline Pectoral-fin spine length & $16.8-28.0$ & 23.3 & 2.22 & 24 \\
\hline Postcleithral process length & $15.7-21.8$ & 18.5 & 1.58 & 24 \\
\hline First branched pelvic-fin ray & $10.1-14.9$ & 12.5 & 1.55 & 24 \\
\hline Longest anal fin ray & $5.3-12.5$ & 8.9 & 1.63 & 24 \\
\hline Maxillary barbel length & $28.0-34.0$ & 31.0 & 1.82 & 24 \\
\hline Outer mental barbel length & $7.2-10.5$ & 8.7 & 0.74 & 24 \\
\hline Mental barbel length & $4.3-6.6$ & 5.4 & 0.53 & 24 \\
\hline Head length & $21.0-26.1$ & 23.2 & 1.24 & 24 \\
\hline \multicolumn{5}{|c|}{ Percents of head length } \\
\hline Head width & $86.6-93.4$ & 85.6 & 2.23 & 24 \\
\hline Snout depth & $47.1-51.9$ & 50.5 & 1.38 & 24 \\
\hline Interorbital distance & $54.3-63.9$ & 59.7 & 2.35 & 24 \\
\hline Left internarial width & $19.4-26.2$ & 22.7 & 1.82 & 24 \\
\hline Anterior internarial distance & $38.6-45.2$ & 41.7 & 1.60 & 24 \\
\hline Posterior internarial distance & $36.0-42.9$ & 40.3 & 1.87 & 24 \\
\hline Snout length & $36.1-43.3$ & 37.3 & 2.55 & 24 \\
\hline Orbital diameter & $21.8-26.4$ & 22.8 & 1.80 & 24 \\
\hline Mouth width & $54.0-59.7$ & 55.1 & 3.73 & 24 \\
\hline
\end{tabular}


usually with 3-5 separated dermal segments (lepidotrichia). A segmented first unbranched ray was observed in most Suriname specimens, but not in all, and may be associated to regional differentiation. The first unbranched anal-fin ray is immediately preceded by a tegumentary keel (Fig. 15, tk). The second unbranched ray has an intermediate size between the neighboring first and third rays. Third unbranched is the longest ray forming a long sharp pointed fin tip together with the first branched (Fig. 15, uiii). Third unbranched distal segments are antrorsely curved (Fig. 15, ac). First branched ray bearing retrorsely curved distal segments (Fig. 15, rc). Posterior branched rays are normally developed and progressively shorter; with last ray reduced (Fig. 15, b7).

Hemal spines 16-19 interdigitate with the anal-fin pterygiophores; hemal spines 15-17 or 16-18 are thickened in mature males, but undifferentiated in females. The caudal-fin lobes have the same length in mature females, whereas upper lobe is elongated in mature males.

Distribution. Tatia brunnea was described from the Suriname and Marowijne-Maroni river basins in Suriname. It was recorded in French Guiana from the Maroni and Sinnamary river basins. In Brazil it occurs in the Negro river drainage and at a single locality in Central Amazon basin, in the Trombetas river drainage (Fig. 6).

Remarks. Until recently, T. brunnea was thought to be restricted to Suriname (Ferraris, 2003), although it was previously recorded in the Negro river as well (Wallace, 2002). The overall coloration of $T$. brunnea ressembles that of $T$. dunni, from upper Amazon. Details in coloration of caudal fin helps to distinguish between these two species, as in T. brunnea the caudal fin is whitish with dark spots or bands ( $v s$. darker with whitish blotches in $T$. dunni). Additional distinctions include a wide head in T. brunnea, 86.6-93.4\% HL (vs. narrow in T. dunni, 76.0-80.1\% HL); a wide mouth, 54.0-59.7\% HL (vs. narrow, 48.1-52.3\% HL); and a male modified anal fin with sharply pointed distal tip ( $v s$. short rounded distal tip). Tatia brunnea occurs in sympatry with $T$. intermedia in some rivers in Suriname and French Guiana and also in the Trombetas river.

Material examined. 128 specimens (16.2-97.4 mm SL). Holotype. Suriname: RMNH 26196, $56.5 \mathrm{~mm} \mathrm{SL}$, Compagnie stream (holotype of Tatia brunnea). Paratypes. Suriname: AMNH 58390, 1 (54.6 mm SL) (R), Kamaloe stream, right margin of Marowijne river. RMNH 26197, 3 (47.6-60.0 mm SL), Compagnie stream; RMNH 26198, 3, 1 CS (35.1-40.3 mm SL), Kwambaolo stream, near dam; ZMA 105.526, 4 (26.5-36.6 mm SL), Gran river, $63 \mathrm{Km}$ south of Affobakka; ZMA 105.860, 1 (41.5 mm SL) (R), Sara stream, about $27 \mathrm{Km}$ south of dam; ZMA 105.849, 7 (27.0-52.2 mm SL) (R), Maka stream, tributary of Lawa river, Marowijne district (paratypes of Tatia brunnea). Non-type specimens: Brazil: Amazonas: ANSP 165747, 2, igarapé Castanho, Negro river; CAS 76790, 2 (70.3-80.2 mm SL), Cuieras river; INPA 14228, 2 (96.997.4 mm SL), Urubu river, igarapé of Gavião, Farm Esteio, Negro river basin; INPA 15989, 1 (66.6 mm SL), Presidente Figueiredo, Urubu river, Negro river basin; INPA 16577, 1 (89.0 mm SL),
Jauaperi river, igarapé Cambina, Negro river basin; MCZ 52670, 2 (28.2-37.0 mm SL), Cuieras river in isolated pool; MZUSP 9352, 1 (18.6 mm SL), Central lake, left margin of Negro river between Camanaú and Apeú rivers; MZUSP 31075, 1 (34.0 mm SL), Negro river, Barcelos, island lake; MZUSP 44126, 1 (38.3 mm SL); MZUSP 44258, 2 (23.4-36.7 mm SL), Negro river, Anavilhanas archipaelago; ZMA 119.949, 1 (58.0 mm SL), Negro river and tributaries; MZUSP 81139, 1 (78.0 mm SL), Tiquié river, between communities of Caruru and Boca de Sal, Negro river drainage; MZUSP 81177, 2 (36.9-59.4 mm SL), Tiquié river, mouth of igarapé Açaí, near São Pedro community, Negro river drainage; MZUSP 81250, 10, 1 CS (44.6-81.7 mm SL), Tiquié river, between communities of São Pedro and Caruru upstream from waterfalls, Negro river drainage; ZMA 119.949, 1 (58.0 mm SL), Negro river and tributaries. Pará: MNRJ 15332, 1 (32.7 mm SL), MNRJ 15333, 1 (44.4 mm SL) and MNRJ 15334, 3, 1 CS (31.1-43.4 mm SL), igarapé Saracazinho, tributary of Batata lake, Porto Trombetas. French Guiana: RMNH 28570, 3 (29.6-50.0 mm SL), Awahakiki river; RMNH 28569, 2 (34.3-41.4 mm SL) and RMNH 28571, 4, 1 CS (25-37 mm SL), Balaté stream; RMNH 30494, 1 (70.0 mm SL), Petit-Saut, Sinnamary. Suriname: AMNH 58391, 2 (65.3-75.4 mm SL), Suriname river near Botopasi; RMNH 27530, 3 (26.7-28.0 mm SL), upper Loë river, tributary of Litani river; RMNH 28568 , 2 (42.5-45.0 mm SL), stream below Acarouany; RMNH 28654, 1 (51.5 mm SL), stream below Bivouac downstream from Lombok waterfalls; RMNH 28655, 1 (54.0 mm SL), tributary at right margin of Nickerie river below Blanche Marie Falls; RMNH 28656, 2 (50.0$81.0 \mathrm{~mm} \mathrm{SL})$, tributary at right margin of Kaboeri stream, Corantjn river basin; RMNH 28658, 2 (45.1-74.0 mm SL), tributary at right margin of Kabalebo river, about $8 \mathrm{Km}$ below Avanavero waterfalls; USNM 226124, 1, stream south of Matapi, Nickerie district; USNM 226125, 5 (16.2-23.3 mm SL), tributary of Corantijn river, north of Tiger Falls, Nickerie district; ZMA 105.831, 3 (34.4-60.2 mm SL), tributary of Nickerie river south of Stondansie Vallen.

\section{Tatia caxiuanensis, new species} Figs. 16-18

Holotype. MPEG 9859, male (32.6 mm SL), Brazil, Pará: município de Melgaço, Estação Científica Ferreira Pena, Curuá river, Caxiuanã, 0144'53"S 51²7'13”W, 1 Nov 1999, R. Barthem and team.

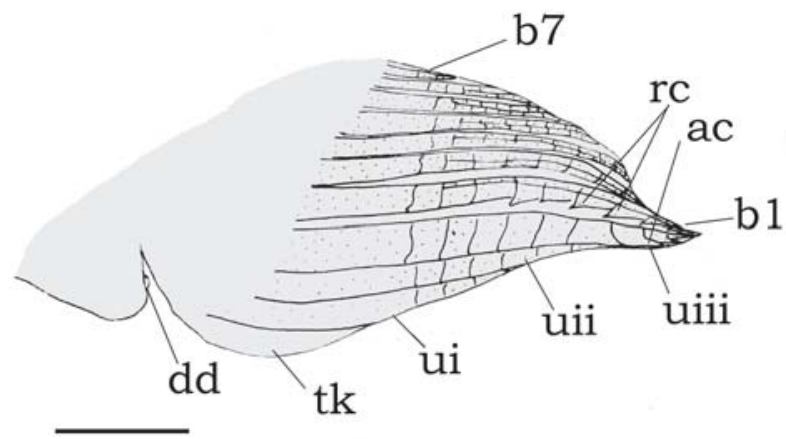

Fig. 15. Male modified anal fin of Tatia brunnea, RMNH 26196, holotype, $56.5 \mathrm{~mm}$ SL. Left side lateral view. Abbreviations: ac, antrorsely curved denticulation; b1, branched first ray; b7, branched seventh ray; dd, deferent duct; rc, retrorsely curved denticulation; tk, tegumentary keel; ui, unbranched first ray; uii, unbranched second ray; uiii, unbranched third ray. Scale bar $=1.0 \mathrm{~mm}$. 
Paratypes. Brazil, Pará: MPEG 6201 (7, 1 CS, 29.3-40.7 mm SL); MNRJ 28821 (2, 31.3-35.3 mm SL), all collected with the holotype.

Diagnosis. Tatia caxiuanensis is distinguished from its congeners by a distinctive male modified anal fin, with elongate rays, with no denticulations on ray segments. The new species is also distinguished by the following combination of characters, as cranial fontanel wide, with a single opening; infraorbital 1 with pronounced ventral process, almost reaching the antero-ventral border of eye rim; nasal ossified as tubes, with no medial flanges of bone and not sutured to mesethmoid; five branched pectoral-fin rays; and snout deep, depth more than 46.7\% HL. Additional features useful for distinguishing $T$. caxiuanensis include caudal fin lobes with about the same length in both adult females and males; postWeberian vertebrae 32 ; and a smaller adult size, less than 50.0 mmSL.

Description. Measured specimens 29.3-40.7 mm SL; morphometric data presented in Table 5. Body slim, head slightly depressed dorso-ventrally. Head robust, outline of head in dorsal view almost rectangular, broader than long. Dorsal outline of trunk from dorsal-fin base to caudal peduncle gradually compressed laterally. Lateral profile of head from snout tip to above opercular margin slightly convex until pectoralfin insertion. Ventral profile of head and abdomen flat. Ventral profile of body gently curved behind anal fin.

Head integument thick, cranial roof difficult to visualize; well-developed adipose eye lid; eye latero-dorsally located in anterior portion of head; mouth terminal, upper lip extended postero-laterally as well-developed fleshy rictal fold; snout margin rounded; anterior nostril tubular, located on anterior border of snout, above lip; posterior nostril thin, rounded, limited by small skin flap; transverse distance between anterior nostrils proportionally the same as distance between posterior ones. Maxillary barbel of moderate size, extending beyond posterior tip of postcleithral process, reaching vertical through origin or middle of dorsal fin; four mental barbels, tips not reaching pectoral-fin base, arranged in arc along ventral surface of jaw; inner mental barbel about 70.0-78.0\% length of outer mentals. Postcleithral process well developed, almost reaching vertical through origin of dorsal fin. Caudal peduncle moderately deep, its depth about 11.0-13.0\% SL.

Rostral border of cranium broad with mesethmoid broader than longer, premaxilla underneath with synchondral articulation; cranial fontanel elliptical, with single large opening, bounded by mesethmoid and frontal; nasal ossified, tubular, with no medial flanges (Fig. 17). Autopalatine tubular, oriented obliquely to longitudinal axis of body; maxilla about same size of autopalatine; prevomer expanded with a well developed arrow-shaped lateral processes; jaws of equal size; premaxilla and dentary with three rows of conical teeth. First nuchal plate short, pentagonal; second nuchal plate laterally concave; third nuchal plate projected laterally, with pronounced narrow tip. Epioccipital process small.
Suspensorium, hyoid arch, branchial skeleton and opercular bones as in generic description. Suprapreopercle present as long canal bone. Six branchiostegal rays articulated with hyoid arch: four with anterior ceratohyal and two with posterior ceratohyal. Basibranchial 2 forming osseous rod with broad cartilaginous anterior tip, separated from shorter basibranchial 3 .

Four infraorbital bones in incomplete series. Infraorbital 1 thin, with short ventro-lateral process around anterior border of eye; remaining infraorbitals thin, reduced to canalicular portions. Infraorbital 2 smallest, close to infraorbital 1, followed by non-ossified portion of canal below eye and by two posterior canal bones much close to sphenotic, forming rear of orbit. Lateral line on body with ossified canal bones only near head.

Dorsal fin I,5; dorsal-fin spine with 15-17 antrorse serrations along entire anterior margin, posterior margin smooth. Pectoral fin I,5; pectoral-fin spine with 17-20 antrorse serrations along anterior margin; 14-15 retrorse serrations along posterior margin; serrations along both margins progressively larger towards spine tip. Pelvic-fin i,5, margin rounded. Adipose fin large, origin on vertical through middle anal-fin base.

Table 5. Morphometric data for Tatia caxiuanensis. SD = standard deviation.

\begin{tabular}{|c|c|c|c|c|c|}
\hline & $\begin{array}{c}\text { Holotype } \\
\text { MPEG } 9859\end{array}$ & $\begin{array}{l}\text { Range } \\
(n=10)\end{array}$ & Mean & $\mathrm{SD}$ & $\mathrm{N}$ \\
\hline Standard length & 32.6 & $29.3-40.7$ & 32.8 & & 10 \\
\hline \multicolumn{6}{|c|}{ Percents of standard length } \\
\hline Body depth & 17.8 & $14.7-19.9$ & 17.1 & 1.46 & 10 \\
\hline Body width & 21.5 & $19.8-22.2$ & 20.9 & 0.68 & 10 \\
\hline Caudal peduncle depth & 13.0 & $11.0-13.0$ & 11.9 & 0.71 & 10 \\
\hline Caudal peduncle length & 25.5 & $25.5-30.0$ & 27.7 & 1.97 & 10 \\
\hline Predorsal length & 30.7 & $28.5-33.8$ & 31.0 & 1.52 & 10 \\
\hline Preanal length & 72.4 & $62.1-72.4$ & 65.9 & 3.68 & 10 \\
\hline Prepelvic length & 46.9 & $46.4-51.1$ & 48.3 & 1.36 & 10 \\
\hline Dorsal origin to pectoral origin & 23.0 & $19.0-23.4$ & 21.5 & 1.42 & 10 \\
\hline Dorsal origin to pelvic origin & 29.1 & $25.2-29.9$ & 28.0 & 1.57 & 10 \\
\hline Pectoral origin to pelvic origin & 30.4 & $30.0-35.6$ & 33.0 & 1.92 & 10 \\
\hline Prepectoral length & 19.3 & $17.2-22.7$ & 19.9 & 1.54 & 10 \\
\hline Dorsal-fin base length & 10.1 & $8.6-11.4$ & 10.1 & 0.89 & 10 \\
\hline Adipose-fin base length & 11.7 & $9.3-14.0$ & 12.2 & 1.54 & 10 \\
\hline Anal-fin base length & 4.3 & $4.2-11.9$ & 8.2 & 2.79 & 10 \\
\hline Dorsal-fin spine length & 19.9 & $14.5-19.9$ & 18.0 & 1.65 & 10 \\
\hline Pectoral-fin spine length & 20.2 & $16.9-22.9$ & 21.1 & 1.69 & 10 \\
\hline Postcleithral process length & & $16.0-22.4$ & 18.0 & 1.83 & 10 \\
\hline First branched pelvic-fin ray & 13.2 & $12.0-15.9$ & 13.4 & 1.15 & 10 \\
\hline Longest anal fin ray & 10.7 & $7.4-12.3$ & 10.5 & 1.38 & 10 \\
\hline Maxillary barbel length & 34.4 & $30.0-35.5$ & 33.4 & 1.97 & 10 \\
\hline Outer mental barbel length & & $7.3-10.6$ & 8.9 & 0.86 & 10 \\
\hline Mental barbel length & 6.4 & $4.7-7.6$ & 6.3 & 0.78 & 10 \\
\hline Head length & 24.2 & $19.9-27.0$ & 23.7 & 1.98 & 10 \\
\hline \multicolumn{6}{|c|}{ Percents of head length } \\
\hline $\mathrm{Hea}$ & 77.2 & $74.0-79.2$ & 76.8 & 1.89 & 10 \\
\hline Snout depth & 48.1 & $46.8-50.7$ & 48.7 & 1.75 & 10 \\
\hline Interorbital distance & 57.0 & $54.4-59.2$ & 56.8 & 1.89 & 10 \\
\hline Left internarial width & 24.1 & $21.5-27.6$ & 23.4 & 1.74 & 10 \\
\hline Anterior internarial distance & 40.5 & $38.9-44.1$ & 41.5 & 1.51 & 10 \\
\hline Posterior internarial distance & 41.8 & $38.3-43.4$ & 40.4 & 1.52 & 10 \\
\hline Snout length & 39.2 & $34.7-39.5$ & 37.2 & 1.95 & 10 \\
\hline Orbital diameter & 29.1 & $26.5-31.6$ & 28.5 & 1.74 & 10 \\
\hline Mouth width & 50.6 & $46.5-52.0$ & 49.3 & 1.91 & 10 \\
\hline
\end{tabular}




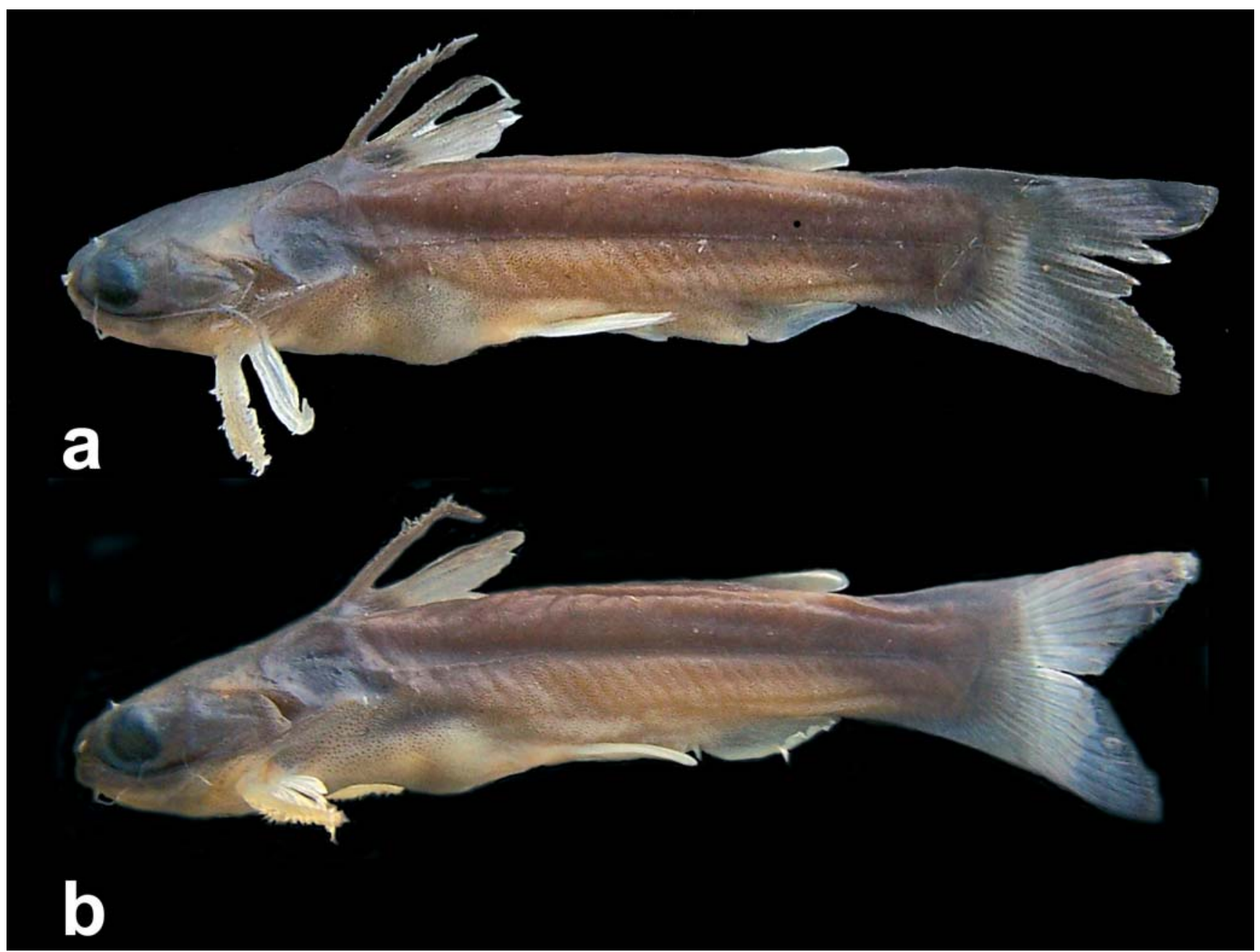

Fig. 16. Tatia caxiuanensis. (a) holotype, MPEG 9859, male, $32.6 \mathrm{~mm}$ SL. (b) paratype, MPEG 6201, female, $40.7 \mathrm{~mm}$ SL, Caxiuanã, Pará State, Brazil.

Anal fin iii, 7; anal-fin pterygiophores in 8 rod-like proximal radials and seven cartilaginous distal radials. Caudal fin forked, lobes with rounded tips, $8+9$ principal rays, 5- 8 upper procurrent, 5-6 lower procurrent rays. Caudal fin lobes about same length in both adult females and males. Nine pleural ribs attached to consecutive vertebrae. Post-Weberian vertebrae $32(n=1)$.

Color in alcohol. Dorsal mid-line and latero-dorsal parts of body dark brown, with many small dark chromatophores, less concentrated over lips and chin. Head and nuchal shield dark. Ventrolateral parts of body pale, belly whitish. Dorsal-fin spine dark pigmented, subsequent rays grayish with dark base. Pectoral, pelvic, anal and adipose fins hyaline. Caudal fin dark brown, with dark chromatophores on fin rays.

Sexual dimorphism. Based on observation of gonads, all examined T. caxiuanensis are adults. In females a genital papilla is not evident. The genital papilla of mature males is visible, with a skin tube around deferent duct. The anal fin of mature male is strongly modified with the second and third unbranched plus first branched rays elongated and thickened, ending in a rounded curved tip (Fig. 18, uiii, b1). No tegumentary keel precedes the first unbranched anal-fin ray. The second unbranched ray is elongated, with an intermediate size between the neighboring first and third rays. The third unbranched and first branched rays are the longest (Fig. 18, uiii, b1). The distal most segments of the third unbranched ray are antrorsely curved (Fig. 18, ac). The second branched ray has a narrow tip. Posterior branched rays are progressively shorter and not reduced.

Distribution. Known only from the type locality in Curuá river, lower Amazon basin, about $330 \mathrm{~km}$ southwest from the city of Belém, Pará, Brazil (Fig. 6).

Etymology. The specific name, caxiuanensis, is in reference to the Floresta Nacional de Caxiuanã, a preservation area where the catfishes were caught.

Remarks. Tatia caxiuanensis is one of the smallest Tatia, reaching maturity at $29.3 \mathrm{~mm}$ SL. Only $T$. gyrina reaches maturity at a smaller size $(28 \mathrm{~mm} \mathrm{SL})$. 


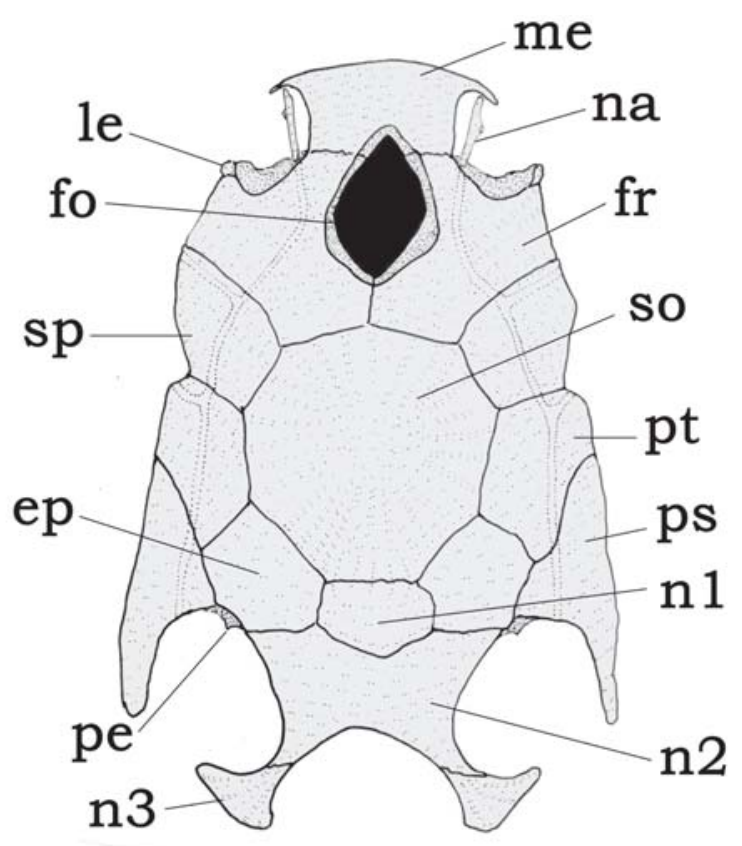

Fig. 17. Neurocranium of Tatia caxiuanensis, new species, MPEG 6201, 29.3 mm SL. Dorsal view. Abbreviations: ep, epioccipital; fo, single cranial fontanel, fr, frontal; le, lateral ethmoid; me, mesethmoid; na, nasal; n1, first nuchal plate, n2; second nuchal plate; n3, third nuchal plate; pe, posterior epioccipital process; ps, posttemporal-supracleithrum; pt, pterotic; so, supraoccipital; sp, sphenotic. Scale bar $=1 \mathrm{~mm}$.

\section{Tatia dunni (Fowler, 1945)}

Figs. 19-21

Centromochlus intermedius. Steindachner, 1882: 4 [Jutaí and Jatuarana]. Eigenmann \& Eigenmann, 1888: 156 [Tajapuru, Tefé, Jatuarana, Icá, Jutaí, Lago Aleixo]. Eigenmann \& Eigenmann, 1890: 269 [Amazonas, Solimões and tributaries].

Centromochlus aulopygius. Eigenmann \& Eigenmann, 1891: 34 [in part, Amazonas, Solimões and tributaries]. Miranda Ribeiro, 1968:10, fig. IX [Amazonas].

Tatia intermedia. Miranda Ribeiro, 1911: 360 [in part, Jutaí, Jutuarana, Tajapuru, Teffé, Içá, Lago Aleixo]. Gosline, 1945: 10 [Amazonas, Solimões and Tributaries]. Sands, 1984: 37 [reference]. Ortega \& Vari, 1986:14 [reference]. Burgess, 1989: 242, pl. 113 [Amazon]. Soares-Porto, 1998: 333 [citation].

Centromochlus dunni Fowler, 1945b: 111, figs. 11-13 [type locality: Colombia, Morelia, Caquetá river drainage]. Fowler, 1951: 462 [upper Amazon, Colombia]. Rössel, 1962: 20 [no locality]. Lüling, 1963: 50, fig. 15 [Quisto Cocha, Iquitos]. Böhlke, 1984:24 [reference].

Tatia aulopygia. Miranda Ribeiro, 1962: 10 [Amazonas].

Tatia dunni. Ferraris, 2003:476 [checklist]. Ferraris, 2007: 77 [checklist].

Diagnosis. Tatia dunni is distinguished by a unique combination of characteristics: nasal ossified with narrow medial flanges partially sutured to lateral margin of mesethmoid; anal-

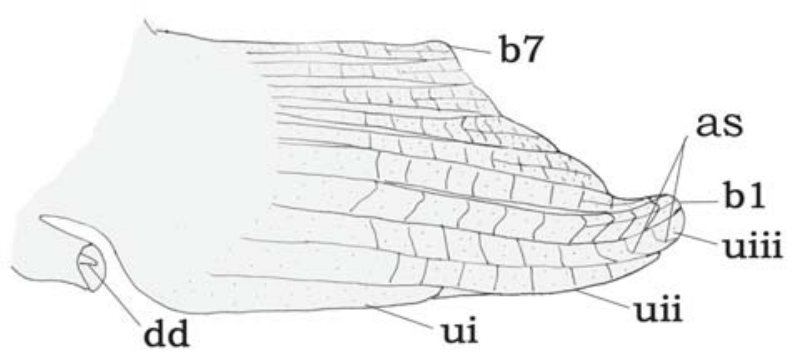

Fig. 18. Male modified anal fin of Tatia caxiuanensis, new species, MPEG 6201, 29.3 mm SL. Left side lateral view. Abbreviations: as, antrorsely curved segment; b1, branched first ray; b7, branched seventh ray; dd, deferent duct; ui, unbranched first ray; uii, unbranched second ray; uiii, unbranched third ray. Scale bar $=1.0 \mathrm{~mm}$.

fin rays iii, 6-7; modified anal fin in mature males with short tip; first unbranched anal-fin ray with segments fused; last branched ray normally developed, not reduced (Fig. 21); ribs 10 ; and vertebrae 35 . Additional features useful for distinguishing T. dunni include details in coloration, as: contour of mouth dark, same color as head; posterior border of nuchal shield usually dark; pectoral-fin spine usually dark brown; body coloration with irregular blotches or stripes, large specimens with faint stripes or blotches; and caudal fin dark with whitish blotches.

Description. Measured adult specimens 66.1-114.5 mm SL; morphometric data presented in Table 6. Body deep, head depressed dorso-ventrally. Head robust, outline of head in dorsal view somewhat elliptic, slightly broader than long. Trunk from dorsal-fin base to caudal peduncle becoming gradually compressed laterally. Outline of head in dorsal view from snout tip to opercular margin slightly convex until pectoral-fin insertion. Ventral profile of head and abdomen slightly convex. Ventral profile of body compressed behind anal-fin origin. Head integument thin, cranial roof visible; well-developed adipose eye lid; eye latero-dorsally located in anterior portion of head; mouth terminal, upper lip extended posterolaterally as well-developed fleshy rictal fold; anterior nostril tubular, located on anterior border of snout; posterior nostril large, rounded, limited by small skin flap; transverse distance between anterior nostrils proportionally the same as distance between posterior ones in HL. Maxillary barbel short, extending close to posterior margin of postcleithral process; mental barbel short, tips not reaching pectoral-fin base; inner mental barbel about $60.0-90.0 \%$ length of outer mentals. Postcleithral process almost reaching vertical through middle or end of dorsal fin. Caudal peduncle deep, depth about 14.1-18.6\% SL.

Rostral border of cranium broad with mesethmoid broader than long; premaxilla underneath with synchondral articulation; cranial fontanel elliptical, bounded by mesethmoid and frontal (Fig. 20); nasal ossified with narrow medial flanges partially sutured to lateral margin of mesethmoid; autopalatine tubular, oriented obliquely to longitudinal axis of body; max- 


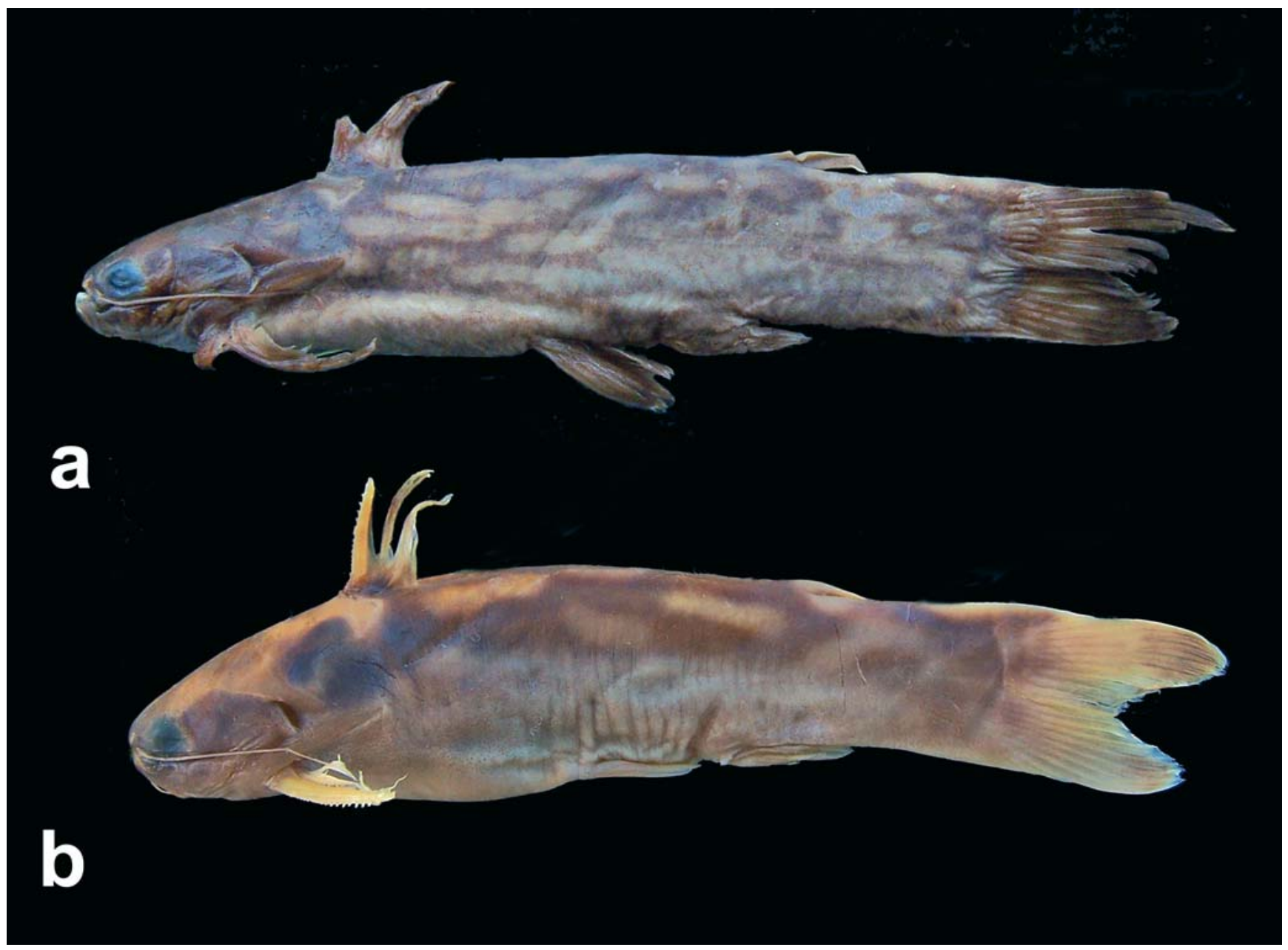

Fig. 19. Tatia dunni. (a) ANSP 71705, holotype, male, $83.3 \mathrm{~mm}$ SL, Caquetá river drainage, Colombia. (b) FMNH 88187, female, $77.5 \mathrm{~mm}$ SL, Conambo river, Ecuador.

illa about same size of autopalatine; prevomer expanded anteriorly with well developed arrow-shaped lateral processes; jaws of equal size; premaxilla and dentary with three to four rows of conical teeth. First nuchal plate trapezoid; second nuchal plate slightly concave along lateral margins; third nuchal plate curved, projected laterally, with broad tip. Epioccipital process very small.

Suspensorium, hyoid arch, branchial skeleton and opercular bones as in generic description. Suprapreopercle present as short canal bone. Six branchiostegal rays articulated with hyoid arch: four with anterior ceratohyal and two with posterior ceratohyal; last two flattened and expanded.

Five infraorbital bones in incomplete series. Infraorbital 1 flattened with short ventro-lateral process; remaining infraorbitals thin, reduced to canalicular portions. Infraorbitals 2 and 3 close to infraorbital 1, followed by non-ossified portion of canal below eye and by two posterior short canal bones, forming posterior orbital rim. Lateral line on body with ossified canal bones posteriorly to vertical through pelvic fin origin.

Dorsal fin I,4-5, rarely I,4 ( $\mathrm{n}=13)$; dorsal-fin spine with 1315 antrorse serrations along entire anterior margin; posterior margin smooth. Pectoral fin I,5 ( $\mathrm{n}=13)$; pectoral-fin spine with
17-19 antrorse serrations along anterior margin; 11-13 retrorse serrations along posterior margin; serrations along both margins progressively larger towards spine tip. Pelvic-fin i,5 $(n=13)$, margin rounded. Adipose fin small, origin on vertical through end of anal-fin base. Anal fin iii, 6-7 ( $\mathrm{n}=13)$; anal-fin pterygiophores in 8 rod-like proximal radials and seven cartilaginous distal radials. Caudal fin forked, lobes with rounded tips, 8+9 principal rays, 11-18 upper procurrent, 11-20 lower procurrent rays $(\mathrm{n}=13)$. Pleural ribs 10 , attached to consecutive vertebrae. Post-Weberian vertebrae $35(n=5)$.

Color in alcohol. Coloration in preserved specimens umber, with rather long longitudinal pale grayish to whitish irregular blotches; dark markings form reticulations; under surface of head and abdomen whitish; fins with darker markings, more contrasted on caudal (Fowler, 1945b: 111). Dorsal surface of head almost dark brown; posterior part of nuchal shield faint, usually light brown. Contour of lips and anterior nostrils usually dark. Ventral part of head dark brown around chin barbels. Caudal fin dark with whitish spots over lobes.

Color variation. Tatia dunni usually has faint irregular bands 
and spots over body. Some T. dunni, from the Peruvian Amazon, have a dark brown body and mottled anal fin (INHS 43890). Large specimens from the Purus river, in central Amazonia, usually have a completely dark body (INPA 17182) or a lightly spotted coloration (INPA 17184).

Sexual dimorphism. Based on examination of gonads, T. dunni attains sexual maturity above $70 \mathrm{~mm}$ SL. In mature females a genital papilla is not evident. The genital papilla of mature male is visible, with an emergent deferent duct. The anal fin of mature male (Fig. 21) is strongly modified, with three thickened unbranched rays. The first unbranched anal-fin ray has segments fused and is immediately preceded by a short tegumentary keel (Fig. 21, tk). The second unbranched ray has an intermediate size between the neighboring first and third rays. Third unbranched is the longest ray forming a short rounded tip (Fig. 21, uiii); distal segments smaller, antrorsely curved (Fig. 21, ac). First branched ray bearing retrorsely curved distal segments (Fig. 21, rc). Posterior branched rays are progressively shorter, with the last branched one somewhat reduced (Fig. 21, b6).

Hemal spines 15-18 interdigitate with anal-fin pterygiophores; with hemal spines 15-17 thickened in mature male, but are undifferentiated in females. The caudal-fin lobes

Table 6. Morphometric data for Tatia dunni. $\mathrm{SD}=$ standard deviation.

\begin{tabular}{|c|c|c|c|c|}
\hline & Range & Mean & SD & $\mathrm{N}$ \\
\hline Standard length & $66.1-114.5$ & 82.5 & & 15 \\
\hline \multicolumn{5}{|c|}{ Percents of standard length } \\
\hline Body depth & $15.7-26.3$ & 19.4 & 2.49 & 15 \\
\hline Body width & $17.8-24.7$ & 21.5 & 1.57 & 15 \\
\hline Caudal peduncle depth & $14.1-18.6$ & 15.2 & 1.49 & 15 \\
\hline Caudal peduncle length & $23.0-28.2$ & 24.7 & 1.87 & 15 \\
\hline Predorsal length & $29.2-36.7$ & 31.9 & 1.79 & 15 \\
\hline Preanal length & $70.0-75.0$ & 72.0 & 1.98 & 15 \\
\hline Prepelvic length & $49.2-56.1$ & 51.7 & 1.96 & 15 \\
\hline Dorsal origin to pectoral origin & $20.2-28.2$ & 23.6 & 1.81 & 15 \\
\hline Dorsal origin to pelvic origin & $27.0-33.3$ & 29.9 & 2.38 & 15 \\
\hline Pectoral origin to pelvic origin & $30.7-38.9$ & 34.7 & 2.02 & 15 \\
\hline Prepectoral length & $17.5-22.9$ & 20.5 & 1.56 & 15 \\
\hline Dorsal-fin base length & $7.8-12.4$ & 10.0 & 1.41 & 15 \\
\hline Adipose-fin base length & $6.1-12.6$ & 9.8 & 1.83 & 15 \\
\hline Anal-fin base length & $5.4-9.6$ & 7.7 & 1.99 & 15 \\
\hline Dorsal-fin spine length & $13.8-19.7$ & 17.0 & 2.25 & 13 \\
\hline Pectoral-fin spine length & $19.7-25.3$ & 22.3 & 1.60 & 13 \\
\hline Postcleithral process lenght & $15.6-21.6$ & 16.9 & 2.27 & 15 \\
\hline First branched pelvic-fin ray & $11.7-16.2$ & 13.6 & 1.37 & 15 \\
\hline Longest anal fin ray & $5.2-14.1$ & 8.9 & 2.15 & 15 \\
\hline Maxillary barbel length & $27.3-32.9$ & 30.1 & 2.17 & 15 \\
\hline Outer mental barbel length & $6.6-14.2$ & 9.5 & 1.93 & 15 \\
\hline Mental barbel length & $3.1-8.0$ & 5.6 & 1.07 & 15 \\
\hline Head length & $21.1-29.5$ & 24.1 & 2.28 & 15 \\
\hline \multicolumn{5}{|c|}{ Percents of head length } \\
\hline Head width & $76.0-80.1$ & 78.5 & 1.82 & 15 \\
\hline Snout depth & $47.0-51.7$ & 48.7 & 1.81 & 15 \\
\hline Interorbital distance & $54.1-59.4$ & 58.2 & 1.83 & 15 \\
\hline Left internarial width & $18.3-25.5$ & 22.1 & 2.10 & 15 \\
\hline Anterior internarial distance & $38.3-44.8$ & 41.7 & 2.16 & 15 \\
\hline Posterior internarial distance & $36.1-42.0$ & 38.6 & 1.75 & 15 \\
\hline Snout length & $36.1-42.2$ & 39.0 & 2.20 & 15 \\
\hline Orbital diameter & $20.0-26.4$ & 26.4 & 2.60 & 15 \\
\hline Mouth width & $48.1-52.3$ & 51.0 & 1.75 & 15 \\
\hline
\end{tabular}

have the same length in mature female, whereas upper lobe is slightly elongated in mature male.

Distribution. Tatia dunni has a wide distributional range, occurring in the upper Amazon, Ecuador and Colombia and the central Amazon, Brazil, in Solimões and Purus rivers. It is the species of Tatia that occurs at the highest elevations as it has been recorded at $1950 \mathrm{~m}$ abs, in Caquetá river drainage, Cauca mountains Morelia, Colombia (Fig. 6).

Remarks. Tatia dunni was placed in the synonymy $T$. intermedia by Mees (1974). The shared presence of white markings on dark body in both species was considered within the limits of intraspecific variation (Mees, 1974: 68). In spite of similarities in coloration, T. dunni is distinguished by its long preanal length, $70.0-75.0 \% \mathrm{SL}$ ( $v s .65 .0-69.4 \% \mathrm{SL}$ in $T$. intermedia) and short interorbital distance, 54.1-59.4\% HL (vs. 60.1-63.6\% HL in T. intermedia). The male modified anal fin differs in both species. In T. dunni the last branched ray is markedly reduced ( $v s$. only slightly shorter than penultimate ray in T. intermedia).

Material examined. 48 specimens (28.4-114.9 mm SL). Holotype. Colombia: ANSP 71705, 1 (83.3 mm SL), upper Amazonas, Morelia, Caquetá river drainage (holotype of Centromochlus dunni). Paratype. Colombia: ANSP 71706, 1 (50.1 mm SL), Alto Amazonas,

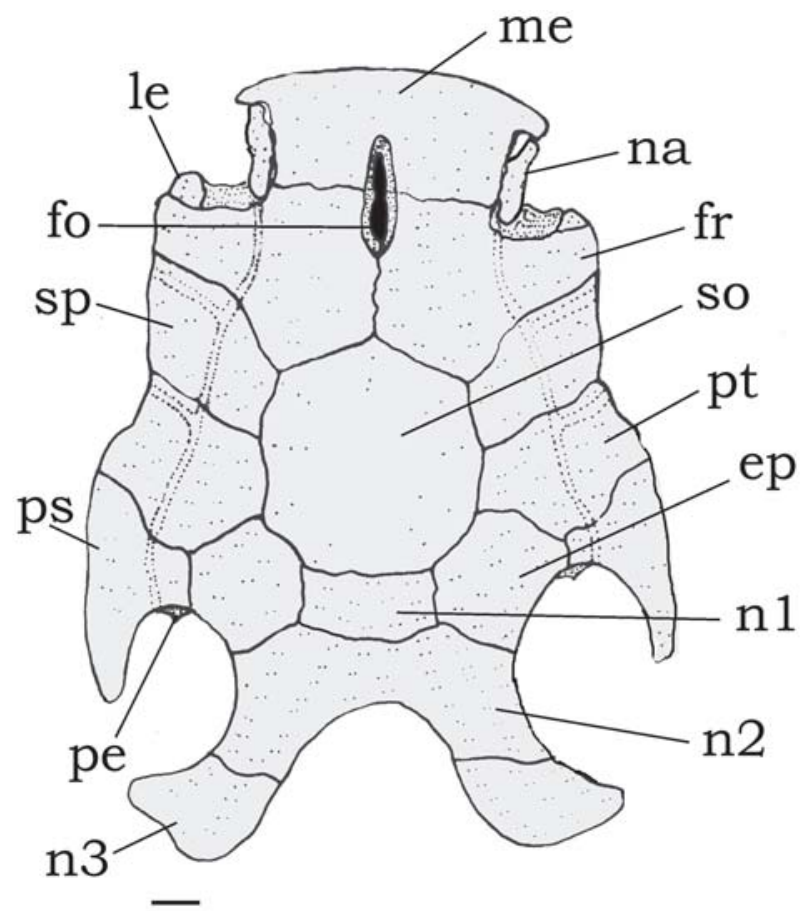

Fig. 20. Neurocranium of Tatia dunni, ANSP 71706, paratype, $50.1 \mathrm{~mm}$ SL. Dorsal view. Abbreviations: ep, epioccipital; fo, single cranial fontanel, fr, frontal; le, lateral ethmoid; me, mesethmoid; na, nasal; $\mathbf{n 1}$, first nuchal plate, $\mathbf{n} 2$; second nuchal plate; $\mathbf{n} 3$, third nuchal plate; pe, posterior epioccipital process; ps, posttemporal-supracleithrum; pt, pterotic; so, supraoccipital; sp, sphenotic. Scale bar $=1 \mathrm{~mm}$. 
Morelia, Caquetá river drainage (paratype of Centromochlus dunni). Non-type specimens. Brazil: Amazonas: CAS 52124, 3 (28.4-40.8 $\mathrm{mm} \mathrm{SL}$ ), Castelo Branco, lago Grande, Amazonas river; CAS 60681, 3 (81.0-97.2 mm SL), Amazon basin; INPA 3017, 1 (69.0 mm SL), Catalão, Solimões river, igarapé Madalena; INPA 18477, 3 (72.0$87.8 \mathrm{~mm} \mathrm{SL})$, Tupinambaranas Island; INPA 17182, $1(91.7 \mathrm{~mm}$ SL), Purus river; INPA 17184, 2 (98.8-103.0 mm SL), Jari Lake, Purus river; MZUSP 44127, 1 (93.3 mm SL), Pauini. Ecuador: AMNH 58405, 3 (50.3-94.7 mm SL). AMNH 58406, 2 (66.7-70.8 mm SL), western Ecuador; FMNH 88187, 3 (66.1-84.2 mm SL), Conambo river, mouth of Shiona river, eastern Ecuador; FMNH 92007, 1 plus 1CS, (96.9 mm SL), Conambo river, mouth of Shiona river, eastern Ecuador; FMNH 92008, 1 (114.9 mm SL), Corrientes river, Napo, eastern Ecuador; FMNH 103964, 5, Zancudococha lake, Aguarico river drainage; FMNH 103965, 2, Blanco river close to Tiputini river upstream from bridge; FMNH 103966, 1, laguna Grande de Cuyabeno and Quebrada de Hormigas, Aguarico river drainage; FMNH 103967, 1, Cuyabeno river, about 1-3 km upstream of mouth of Aguarico river; FMNH 103968, 2, tributary of lower Cuyabeno river; FMNH 103969, 2, lake communicating with Lagartococha river, about $25 \mathrm{Km}$ upstream from mouth of Aguarico river; FMNH 103970, 1, Aguas Negras river, about 1-2 Km upstream from bridge. Peru: CAS 158882, 1 (90.8 mm SL) (R), Ampiyacu river, near Pebas, Loreto department; CAS 158883, 1 (69.1 mm SL) (R), Chancho rivulet, near Pebas, Loreto department; CAS 158884, 1 (49.2 mm SL) (R), Yaguas Yacu, near Pebas, Loreto department; INHS 43890, 2 (48.9-77.3 mm SL), Quebrada Shushuma, Nanay river drainage, Amazon basin; USNM 124901, 1 (60.0 mm SL) (R), Shansho creek, Ampiyacu river drainage.

\section{Tatia galaxias Mees, 1974}

Figs. 22-24

Centromochlus aulopygius. Pellegrin, 1899: 188 [Apuré, Venezuela]. Schultz, 1944: 240 [Venezuela]. Puyo, 1949: 97 [streams on region of Approuage].

Tatia aulopygia. Gosline, 1945: 10 [in part, Apuré]. MagoLeccia, 1967: 225 [Venezuela]. Burgess, 1989: 242, pl. 113, 114 [northeastern South America].

Tatia galaxias Mees, 1974: 86-88, fig. 23. [type locality: Quiribana rivulet, Orinoco Basin, Venezuela]. Sands, 1984:

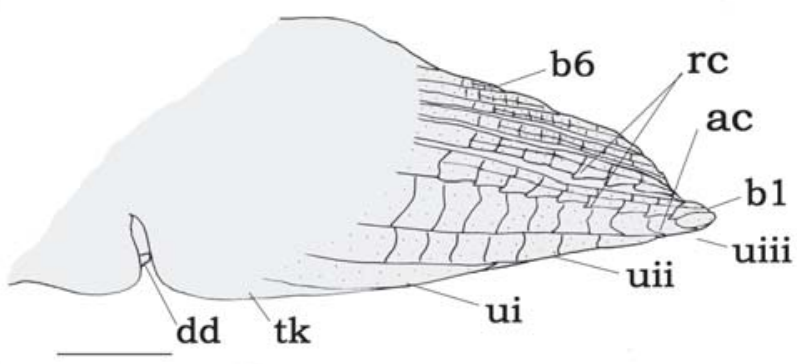

Fig. 21. Male modified anal fin of Tatia dunni, holotype, ANSP 71705, 83.3 mm SL. Left side lateral view. Abbreviations: ac, antrorsely curved denticulation; b1, branched first ray; b6, branched sixth ray; dd, deferent duct; rc, retrorsely curved denticulation; tk, tegumentary keel; ui, unbranched first ray; uii, unbranched second ray; uiii, unbranched third ray. Scale bar $=1 \mathrm{~mm}$.
36-37 [Venezuela]; Mees, 1988: 411-412 [Guarapiche river, Venezuela]; Burgess, 1989: 242 [Apure, Venezuela]; Franke, 1990: 20-34 [notes on reproduction]. Soares-Porto, 1998: 331-350 [citation]. Ferraris, 2003: 476 [checklist]. Lasso et al., 2004: 139 [Cataniapo, Bita, Meta, Suapure, Apure, Caura, Morichal Largo, Delta, Orinoco]. Ferraris, 2007: 77 [checklist].

Tatia intermedia. Soares-Porto, 1998: 333 [citation]. Ferraris, 2003:477 [checklist]. Lasso et al., 2004: 139 [Bita, Apure, Caroní, Orinoco].

Diagnosis. Tatia galaxias is uniquely distinguished from congeners by its well developed postcleithral process, reaching almost to a vertical through the dorsal-fin origin; a large eye, 37.0-42.9\% HL (vs. 17.4-31.6\% in other Tatia); and by a short snout $23.1-28.9 \%$ HL (vs. 31.2-43.6\% in other Tatia). The species is also distinguished by the following combination of characteristics: narrow elliptical cranial fontanel; ribs 7 (vs. 8-11 in most other Tatia, except T. strigata with 7 ribs and T. gyrina with 5-6 ribs). Additional features useful for distinguishing $T$. galaxias include: nasal ossified with wide medial flanges partially sutured to lateral margin of mesethmoid; coloration variable, sides of body usually dark with light, rounded spots or dots, or sometimes uniformly pale brown; toothed prevomer in examined large adult specimens.

Description. Measured adult specimens 54.2-125.6 mm SL; morphometric data presented in Table 7. Body slim, head slightly depressed dorso-ventrally. Head large, robust, outline of head in dorsal view elliptic, broader than long. Dorsal outline of trunk from dorsal-fin base to caudal peduncle gradually compressed posteriorly. Lateral profile of head from snout tip to above opercular margin slightly convex to pectoral-fin insertion. Ventral profile of head and abdomen flat. Ventral profile of body concave posterior to anal fin.

Head integument thin, cranial roof visible; well-developed adipose eye lid; eye latero-dorsally located in anterior portion of head; mouth terminal, upper lip extended posterolaterally as well-developed fleshy rictal fold; snout margin rounded; anterior nostril tubular, located on anterior border of snout; posterior nostril large, rounded, limited by small skin flap; transverse distance between anterior nostrils larger than distance between posterior ones. Maxillary barbel reaching vertical through end of dorsal-fin; mental barbel short, tips not reaching pectoral-fin base, arranged in arc along ventral surface of jaw; inner mental barbel about 50.0-67.0\% length of outer mentals. Postcleithral process short, reaching vertical through origin of dorsal fin. Caudal peduncle deep, its depth about 14.2-18.3\% SL.

Rostral border of cranium with mesethmoid as long as broad; premaxilla underneath with synchondral articulation; cranial fontanel elliptical, bounded by mesethmoid and frontal (Fig. 23); nasal ossified, with medial flanges sutured to lateral margin of mesethmoid; autopalatine tubular, oriented obliquely to longitudinal axis of body; maxilla small, shorter 
than autopalatine. Prevomer expanded anteriorly, with well developed arrow-shaped lateral processes, bearing small teeth attached to process in a large specimen with $85 \mathrm{~mm} \mathrm{SL} \mathrm{(MCNG}$ 25983). Jaws of equal size; premaxilla and dentary with two to three rows of conical teeth. First nuchal plate pentagonal; second nuchal plate broad, laterally concave; third nuchal plate projected laterally, with curved distal tip. Epioccipital process very small.

Suspensorium, hyoid arch, branchial skeleton and opercular bones as in generic description. Suprapreopercle large. Six branchiostegal rays articulated with hyoid arch: four with anterior ceratohyal and two with posterior ceratohyal; last one largest and expanded.

Seven to eight infraorbital bones in usually complete series. Rarely incompletely ossified with 5 canal bones. Infraorbital 1 thin, with short ventro-lateral process limited to anterior border of eye; remaining infraorbitals thin, reduced to canalicular portions. Infraorbital 2-4 small, close to infraorbital 1. Infraorbitals 5-6 long ossified canals, bordering eye below and posteriorly. Last infraorbital much small, forming posterior orbital rim, in contact to sphenotic. Lateral line on body with ossified canal bones posteriorly to vertical through pelvic origin.

Dorsal fin I,5 $(n=42)$, dorsal-fin spine with 15-18 antrorse serrations along entire anterior margin; posterior margin smooth.
Pectoral fin I,5 ( $\mathrm{n}=42)$, pectoral-fin spine with 19-25 antrorse serrations along anterior margin; 13-17 retrorse serrations along posterior margin; serrations along both margins progressively larger towards spine tip. Pelvic-fin i,5 $(n=42)$, margin rounded. Adipose fin moderate in size, origin on vertical through analfin base origin. Anal fin iii, 6-7 ( $n=42)$; anal-fin pterygiophores in eight rod-like proximal radials and seven cartilaginous distal radials. Caudal fin forked, lobes with rounded tips, $8+9$ principal rays, 18-20 upper procurrent, 18-20 lower procurrent rays $(n=42)$. Seven pleural ribs attached to consecutive vertebrae. Post-Weberian vertebrae 32-33 $(n=4)$, rarely 30 .

Color in alcohol. Body usually dark brown with evenly spaced small white dots; chin with scattered pigment; underparts from chin to anus and ventrals unpigmented; pectoral fin pigmented lightly (Mees, 1974: 86). Dorsal fin with dark base and irregular spots; caudal fin usually with whitish spots irregularly distributed over lobes (Fig. 22).

Color variation. Although the body usually is dark brown with whitish spots, $T$. galaxias may be polymorphic for color pattern, as a large array of variation regarding color is observed. Some specimens have a light brown body. Some have small roundish spots over the body and caudal fin, a common pattern in very young specimens $<40 \mathrm{~mm}$ SL. Some have

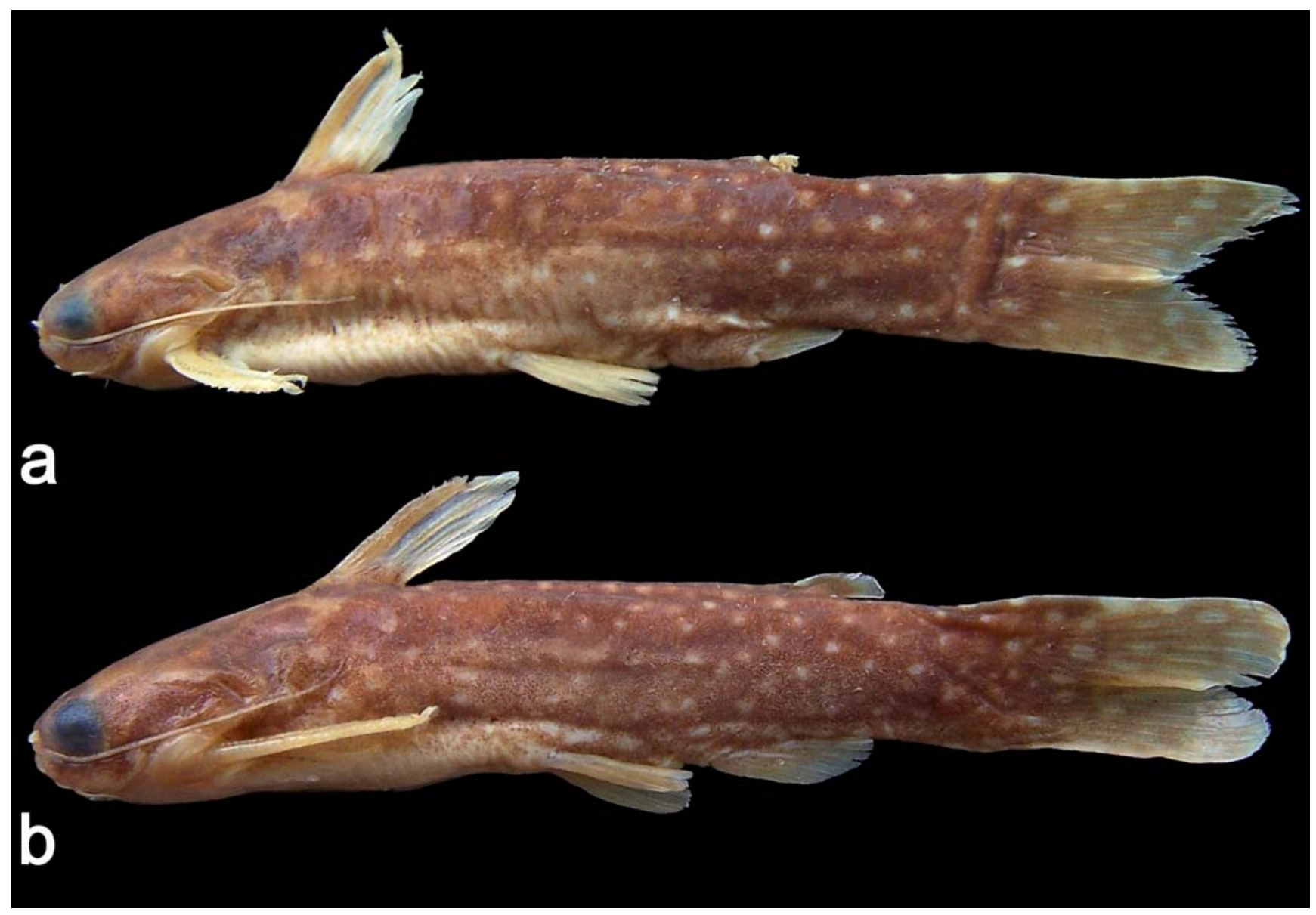

Fig. 22. Tatia galaxias. (a) ANSP 138105, male, 64.6 mm SL. (b) ANSP 138105, female, 54.2 mm SL, El Viento rivulet, Colombia. 
caudal fin with dark tips. All distinct patterns may be found together in the same locality.

Sexual dimorphism. Based on examination of gonads, $T$. galaxias attains sexual maturity above $54.2 \mathrm{~mm}$ SL. In mature females a genital papilla is not evident. A genital papilla is visible in mature male, with a long slender emergent deferent duct (Fig. 24, dd). The male anal fin is strongly modified, with the anterior rays enlarged and thickened. The first unbranched anal-fin ray have segments fused and is preceded by a tegumentary keel (Fig. 24, tk). The second unbranched ray is elongated, with an intermediate size between the neighboring first and third rays. Third unbranched plus the first branched are the longest rays, forming a pointing tip. The third unbranched ray has the distal segments antrorsely curved (Fig. 24, ac). First and second branched rays have retrorsely curved distal segments (Fig. 24, rc). The remaining branched rays are progressively shorter, with the last ray not reduced (Fig. 24, b7).

Hemal spines 15-18 interdigitate with the anal-fin pterygiophores, being the hemal spines 15-17 thickened in mature males, but undifferentiated in females. The caudal-fin lobes have the same length in mature females, whereas in males the upper lobe is slightly elongated.

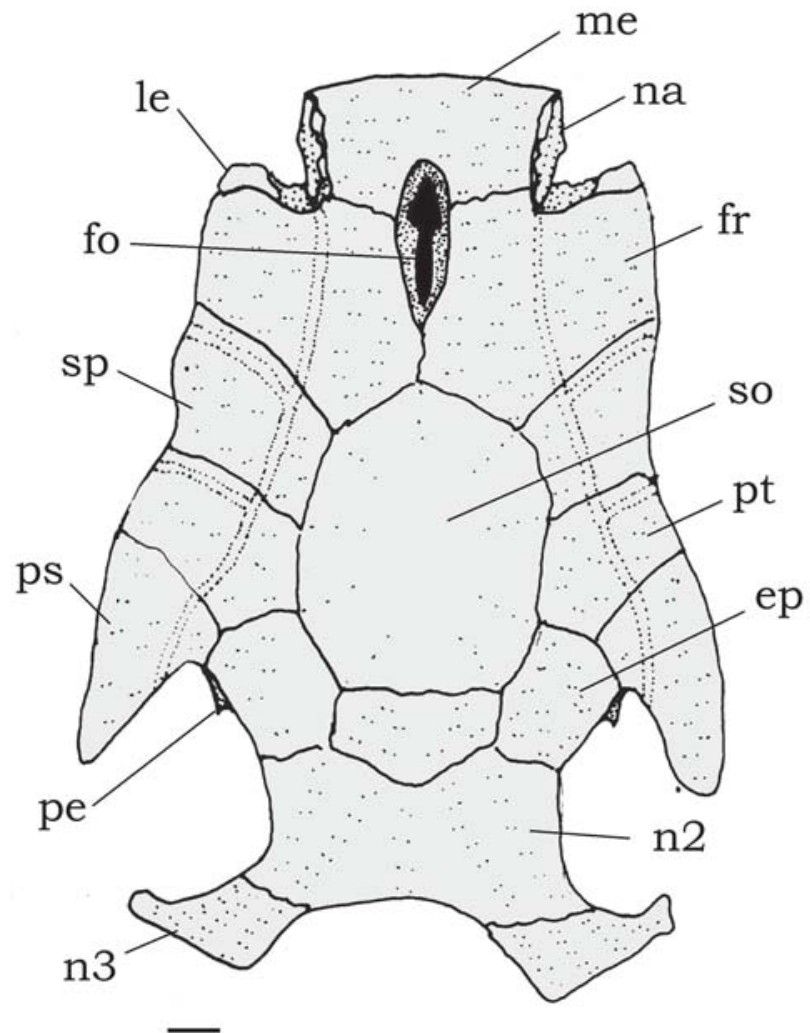

Fig. 23. Neurocranium of Tatia galaxias, RMNH 26493, paratype, $55.6 \mathrm{~mm}$ SL. Dorsal view. Abbreviations: ep, epioccipital; fo, single cranial fontanel, fr, frontal; le, lateral ethmoid; me, mesethmoid; na, nasal; n2, second nuchal plate; $\mathbf{n 3}$, third nuchal plate; pe, posterior epioccipital process; ps, posttemporal-supracleithrum; pt, pterotic; so, supraoccipital; sp, sphenotic. Scale bar $=1.0 \mathrm{~mm}$.
Distribution. Endemic to the Orinoco basin in Venezuela, including Meta drainage, in Colombia (Fig. 6).

Remarks. Mees (1974) described T. galaxias on the basis of its diagnostic color pattern of small white spots evenly spaced over a dark body (pattern exemplified in Fig. 22). Mees, (1974: 88) considered its coloration reminiscent of that of $T$. intermedia, except in T. galaxias the body is darker, the spots smaller, and the tail dark with white spots (vs. pale with dark spots and cross-bars in T. intermedia). We observed the dark body to be geographically variable in both $T$. galaxias and $T$. intermedia. In acidic black water rivers specimens of $T$. galaxias tend to have a darker body, when compared to those from clear water rivers. Together with the pattern of small white spots, other patterns of coloration were recognized among Orinoco specimens, such as uniformly dark and dark with white ellipsoid spots, the latter being rarest. In $T$. galaxias the spots are usually round, whereas in T. intermedia the spots are typically more ellipsoidal. Tatia galaxias also has a larger eye $37.0-42.9 \%$ HL (vs. 21.4-26.3\% in T. intermedia) and fewer ribs, 7, and fewer vertebrae 32-33 (vs. 10 ribs and 35-36 vertebrae in $T$. intermedia).

Tatia galaxias and T. intermedia are the only species of

Table 7. Morphometric data for Tatia galaxias. SD = standard deviation.

\begin{tabular}{|c|c|c|c|c|}
\hline & $\begin{array}{l}\text { Range } \\
(\mathrm{n}=42)\end{array}$ & Mean & $\mathrm{SD}$ & $\mathrm{N}$ \\
\hline Standard length & $54.2-125.6$ & 64.7 & & 15 \\
\hline \multicolumn{5}{|c|}{ Percents of standard length } \\
\hline Body depth & $16.1-22.9$ & 19.2 & 1.98 & 15 \\
\hline Body width & $18.8-24.8$ & 22.3 & 1.35 & 15 \\
\hline Caudal peduncle depth & $14.2-18.3$ & 15.6 & 1.96 & 15 \\
\hline Caudal peduncle length & $21.5-28.0$ & 24.6 & 1.99 & 15 \\
\hline Predorsal length & $28.7-38.1$ & 32.6 & 1.97 & 15 \\
\hline Preanal length & $64.0-69.9$ & 66.3 & 1.95 & 15 \\
\hline Prepelvic length & $45.6-53.2$ & 49.5 & 1.87 & 15 \\
\hline Dorsal origin to pectoral origin & $20.8-28.9$ & 23.9 & 1.98 & 15 \\
\hline Dorsal origin to pelvic origin & $25.0-29.9$ & 27.7 & 1.88 & 15 \\
\hline Pectoral origin to pelvic origin & $29.6-35.8$ & 32.2 & 1.99 & 15 \\
\hline Prepectoral length & $18.8-25.3$ & 21.8 & 1.64 & 15 \\
\hline Dorsal-fin base length & $7.9-12.5$ & 10.4 & 1.17 & 15 \\
\hline Adipose-fin base length & $5.7-14.9$ & 11.8 & 1.98 & 15 \\
\hline Anal-fin base length & $4.6-12.9$ & 9.6 & 1.99 & 15 \\
\hline Dorsal-fin spine length & 15.3-22.1 & 18.6 & 1.96 & 15 \\
\hline Pectoral-fin spine length & $20.0-26.8$ & 23.1 & 1.97 & 15 \\
\hline Postcleithral process length & $16.1-21.3$ & 18.4 & 1.48 & 15 \\
\hline First branched pelvic-fin ray & $11.5-15.3$ & 13.8 & 1.00 & 15 \\
\hline Longest anal fin ray & $6.0-20.1$ & 11.2 & 2.14 & 15 \\
\hline Maxillary barbel length & $22.6-39.8$ & 31.6 & 3.80 & 15 \\
\hline Outer mental barbel length & $5.4-11.0$ & 8.2 & 1.54 & 15 \\
\hline Mental barbel length & $3.7-13.0$ & 5.9 & 1.84 & 15 \\
\hline Head length & $21.7-28.2$ & 24.4 & 1.63 & 15 \\
\hline \multicolumn{5}{|c|}{ Percents of head length } \\
\hline Head width & $78.0-83.6$ & 80.7 & 1.85 & 15 \\
\hline Snout depth & $42.3-48.6$ & 45.5 & 1.92 & 15 \\
\hline Interorbital distance & $54.1-59.9$ & 57.9 & 1.89 & 15 \\
\hline Left internarial width & 18.6-28.6 & 22.0 & 1.86 & 15 \\
\hline Anterior internarial distance & $40.8-48.1$ & 44.2 & 1.87 & 15 \\
\hline Posterior internarial distance & $39.2-45.8$ & 42.1 & 1.96 & 15 \\
\hline Snout length & 23.1-28.9 & 25.3 & 1.95 & 15 \\
\hline Orbital diameter & $37.0-42.9$ & 39.3 & 1.94 & 15 \\
\hline Mouth width & $50.9-55.9$ & 53.2 & 1.87 & 15 \\
\hline
\end{tabular}


the genus bearing a toothed prevomer. Within the Auchenipteridae prevomerian teeth appear in Asterophysus batrachus, in both adults and young specimens. Ferraris (1988) considered the presence of prevomerian teeth in Tatia an aberration. In our examination of $T$. galaxias only a single specimen exhibited teeth. In T. intermedia, however, prevomerian teeth were found in all large specimens $>74 \mathrm{~mm} \mathrm{SL}(\mathrm{n}=4)$. In all other large size (>100 mm SL) centromochlin species, such as Glanidium albescens, G. ribeiroi, G. melanopterum, G. leopardus, Centromochlus schultzi, C. heckelii and $C$. existimatus, the prevomer is edentulous.

Material examined. 57 specimens (27.0-125.6 mm SL). Paratypes. CAS 6568, 4 (49.0-56.6 mm SL) and RMNH 26493, 2 (48.5-55.6 $\mathrm{mm}$ SL) (R), Quiribana rivulet, near Caicara, Orinoco basin (paratypes of Tatia galaxias). Non-type specimens. AMNH 58320, 2 plus $1 \mathrm{CS}$, no locality, probably Venezuela. Colombia: ANSP 138104, 1 (43.4 mm SL); ANSP 138106, 1 (38.0 mm SL), Humacita farm, small stream, probably belonging to the complex of lake Mozambique, Meta river drainage; ANSP 138105, 2 (54.2-64.6 $\mathrm{mm} \mathrm{SL})$, El Viento rivulet, Finca El Viento south of Matazul. Venezuela. Amazonas: AMNH 91381, 1 (125.6 mm SL), Mavaca river; ANSP 160648, 1 (44.0 mm SL), Sipapo river above Pendare; CAS 158873,1 (40.8 mm SL), bifurcation on Orinoco river in Tamatama beach. FMNH 103487, 2 (30.0-36.4 mm SL), Atabapo river close to Sapo island, above San Fernando de Atabapo. MCNG 25983, 1 (85.6 mm SL), Siapa river. MCNG 27966, 1 (39.3 mm SL), Orinoco river in El Tigre island. Apure: FMNH 69928, 2 (27.0-39.6 mm SL), Cinaruco river south of San Fernando de Apure; FMNH 103487 , 2 (31.5-37.5 mm SL), Atabapo river upstream from San Fernando de Atabapo. INHS 60322, 2 (R), Guaritico rivulet, south of Bruzual, Apure river drainage. MCNG 7080, 1 (32.9 mm SL); MCNG 15891, 1 (43.1 mm SL), Maporal Rivulet. Bolivar: ANSP 149691, 1 (39.2 $\mathrm{mm}$ SL), Urbani river on road Maripas-Las Trincheras. ANSP 149973, 17 (28.8-44.4 mm SL), Quiribana rivulet near Caicara, Orinoco basin. ANSP 160571, 2 (34.1-35.5 mm SL), Los Pavones rivulet, tributary of Sipao river, near Farm Fundo Malama. CAS 158860, 2 (28.7-32.0 mm SL); CAS 158865, 3 (43.7-58.4 mm SL); CAS 158879, 1 (54.8 mm SL), Quiribana rivulet, near Caicara, Orinoco basin. MCNG 1028, 2 (33.1-34.0 mm SL), Tierra Blanca

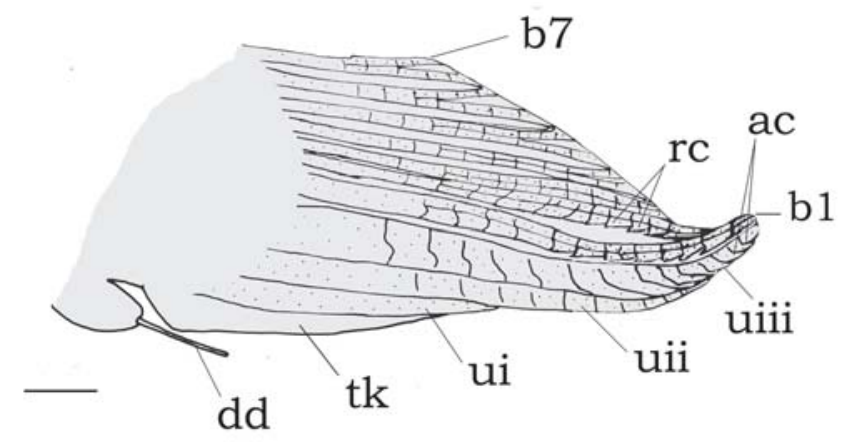

Fig. 24. Male modified anal fin of Tatia galaxias, MCNG 25983, 85.6 mm SL. Left side lateral view. Abbreviations: ac, antrorsely curved denticulation; b1, branched first ray; b7, branched seventh ray; $\mathbf{d d}$, deferent duct; $\mathbf{r c}$, retrorsely curved denticulation; tk, tegumentary keel; ui, unbranched first ray; uii, unbranched second ray; uiii, unbranched third ray. Scale bar $=1.0 \mathrm{~mm}$. rivulet, Km 82 on road Santa Elena. MCNG 16632, 2 (43.3-64.0 $\mathrm{mm}$ SL), Las Claritas river Km 85 on road Santa Elena. MCNG 15595, 1 (57.0 mm SL), Sacuima river, via Caicara-Pijiguaos. MCNG 15970, 1 (39.0 mm SL), Chaviripa river. MCNG 23254, 1 (44.8 mm SL), Quebrada, close to C. Serapia del Nichare river; MZUSP 44072 , 2 (68.5-72.3 mm SL), Cocniza rivulet, tributary of Orinoco river, near Caicara del Orinoco. Guarico: INHS 61870, 5 (20.5-29.5 mm SL) Guariquito river near Aguas Muertes, Parque Aguaro-Guariquito. INHS 61940, 3 (24.4-25.0 mm SL) San Bartolo river. INHS 69420, 4 (22.8-30.0 mm SL) San Bartolo river west from La Esperanza. MCNG 1914, 3 (31.4-32.5 mm SL) Aguaro river in Hato San Jose. MCNG 15001, 3 plus 1CS (25.3-29.4 mm SL) San Bartolo river, Parque Aguaro. MCNG 17137, 1 (28.3 mm SL) rivulet in Hato Batolena. MCNG 17138, 2 (25.1-32.2 mm SL) San Bartolo river, Parque Aguaro. Monagas: RMNH 30502, 1 (31.0 mm SL) Guarapiche river. USNM 265661, 1 (30.0 mm SL) Guarguapo rivulet, about 500 meters upstream from its mouth in Orinoco river, upstream from Barrancas.

\section{Tatia gyrina (Eigenmann \& Allen, 1942)}

Figs. 2-5, 25-26

Centromochlus aulopygius. Eigenmann \& Eigenmann, 1888: 157 [Cudajas (Codajás)]. Eigenmann \& Eigenmann, 1890: 270 [distribution]. Eigenmann \& Eigenmann, 1891: 34 [listing].

Centromochlus gyrinus Eigenmann \& Allen, 1942: 118, pl.5 fig. 4 [type locality: Peru, Iquitos, brook near Itaya river]. Gosline, 1945: 10 [listing]. Fowler, 1945a: 62 [Iquitos]; Fowler, 1945b: 112 [listing]; Fowler, 1951: 462, fig. 491 [literature compilation].

Centromochlus creutzbergi Boeseman, 1953: 7, fig. 1c [type locality: Djaicreek (Djao stream)]. New synonym. -Hoedeman, 1957:151, fig. 8 [Coropina stream near Republiek].Rössel, 1962: 30 [no locality].-Hoedeman, 1968: 148 [Suriname].

Tatia gyrina. Mees, 1974: 74-75 [notes on holotype and distribution]. Ortega \& Vari, 1986:14 [reference]. Burgess, 1989:242 [reference]. Soares-Porto, 1995:205 [citation]. Soares-Porto, 1998: 333 [citation]. Ferraris, 2003:477 [checklist]. Ferraris, 2007: 77 [checklist].

Tatia creutzbergi. Mees, 1974: 77-80, fig. 18 [notes and distribution, northern Suriname lowlands and Cudajas (=Codajás), Brazil]. Sands, 1984: 40 [listing]. Mees, 1985: 241 [northern Suriname]. Mees, 1988: 410 [Para stream and Kaboeri stream, Suriname]. Burgess, 1989:242 [reference]. Soares-Porto, 1995:205 [citation].Chang \& Ortega, 1995:4 [reference]. Soares-Porto, 1998: 333 [citation]. Ferraris, 2003:476 [checklist]. Ferraris, 2007: 77 [checklist].

Diagnosis. Tatia gyrina is distinguished from all other species of Tatia by its reduced mesethmoid, wider than long, (mesethmoid length 12.1-15\% HL; width 17.2-19\% HL); lower jaw slightly protruding beyond upper; nasal ossified, tubular, not sutured to mesethmoid; third nuchal plate reduced (Fig. 3, n3); small prevomer, with short rostro-lateral process; elongate postcleithral process, sometimes as long as head length; ribs 5-6 (vs. 7-11 in other Tatia); and vertebrae, 29-30 
(vs. 31-39 in other Tatia, except T. galaxias, that rarely has 30). Mature males have an externally elongate deferent duct and a swollen anal-fin base, with a thick secretory pouch (Fig. 26, tp). The species is also distinguished by the following combination of restricted characteristics: females with genital papilla; anal fin of mature males bearing rays with uncurved segments; and caudal fin lobes with about the same length in both adult females and males. Additional features useful for distinguishing T. gyrina has a whitish ground color pattern with brown spots, pattern mottled or with irregular stripes; ventral surface of head covered with short brown irregular stripes; body with a characteristic dark band along lateral line; and a small adult size of less than $40 \mathrm{~mm}$ SL.

Description. Measured adult specimens 28.0-38.2 mm SL; morphometric data presented in Table 8. Body short, head slightly depressed dorso-ventrally. Head large, robust, out- line of head in dorsal view somewhat rectangular, broader than long. Dorsal outline of trunk from dorsal-fin base to caudal peduncle gradually compressed posteriorly. Lateral profile of head from snout tip to above opercular margin slightly convex until pectoral-fin insertion. Ventral profile of head and abdomen flat. Ventral profile of body concave posterior to anal fin.

Head integument thin, cranial roof visible; well-developed adipose eye lid; eye latero-dorsally located in anterior portion of head; mouth terminal, lower jaw slightly protruding beyond upper, upper lip extended postero-laterally as well-developed fleshy rictal fold; snout margin rounded, in dorsal view; anterior nostril tubular, located on anterior border of snout; posterior nostril large, rounded, limited by well developed skin flap; transverse distance between anterior nostrils shorter than distance between posterior ones. Maxillary barbel of moderate size, extending beyond opercular membrane, reaching vertical

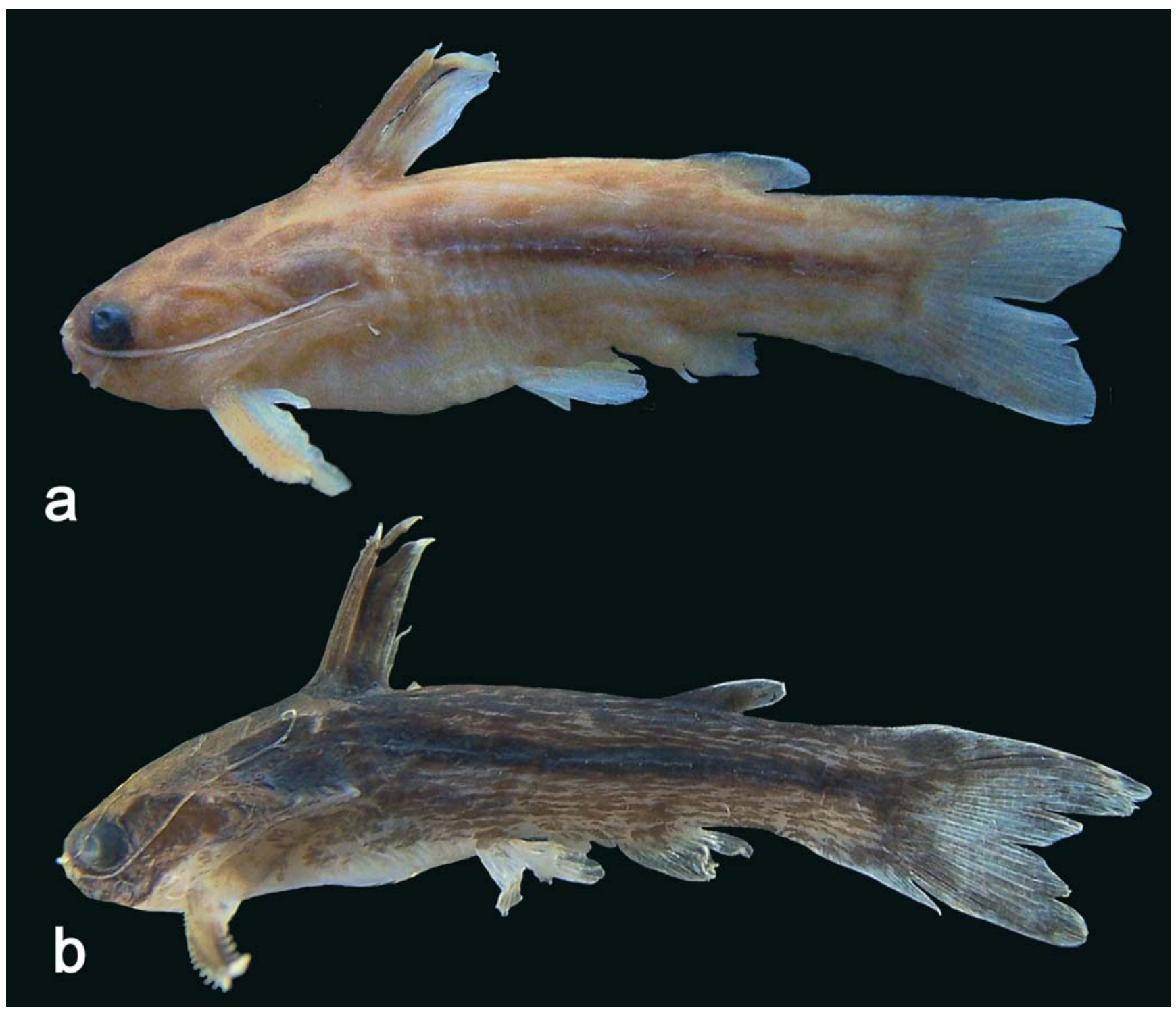

Fig. 25. Tatia gyrina. (a) ZMA 105.859, male, 30.1 mm SL, Carolina stream, Suriname. (b) INPA 20971, female, 26.0 mm SL, Tefé, Amazonas State, Brazil. 
through middle dorsal fin; Four mental barbels, tips not reaching pectoral-fin base, arranged in arc along ventral surface of jaw; inner mental barbel about 50.0-67.0\% length of outer mentals. Postcleithral process well developed, almost reaching vertical through middle or end of dorsal fin. Caudal peduncle moderately deep, its depth about 11.3-13.2\% SL.

Rostral border of cranium thin with small mesethmoid, larger than long; premaxilla underneath with synchondral articulation; cranial fontanel large, rounded, bounded by mesethmoid and frontal (Fig. 2); nasal ossified as short tubular canal bone, lying between mesethmoid cornua and lateral ethmoid, not sutured to mesethmoid; autopalatine tubular, oriented obliquely to longitudinal axis of body; maxilla small, shorter than autopalatine; prevomer reduced, with short lateral process. Discrete prognathous mandibula; premaxilla and dentary with two to three rows of conical teeth. First nuchal plate trapezoid; second nuchal plate short; third nuchal plate short, with tips projected laterally. Epioccipital process very small.

Suspensorium and opercular bones (Fig. 2); hyoid arch (Fig. 4) and branchial skeleton (Fig. 5) as in generic description. Suprapreopercle present as short canal bone. Five to seven slender branchiostegal rays articulated with hyoid arch: three to five with anterior ceratohyal and two with posterior ceratohyal; last one expanded. Basibranchial 2 forming osseous rod with broad cartilaginous anterior tip, separated from shorter basibranchial 3 .

Five to six infraorbital bones in incomplete series. Infraorbital 1 thin, with short ventro-lateral process; remaining infraorbitals thin, reduced to canalicular portions. Infraorbital 2 and/or 3 small, close to infraorbital 1, followed by nonossified portion of canal below eye and two posterior canal bones, forming posterior orbital rim. Lateral line on body with 3-5 ossified canal bones only close to head.

Dorsal fin I,3-5 ( $\mathrm{n}=19)$, usually 4 (three branched only in $T$. creutzbergi holotype and five branched in one AMNH 105.832 specimen). Dorsal-fin spine with 10-15 antrorse serrations along entire anterior margin, posterior margin smooth. Pectoral fin I,4 ( $\mathrm{n}=21)$; pectoral-fin spine with 17-23 antrorse serrations along anterior margin; 9-13 retrorse serrations along posterior margin; serrations along both margins progressively larger towards spine tip. Pelvic fin i,5 $(n=21)$; margin rounded. Adipose fin large, origin on vertical through middle of analfin base. Anal fin ii-iii, 6-7 $(n=21)$; anal-fin pterygiophores in eight rod-like proximal radials and seven cartilaginous distal radials. Caudal fin slightly emarginated, lobes with rounded tips, 8+9 principal rays, 8-20 upper procurrent, 10-21 lower procurrent rays $(\mathrm{n}=21)$. Pleural ribs 5-6 attached to consecutive vertebrae. Post-Weberian vertebrae 29-30 $(n=9)$.

Color in alcohol. Illustration in Eigenmann \& Allen (1942: 439, fig. 4), shows holotype of $T$. gyrina as originally mottled brown, without dark lateral band, and specimen described as spotted and streaked (Eigenmann \& Allen, 1942: 118). Preserved holotype now faded and, based on recent examination of specimen, has only traces of pigmentation, consisting of small brown chromatophores on dorsal and caudal fins.
Species coloration described as follows (Fig. 25): Dorsal surface of head and dorsal fin dark brown; head irregularly striped in brown ventrally; sides of body mottled with numerous irregular spots; usually dark brown stripe along lateral line; body usually yellowish ventrally; pectoral-fin spine usually with transverse dark bands; adipose fin pale brown; caudal fin spotted with dark band on center of each lobe. Sands (1984: 40) illustrated a living specimen of T. gyrina.

Color variation. Variation in body pigmentation was observed between the Suriname and Amazonian populations. In Suriname specimens the body is usually yellowish ventrally or sometimes with a rounded brown spot present near each pelvic-fin base. No Amazon specimens had a rounded brown spot near the pelvic-fin base and the body is invariably yellowish ventrally. Variation in pectoral-fin spine pigmentation occur independent of geographical locality: pectoral-fin spine is usually transversely banded but is uniformly dark to unpigmented in some specimens. Coloration of the dark lateral stripe on the side of the body varies. In some Suriname specimens (ZMA 105.832) the dark brown lateral stripe has irregular dark and light areas. In addition, the lateral stripe was interrupted in some and absent in decolorized specimens. In

Table 8. Morphometric data for Tatia gyrina. $\mathrm{SD}=$ standard deviation.

\begin{tabular}{|c|c|c|c|c|}
\hline & Range & Mean & SD & $\mathrm{N}$ \\
\hline Standard length & $28.0-38.2$ & 29.2 & & 22 \\
\hline \multicolumn{5}{|c|}{ Percents of standard length } \\
\hline Body depth & $20.2-25.4$ & 22.5 & 1.53 & 22 \\
\hline Body width & $24.0-27.1$ & 25.6 & 0.79 & 22 \\
\hline Caudal peduncle depth & $11.3-13.2$ & 12.6 & 0.77 & 22 \\
\hline Caudal peduncle length & $24.3-29.9$ & 26.9 & 1.44 & 21 \\
\hline Predorsal length & $33.0-41.1$ & 36.8 & 2.17 & 22 \\
\hline Preanal length & $58.1-77.2$ & 65.9 & 3.80 & 22 \\
\hline Prepelvic length & $48.1-53.8$ & 50.1 & 1.74 & 22 \\
\hline Dorsal origin to pectoral origin & $26.5-32.1$ & 28.8 & 1.69 & 22 \\
\hline Dorsal origin to pelvic origin & $26.6-33.3$ & 29.8 & 1.69 & 22 \\
\hline Pectoral origin to pelvic origin & $30.7-35.6$ & 33.0 & 1.69 & 22 \\
\hline Prepectoral length & $19.7-25.7$ & 22.6 & 1.79 & 22 \\
\hline Dorsal-fin base length & $7.3-12.8$ & 10.3 & 1.47 & 22 \\
\hline Adipose-fin base length & $11.2-19.4$ & 14.4 & 2.01 & 22 \\
\hline Anal-fin base length & $3.6-12.4$ & 8.4 & 2.70 & 22 \\
\hline Dorsal-fin spinelength & $19.6-26.0$ & 21.8 & 1.55 & 22 \\
\hline Pectoral-fin spine length & $23.1-31.4$ & 27.2 & 1.82 & 22 \\
\hline Postcleithral process lenght & $20.6-26.9$ & 24.1 & 1.80 & 22 \\
\hline First branched pelvic-fin ray & $11.7-18.0$ & 13.8 & 1.49 & 22 \\
\hline Longest anal fin ray & $7.6-14.4$ & 10.8 & 1.73 & 22 \\
\hline Maxillary barbel length & $30.8-38.8$ & 35.0 & 2.10 & 22 \\
\hline Outer mental barbel length & $9.6-12.8$ & 11.2 & 0.91 & 22 \\
\hline Mental barbel length & $5.0-8.5$ & 6.0 & 0.84 & 22 \\
\hline Head length & $22.8-28.5$ & 25.4 & 1.53 & 22 \\
\hline \multicolumn{5}{|c|}{ Percents of head length } \\
\hline Head width & $82.4-94.2$ & 86.8 & 3.31 & 22 \\
\hline Snout depth & $50.0-59.4$ & 53.8 & 2.95 & 21 \\
\hline Interorbital distance & $58.0-75.6$ & 65.0 & 6.67 & 22 \\
\hline Left internarial width & $18.6-25.0$ & 21.1 & 1.78 & 21 \\
\hline Anterior Internarial distance & $33.8-44.1$ & 38.8 & 3.17 & 21 \\
\hline Posterior internarial distance & $42.7-51.6$ & 47.1 & 2.41 & 21 \\
\hline Snout length & $37.0-45.8$ & 41.3 & 2.53 & 22 \\
\hline Orbital diameter & $21.3-30.0$ & 25.0 & 2.86 & 22 \\
\hline Mouth width & $40.2-61.9$ & 53.6 & 7.72 & 22 \\
\hline
\end{tabular}


an upper Amazon specimen (FMNH 94752), the lateral stripe is light brown, not as dark as in the Amazon specimens.

Tatia gyrina occasionally occur together with $T$. strigata and in these situations the two species are remarkably similar in appearance. The situation is exacerbated by the fact that $T$. strigata taken with $T$. gyrina have a dark lateral stripe, a character otherwise rare in T. strigata. In these instances, the main way to distinguish the two species is by certain head measurements. Tatia gyrina has a deep (snout depth 50.0$59.4 \% \mathrm{HL}$ ), and broad head (head width $82.4-94.2 \% \mathrm{HL}$ ) and prognathous lower jaw; whereas $T$. strigata has a shallow (snout depth 41.3-47.3\% HL) and narrow head (head width $70.1-76.7 \% \mathrm{HL}$ ), and jaws of equal sizes. There are also some minor color differences. The sides of body in $T$. gyrina are mottled, with variations in form and size of the individual spots, but never striated or striped like in T. strigata. Furthermore in T. strigata the stripes are long, almost horizontal and narrow.

Sexual dimorphism. Based on examination of gonads, $T$. gyrina attains sexual maturity above $28.0 \mathrm{~mm}$ SL. In mature females a genital papilla is evident, with the genital opening close to the anal-fin origin, emerging from a slender fleshy process. A female genital papilla is rare within Tatia. The genital papilla of mature male is evidenced by a swollen anal-fin base (Fig. 26). Dissection revealed the presence of a thick pouch inside it, formed by broad mass of some glandular tissue, with secretory material. A unique male deferent duct is present, externally elongate, thick and emergent (Fig. 26, dd). The extended deferent duct is also seen in young males, permitting the distinction between sexes even in juveniles. This condition is uniquely found in T. gyrina males. In other Tatia, as well as in most centromochlins, only short slender tip of deferent duct is externally visible, emerging from genital papilla.

The mature male modified anal fin (Fig. 26) is short, with a small tip, and three enlarged and thickened unbranched analfin rays. First unbranched ray with the segments fused or bearing a single median one in one specimen (CAS 36979), and is immediately preceded by a short tegumentary keel (Fig. $26, \mathrm{tk})$. The second and third unbranched rays are converging with first branched to form a short anal-fin tip (Fig. 26, uiii). No curved segments are associated with the anterior rays. The posterior branched rays are normally developed, with the last ray not reduced (Fig. 26, b7).

Hemal spines 13-16 interdigitate with the anal-fin pterygiophores, being the hemal spines 14-16 thickened in mature males, but undifferentiated in females. Minor sexual dimorphism is observed in male caudal fin: upper lobe of some males is slightly elongate, about $10 \%$ longer than lower one. The caudal-fin lobes have same length in mature females.

Distribution. Tatia gyrina occurs in the upper and central Amazon, in Peru, Colombia and Brazil. It is also found in rivers of northern Suriname (Fig. 6).

Remarks. This species was originally described by Eigenmann
\& Allen (1942) as Centromochlus gyrinus based on a single specimen from Iquitos, Peru. Nearly a decade latter, Boeseman (1953) described Centromochlus creutzbergi based on a specimen from Suriname, but without a comparison to Centromochlus gyrinus. Mees (1974) transferred both species to the genus Tatia, based on similarities in fin ray counts and the shape of adipose fin. For many years the Amazonian $T$. gyrina was known only from its holotype. The holotype of $T$. gyrina is old and has lost its color. The specimen, however, is a mature male, with a modified anal fin that is similar in appearance to the anal fin of specimens from Suriname identified as $T$. creutzbergi. Recent sampling of Amazon igarapés has made available more specimens, including adults, what has allowed for a more detailed morphological comparison of Amazon and Suriname populations. The new material indicates that $T$. creutzbergi from Suriname and T. gyrina from the Amazon are morphologically very similar and hereby considered conspecific under the older name T. gyrina. Differences generally associated with color pattern and certain head proportions are considered intraspecific geographic variation. Both have the same general coloration, a conspicuous dark lateral stripe and mottling on sides of body. In the Amazon populations, however, the dark stripe is interrupted in some specimens, whereas in all Suriname specimens examined the dark stripe is always present and conspicuous. In some Suriname specimens the pelvic-fin base has a characteristic darkened area, with paired brown spots. These markings are especially obvious in specimens recently captured. Some Suriname specimens have the ventral surface of body uniformly whitish, (ZMA 105.829), in the same way as Amazon specimens. The low number of vertebrae, 29 in Amazonian catfishes ( $\mathrm{n}=3$ ), and 30 in Suriname ones $(\mathrm{n}=6)$, was counted in some specimens only, and overlap of counts may occur. The Amazon and Suriname populations of T. gyrina also exhibit a few differences regarding head proportional measurements: head slightly broader and deeper in Amazon specimens, $88.8-94.2 \%$ and $56.3-59.4 \% \mathrm{HL}$, respectively (vs. narrower and shallower in Suriname, 82.4-86.7\% and 50.0$55.4 \%$ HL, respectively); and mouth wider in Amazon specimens, 56.6-61.9\% HL (vs. narrower in Suriname 40.2-45.6\% HL). Regional differences in head measurements and vertebral counts are interpreted as intraspecific variation within $T$. gyrina.

Tatia gyrina is typically associated with blackwater environments, mainly in rivers. In the central Amazon, populations of $T$. gyrina were found in both black- and clear-waters, but only in dense vegetation where there is little light ( $\mathrm{J}$. Zuanon, pers. comm.). Available field data indicate these catfish typically occur in water with low $\mathrm{pH}$, low conductivity and low level of dissolved oxygen (J. Zuanon, pers. comm.; H. Nijssen, field notes).

Material examined. 80 specimens (23.6-38.2 mm SL). Holotype. Peru: Loreto: CAS 36979, 1 (42.0 mm SL), tributary of Itaya river, above Iquitos (holotype of Centromochlus gyrinus). Suriname: RMNH 19440, 1 (R) (25.2 mm SL), Djaicreek (holotype of Centromochlus creutzbergi). Non-type specimens. Brazil: Amazonas: MCZ 8182, 1 (32.7 mm SL), Brazil: Amazonas: Solimões river in Codajás. INPA 18478, 1 (38.2 mm SL), Brazil. Amazonas: 
Tefé. INPA 20970, 2 (29.0-36.2 mm SL), Tefé, reserva desenvolvimento sustentável Amanã, igarapé Branco. INPA 20971, 4, 1 CS (26.0-28.3 mm SL), Tefé: reserva de desenvolvimento sustentável Amanã, igarapé do Veado. INPA 20972, 1 (35.1 mm SL). Colombia: FMNH 94752, 1, Ti river. Suriname: AMNH 58389, 2 (28.6-29.7 mm SL), Carolina stream. RMNH 28616, 5 (R) (31.0-33.0 mm SL), Sipaliwini: upper Nickerie river; RMNH 28617, 10 (1 CS) (25.0-34.1 mm SL), Sipaliwini: tributary on right margin of Nickerie river, above Stondansie Camp; RMNH 28618, 8 (31.2-35.0 mm SL), tributary on right margin of Fallowatra river, Nickerie river basin; RMNH 28619, 7 (26.3$34.0 \mathrm{~mm} \mathrm{SL}$ ), Forest stream, above Stondansie, Nickerie river basin; RMNH 28620, 14 (30.4-37.2 mm SL), tributary on left margin of Nickerie river, above Blanche Marie falls; RMNH 28621, 1 (34.7 mm SL), small tributary of middle Maratakka river; RMNH 28622, 2 (28.2-30.0 mm SL), Winanna river; RMNH 28623, 2 (14.5-21.0 mm SL), tributary of Kabalebo stream, below Avanavere falls; RMNH 30540, 1 (26.2 mm SL), Kaboeri stream; ZMA 105.523, 1 (39.0 mm $\mathrm{SL})$, Gran Mau stream, right margin of the Gran river, $1 \mathrm{~km}$ northwestern from Village Dombaai; ZMA 105.657, 1 (33.6 mm SL), Saramacca river; ZMA 105.832, 4 (27.4-33.6 mm SL), Nickerie river; ZMA 105.859, 10 (1 CS) (23.1-30.1 mm SL), Para: Carolina stream.

\section{Tatia intermedia (Steindachner, 1877)}

Figs. 27-29

Centromochlus aulopygius. Günther, 1864 [Essequibo]. Eigenmann \& Eigenmann, 1891: 34 [in part, Essequibo]. Eigenmann, 1910: 395 [Essequibo]. Eigenmann, 1912: 197, pl. 20 fig. 1 [stream below Potaro Landing, Wismar; Guyana]. Puyo, 1949: 97 [streams on region of Approuage]. Miranda Ribeiro, 1962: 9 [Araguaia river, Aruanã, Goiás].

Centromochlus intermedius Steindachner, 1877: 664, footnote [type locality: Marabitanos, Pará]. Fisher, 1917: 422 [in part, Tapajós river at Santarém].

Centromochlus perugiae. Vaillant, 1899: 155 [Lunier or Carnot river, tributary of the Carsevenne, now Calçoene, Amapá]; Vaillant, 1900: 124, 127 [Carnot river].

Tatia intermedia. Miranda Ribeiro, 1911: 360 [generic designation, assignment to Tatia, in part, Marabitanos]. Mees, 1974: 59-63 [notes and distribution, in part, Pará]. Sands, 1984: 37 [listing]. Kobayagawa, M. 1991:104 [reference]. Soares-Porto 1995:204 [citation]. Soares-Porto, 1998: 349 [citation]. Ferraris, 2003:477 [checklist]. Ferraris, 2007: 77 [checklist].

Tatia aulopygia. Gosline, 1945: 10 [in part, Essequibo]. Fowler, 1951: 470 [Guyana]. Lowe Mc Connell, 1964: 116, 141 [Simoni stream, Rupununi, Guyana]. Mees, 1974: 59-63, fig. 11. [in part, Suia Missu, Mato Grosso]. Sands, 1984: 38-39 [Xingu river]. Burgess, 1989: 242 [northeastern South America]. Soares-Porto, 1995:205 [citation], Soares-Porto, 1998:333 [citation].

Centromochlus. Lowe-McConnell, 1987: 282, fig. 12.2 d.

Diagnosis. Tatia intermedia is distinguished by the following combination of characteristics: wide elliptical cranial fontanel; short postcleithral process not reaching vertical through origin of dorsal fin; body coloration variable, usually with elliptical spots along sides of body, large specimens with faint spots; or color pattern uniformly pale brown; caudal fin with small spots or pale brown. The only other Tatia with a variable coloration is $T$. galaxias. Tatia intermedia differs from $T$. galaxias by its short postcleithral process ( $v s$. long in T. galaxias); its small eye, $21.4-26.3 \% \mathrm{HL}$ (vs. $37.0-42.9 \%$ in $T$. galaxias) and its long snout $38.8-44.3 \%$ HL (vs. $23.1-28.9 \%$ in T. galaxias). Additional features useful for distinguishing $T$. intermedia include: nasal ossified with wide medial flanges partially sutured to lateral margin of mesethmoid; caudal-fin lobes of mature females with same length, but mature males with elongated upper lobe.

Description. Measured specimens 50.4-91.2 mm SL; morphometric data presented in Table 9. Body slim, head slightly depressed dorso-ventrally. Head large, robust, outline of head in dorsal view somewhat elliptial, broader than long. Trunk from dorsal-fin base to caudal peduncle becoming gradually compressed laterally. Lateral profile of head from snout tip to above opercular margin slightly convex until pectoral-fin insertion. Ventral profile of head and abdomen flat. Ventral profile of body gently curved, concave behind anal fin origin.

Head integument thin, cranial roof visible; well-developed adipose eye lid; eye latero-dorsally located in anterior portion of head; mouth terminal, upper lip extended posterolaterally as well-developed fleshy rictal fold; anterior nostril tubular, located on anterior border of snout; posterior nostril large, rounded, limited by small skin flap; transverse distance between anterior nostrils proportionally the same as distance between posterior ones. Maxillary barbel short, almost reaching vertical through origin of dorsal fin; mental barbel short, tips not reaching pectoral-fin base, arranged in arc along ventral surface of jaw; inner mental barbel about 55.0-65.0\% length of outer mentals. Postcleithral process short, not reaching vertical through origin of dorsal fin. Caudal peduncle deep, depth about $13.9-18.1 \%$ SL.

Rostral border of cranium broad with large mesethmoid; premaxilla underneath with synchondral articulation; cranial fontanel large, elliptical, bounded by mesethmoid and frontal (Fig. 28); nasal ossified, with medial flanges sutured to lateral margin of mesethmoid; autopalatine tubular, oriented obliquely

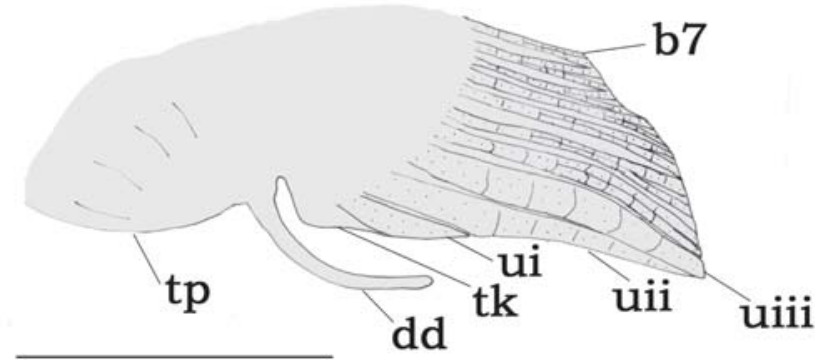

Fig. 26. Male modified anal fin of Tatia gyrina, INPA 20971, $28.0 \mathrm{~mm}$ SL. Left side lateral view. Abbreviations: b7, branched seventh ray; dd, deferent duct; tp, thick secretory pouch; tk, tegumentary keel; ui, unbranched first ray; uii, unbranched second ray; uiii, unbranched third ray. Scale bar $=1 \mathrm{~mm}$. 
to longitudinal axis of body; maxilla small, shorter than autopalatine. Prevomer expanded anteriorly with well developed arrow-shaped lateral processes, bearing small teeth attached to process in examined large specimens ( $>74 \mathrm{~mm} \mathrm{SL})$. Jaws of equal size; premaxilla and dentary with three to four rows of conical teeth. First nuchal plate somewhat pentagonal; second nuchal plate concave along lateral margins; third nuchal plate curved, projected laterally. Epioccipital process very small.

Suspensorium, hyoid arch, opercular bones and branchial skeleton as in generic description. Suprapreopercle present as short robust canal bone. Six branchiostegal rays articulated with hyoid arch: four with anterior ceratohyal and two with posterior ceratohyal; last one largest and laminar expanded.

Five infraorbital bones in incomplete series. Infraorbital 1 thin, with short ventro-lateral process on anterior border of eye; remaining infraorbitals thin, reduced to canalicular portions. Infraorbital 2 smallest, close to infraorbital 1, followed by non-ossified portion of canal below eye and three posterior ossicles bordering eye posteriorly: last one in contact to sphenotic. Lateral line on body with ossified canal bones posteriorly to vertical through pelvic fin origin.

Dorsal fin I,4-5 ( $\mathrm{n}=12)$; dorsal-fin spine with 12-17 antrorse serrations along entire anterior margin, posterior margin smooth. Pectoral fin I,5 ( $\mathrm{n}=12)$, pectoral-fin spine with 14-17

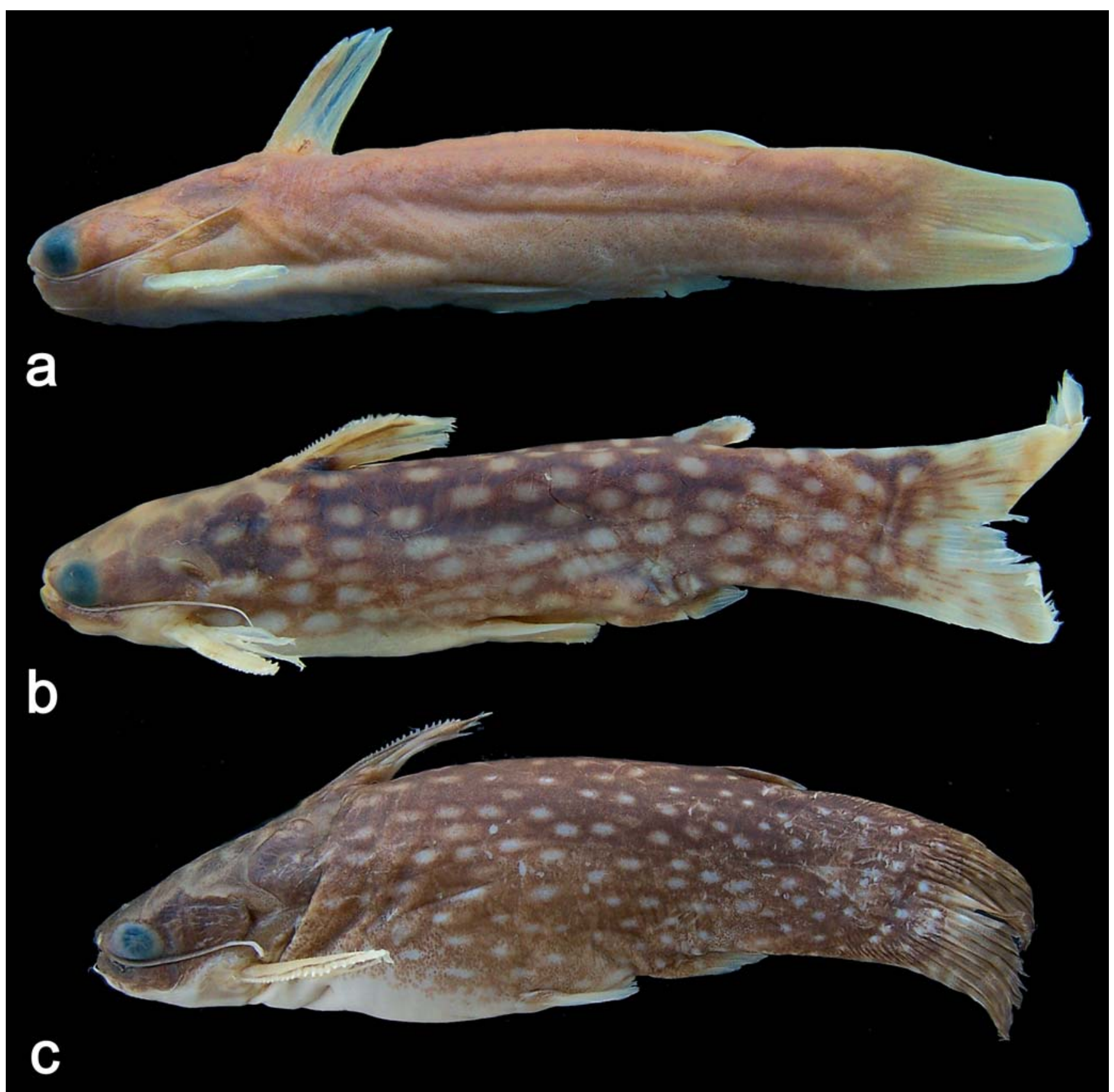

Fig. 27. Tatia intermedia. (a) MZUSP 44255, male, $65.5 \mathrm{~mm}$ SL, Capim river, Pará State, Brazil. (b) ZMA 105.523, male, $39.0 \mathrm{~mm}$ SL, Gran Mau stream, Suriname. (c) INPA 11076, female, $84.7 \mathrm{~mm}$ SL, Tocantins river, Pará State, Brazil. 
antrorse serrations along anterior margin; $11-16$ retrorse serrations along posterior margin; serrations along both margins become progressively larger towards spine tip. Pelvicfin i,5 $(n=12)$; margin rounded. Adipose fin small, origin on vertical through end of anal-fin base. Anal fin iii, 6-7 ( $\mathrm{n}=12)$; anal-fin pterygiophores in eight rod-like proximal radials and seven cartilaginous distal radials. Caudal fin forked, lobes with rounded tips, $8+9$ principal rays, 10-16 upper procurrent, 15-22 lower procurrent rays $(\mathrm{n}=12)$. Pleural ribs 10 attached to consecutive vertebrae. Post-Weberian vertebrae 35-36 ( $\mathrm{n}=5)$.

Color in alcohol. In the original description of Centromochlus intermedius, Steindachner (1877) did not mention the color pattern of the two syntypes. Steindachner (1881) noted a copper-colored body with regular spots and a silver gray caudal fin in specimens from Jutaí and Jutuarana, Amazon basin, when comparing those specimens with the syntypes. Only one decolorized syntype of $C$. intermedius (NMW 47355) was available for our examination. As the original color pattern for the syntypes was not clearly stated in species description, specimens from Marabitanos, the type locality, possibly were uniformly light brown. This is in agreement with the color pattern found in specimens from the Capim river, eastern Pará (Fig. 27a). Specimens from eastern Pará have the dorsal surface of the head and dorsal mid-line brown, the sides usually dark brown, the ventral contour of the head around the chin, lips and anterior nostrils brown, the body whitish ventrally, the dorsal fin with a dark base and irregular spots towards the fin tip, the pectoral, pelvic and adipose fins hyaline, and the caudal fin pale brown.

Color variation. Geographical and individual variation in coloration was observed throughout the distribution of $T$. intermedia. Besides the coloration in eastern Pará specimens (Fig. 27a), other patterns are found. In specimens from Amapá, Suriname and Guyana the common pattern is the presence of large light ellipsoid spots on dorsum and sides of body to caudal-fin tips; pale nuchal shield; and pectoral fin usually with transverse dark bands (Fig. 27b).

In the lower Amazon and upper Tocantins some specimens have a light brown body coloration and spotted caudal fin. In the upper Tocantins river drainage specimens usually have small light spots over the body becoming smaller towards the caudal-fin tip, a dark nuchal shield, and the pectoral fin usually light brown (Fig. 27c). Sometimes specimens with a spotted body and caudal fin co-occur with specimens having a uniformly light brown body and spotted caudal fin. In some localities specimens with light brown bodies may have the caudal fin spotted or plain light brown.

Differences in overall intensity of pigmentation were observed relative to size. In some very young specimens, less than $20 \mathrm{~mm} \mathrm{SL}$, the spots are vivid and sharply defined compared to some large specimens (up to $70 \mathrm{~mm} \mathrm{SL}$ ), wherein the spots are pale and poorly defined. The thick superficial skin layer obscures the coloration pattern in large T. intermedia, as is seen among other large sized Tatia.
Sexual dimorphism. Based on examination of gonads, $T$. intermedia attains sexual maturity above $50.4 \mathrm{~mm}$ SL. In mature females a genital papilla is not evident. A thick genital papilla is visible in mature males, with a short deferent duct. The anal fin of mature male (Fig. 29) is strongly modified, with the anterior rays enlarged and thickened. The first unbranched ray have segments fused, immediately preceded by a large tegumentary keel (Fig. 29, tk). The second unbranched ray is elongated coalescing with the subsequent, third, ray. The third unbranched plus first branched are the longest rays, forming a pointed tip. The distal segments are antrorsely curved (Fig. 29, ac) on third unbranched ray. First and second branched rays with small retrorsely curved distal segments along outer margin (Fig. 29, rc). Posterior branched rays are progressively shorter, with the last ray not reduced (Fig. 29, b6).

Hemal spines 16-19 interdigitating with the anal-fin pterygiophores; being the hemal spines 17-19 thickened in mature males, but undifferentiated in females. Caudal-fin lobes with the same length in mature females; in mature males the upper lobe is more elongated.

Distribution. Originally described from the Amazon basin, $T$. intermedia is the most widely distributed member of the ge-

Table 9. Morphometric data for Tatia intermedia $. \mathrm{SD}=$ standard deviation.

\begin{tabular}{|c|c|c|c|c|}
\hline & Range & Mean & SD & $\mathrm{N}$ \\
\hline Standard length & $50.4-91.2$ & 64.3 & & 12 \\
\hline \multicolumn{5}{|c|}{ Percents of standard length } \\
\hline Body depth & $16.3-22.9$ & 18.3 & 2.13 & 12 \\
\hline Body width & $18.8-22.2$ & 21.1 & 1.14 & 12 \\
\hline Caudal peduncle depth & $13.9-18.1$ & 15.4 & 1.50 & 12 \\
\hline Caudal peduncle length & $23.4-29.0$ & 26.1 & 1.83 & 12 \\
\hline Predorsal length & $28.0-34.1$ & 31.2 & 1.71 & 12 \\
\hline Preanal length & $65.0-69.4$ & 67.0 & 1.95 & 12 \\
\hline Prepelvic length & $47.0-51.7$ & 49.8 & 1.61 & 12 \\
\hline Dorsal origin to pectoral origin & $20.0-25.1$ & 23.1 & 1.41 & 12 \\
\hline Dorsal origin to pelvic origin & 26.3-32.9 & 28.8 & 2.06 & 12 \\
\hline Pectoral origin to pelvic origin & $30.8-36.0$ & 32.9 & 1.66 & 12 \\
\hline Prepectoral length & $17.1-22.6$ & 20.4 & 1.79 & 12 \\
\hline Dorsal-fin base length & $8.8-13.7$ & 10.3 & 1.45 & 12 \\
\hline Adipose-fin base length & $10.2-14.3$ & 12.3 & 1.31 & 12 \\
\hline Anal-fin base length & $6.0-10.6$ & 8.5 & 1.96 & 12 \\
\hline Dorsal-fin spine length & $15.0-20.4$ & 17.7 & 1.42 & 12 \\
\hline Pectoral-fin spine length & $19.3-26.0$ & 23.3 & 1.62 & 12 \\
\hline Postcleithral process lenght & $16.1-18.9$ & 16.2 & 1.63 & 12 \\
\hline First branched pelvic-fin ray & $11.7-14.7$ & 13.2 & 0.75 & 12 \\
\hline Longest anal fin ray & $6.7-11.5$ & 9.8 & 1.45 & 12 \\
\hline Maxillary barbel length & $28.9-34.1$ & 31.8 & 1.89 & 12 \\
\hline Outer mental barbel length & $6.9-11.5$ & 9.1 & 1.25 & 12 \\
\hline Mental barbel length & $4.6-6.3$ & 5.4 & 0.61 & 12 \\
\hline Head length & $19.6-25.5$ & 22.9 & 1.46 & 12 \\
\hline \multicolumn{5}{|c|}{ Percents of head length } \\
\hline Head width & $79.7-92.5$ & 85.8 & 4.27 & 12 \\
\hline Snout depth & $48.7-49.7$ & 49.3 & 0.29 & 12 \\
\hline Interorbital distance & $60.1-63.6$ & 61.5 & 1.38 & 12 \\
\hline Left internarial width & $20.8-26.0$ & 22.7 & 1.80 & 12 \\
\hline Anterior internarial distance & $41.1-47.1$ & 44.4 & 2.00 & 12 \\
\hline Posterior internarial distance & $40.8-46.5$ & 42.9 & 1.82 & 12 \\
\hline Snout length & $38.8-44.3$ & 42.0 & 1.80 & 12 \\
\hline Orbital diameter & $21.4-26.3$ & 24.4 & 1.92 & 12 \\
\hline Mouth width & $50.0-55.0$ & 52.8 & 1.82 & 12 \\
\hline
\end{tabular}


nus. It occurs in the upper reaches of the Araguaia, Tocantins, Xingu, and Capim rivers, tributaries of the lower Amazon of Brazil, northwards to the Suriname coastal rivers and the Essequibo river in Guyana (Fig. 6).

Remarks. Recognition of $T$. intermedia remained difficult for a long time. Mees (1974: Fig. 11) mistakenly associated the specimens from Suia Missu river in Mato Grosso, Brazil, as $T$. aulopygia. Mees' specimens were young, bearing small spots over the body, and their coloration conforms with that observed for other $T$. intermedia. Tatia intermedia and $T$. aulopygia are compared under the redescription of $T$. aulopygia.

The pectoral-fin spine with transverse bands was considered distinctive for T. intermedia by Soares-Porto (1998). Herein this feature is considered variable, as in some populations the spine is barred, some not. Soares-Porto (1998: 341) considered a barred spine as a derived feature shared between T. intermedia and T. brunnea, but such a condition varies intraspecifically in both species.

Some large $T$. intermedia may be superficially similar to large T. dunni, as both species may have faint light spots on the sides of the body. In spite of this similarity, T. intermedia

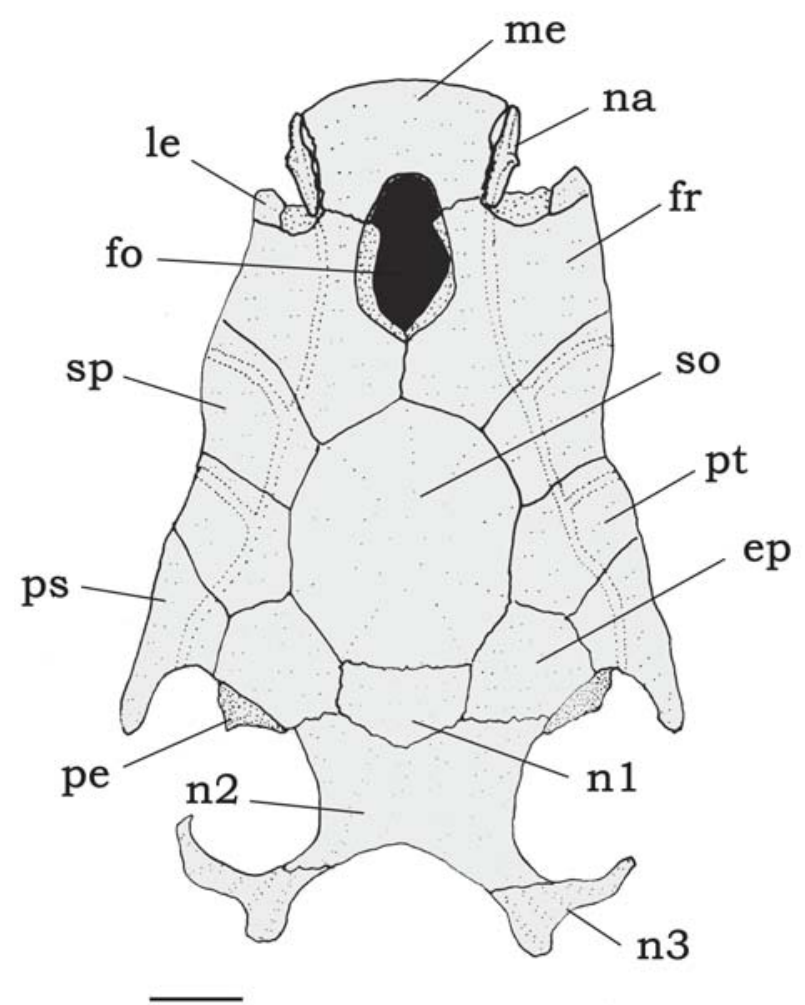

Fig. 28. Neurocranium of Tatia intermedia, MZUSP 44255, $65.5 \mathrm{~mm}$ SL. Dorsal view. Abbreviations: ep, epioccipital; fo, single cranial fontanel, fr, frontal; le, lateral ethmoid; me, mesethmoid; na, nasal; n1, first nuchal plate, n2; second nuchal plate; $\mathbf{n} 3$, third nuchal plate; pe, posterior epioccipital process; ps, posttemporal-supracleithrum; pt, pterotic; so, supraoccipital; sp, sphenotic. Scale bar $=1 \mathrm{~mm}$. differs by having a short postcleithral process, not reaching the vertical through the dorsal-fin origin (vs. long, reaching vertical through dorsal-fin origin in T. dunni); a toothed prevomer in large specimens (vs. edentulous in large T. dunni); and a male modified anal fin with 3-5 elongate antrorse curved segments (vs. 1-3 short antrorse curved segments in T. dunni).

Material examined. 57 specimens (13.1-91.2 mm SL). Syntype. NMW 47355, 1 (R), Brazil: Pará: Marabitanos (syntype of Centromochlus intermedius). Brazil: Amapá: MNRJ 12132, 1 (66.0 $\mathrm{mm}$ SL), Brazil: Amapá: Maruanum river, tributary of Matapi river, Macapá. MNRJ 12133, 1 (31.9 mm SL) and MNRJ 12134, 9 (40.2$65.1 \mathrm{~mm}$ SL), Brazil: Amapá: Aporema river in Fazenda Modelo do Aporema, tributary of Araguari river. Brazil: Goiás: MNRJ 5896, 2 (28.0-66.6 mm SL), Brazil: Goiás: Araguaia river, Aruanã (older Leopoldina). Brazil: Mato Grosso: MZUSP 44256, 2 (29.5-35.2 mm SL), Brazil: Mato Grosso: lake Ipavu, Parque Nacional do Xingu. RMNH 26491, 2 (20.3-31.6 mm SL), Brazil: Mato Grosso: Suia Missu river (=suiá miçú). Brazil: Pará: INPA 2978, 1 (45.4mm SL), igarapé Tucuruizinho, Tocantins river. INPA 11076, 1 (84.7 mm SL), Tocantins river. INPA 21006, 2 (50.4-56.5 mm SL), Trombetas river. MZUSP 9332, 1 (37.3 mm SL), igarapé Ribeira, near Badajós. MZUSP 43250, 15 (19.0-40.0 mm SL), lake Bernardino, near Badajós, Capim river; Km 97. MZUSP 44125, 2 (24.1 mm SL); MZUSP 44255, 5 (29.6-65.3 mm SL), Vila Santana, Capim river. MZUSP 44257, 7 (33.0-48.4 mm SL) and MZUSP 47503, 1, CS, igarapé Caranandena, Capim river. MZUSP 47507, 20 (17.2-49.0 mm SL), lake Maria Preta, Capim river; MZUSP 47508, 1 (40.0 mm SL), igarapé Jari-Mirim, Capim river; MZUSP 50860, 1 (17.2 mm SL), igarapé Canteiro, near Vila Santana, Capim river. MZUSP 44254, 3 (13.1-16.4 mm SL), igarapé Oxipucu, Mocajuba, Tocantins river. MCZ 46032, 1 (20.8 mm SL), Arari river. MZUSP 50861, 1 (24.2 mm SL), Arari river, Arari waterfalls, Marajó island. MCZ 46130, 3 (37.3-40.6 mm SL); MZUSP 43139, 5 (35.2-42.0 mm SL); MZUSP 47504, 1 CS, and RMNH 26492, 1 (40.0 mm SL) igarapé Paracuri, near Icoaraci, Belém. Tocantins: INPA 20042, 1 (58.2 mm SL) Araguari river, locality of Ariranhas in Caseara district. MZUSP 41838, 1 (55.5 mm SL), córrego Jóia, Santa Rita do Araguaia. MZUSP 41422, 1 (57.7 mm SL), Córrego Jacaré, Santa Rita do Araguaia. Suriname. RMNH 26195, 2 (51.3$55.1 \mathrm{~mm}$ SL); RMNH 26199, 12 (38.5-50.0 mm SL), Sipaliwini. RMNH 26201, 1 (27.4 mm SL), stream near aerodrome Käysergebergte. ZMA 105.791, 3 (51.2-74.2 mm SL) (R), stream on left margin of Suriname river, 2,5 km north from Botopasi Village, Brokopondo district. Guyana. AMNH 12947, 1 (72 mm SL), Wismar. AMNH 17643, 1 (91.2 mm SL), Cuyuni river. CAS 24798 , 1 (49.3 mm SL) Wismar river, Demerara, Demerara basin.

\section{Tatia meesi, new species Fig. 30-32}

Holotype. INHS 99772 (44.3 mm SL), Guyana, Potaro-Siparuni: lower Potaro river (Essequibo river Drainage), Waratuk cataract, 05¹5'31.9'N 59²4'01.0'W, 26 Oct 1998, L. M. Page, M. H. Sabaj, J. M. Armbruster, M. Hardman, J. H. Knouft \& W. S. Prince.

Paratypes. Guyana, Potaro-Siparuni: AUM 28140, 14 (27.3-43.1 mm SL); INHS 49549, 9, (1 CS, $43.3 \mathrm{~mm} \mathrm{SL}$ ) (30.3-46.6 mm SL), MBML 2046, 3 (32.2-42.6 mm SL), and MNRJ 28720, 3, (1 CS, 34.0-39.5 $\mathrm{mm} \mathrm{SL}$ ) all collected with the holotype. 
Diagnosis. Tatia meesi is uniquely distinguished from congeners by its coloration: dorsal surface of body, back and upper sides dark-brown sometimes with depigmented area around adipose fin. Cranial fontanel with two narrow openings: anterior one between mesethmoid and frontal and posterior one limited to frontal (Fig. 31). The fontanel apertures are separated from each other through an orbitosphenoid suture beneath frontal. The new species also is distinguished from congeners by a combination of characteristics: nasal ossified as tube, with narrow lateral flange not sutured to mesethmoid; pectoral fin I,4; caudal-fin lobes are the same length in both adult females and males. An additional feature useful for distinguishing T. meesi has the smaller adult size, less than $50 \mathrm{~mm}$ SL.

Description. Measured adult specimens 39.5-46.6 mm SL; morphometric data presented in Table 10. Body slim, head slightly depressed dorso-ventrally. Head robust, outline of head in dorsal view somewhat elliptic, broader than long. Trunk from dorsal-fin base to caudal peduncle becoming gradually compressed laterally. Lateral profile of head from snout tip to opercular margin slightly convex until pectoralfin insertion. Ventral profile of head and abdomen almost straight. Ventral profile of body gently curved, concave behind anal-fin origin. Head integument thin, cranial roof visible; well-developed adipose eye lid; eye latero-dorsally located in anterior portion of head; mouth terminal, upper lip extended postero-laterally as well-developed fleshy rictal fold; snout margin rounded, in dorsal view; anterior nostril tubular, located on anterior border of snout; posterior nostril large, rounded, limited by small skin flap; transverse distance between anterior nostrils proportionally same as distance between posterior ones. Maxillary barbel short, extending close to posterior tip of postcleithral process; mental barbel short, tips not reaching pectoral-fin base, arranged in arc along ventral surface of jaw; inner mental barbel about 51.0-64.0\% length of outer mentals. Postcleithral process long almost reaching

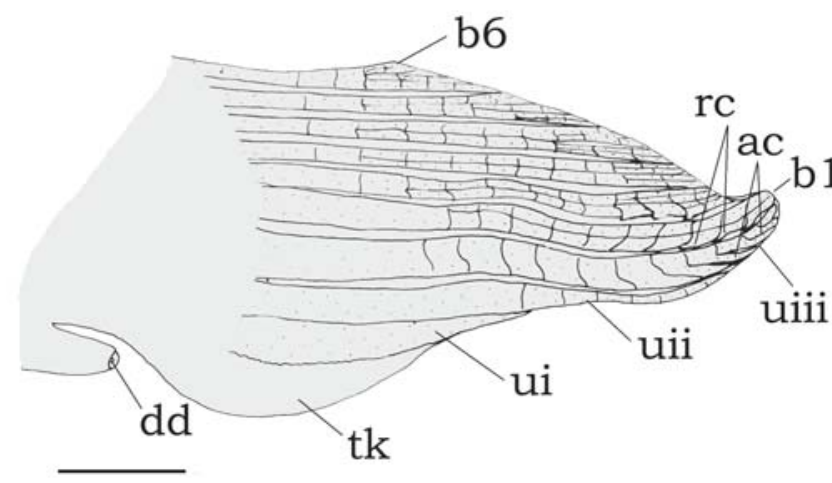

Fig. 29. Male modified anal fin of Tatia intermedia, MZUSP 44255, $65.5 \mathrm{~mm}$ SL. Left side lateral view. Abbreviations: ac, antrorsely curved denticulation; b1, branched first ray; b6, branched sixth ray; dd, deferent duct; rc, retrorsely curved denticulation; tk, tegumentary keel; ui, unbranched first ray; uii, unbranched second ray; uiii, unbranched third ray. Scale bar $=1.0 \mathrm{~mm}$. vertical through middle or end of dorsal fin. Caudal peduncle moderately deep, depth about 10.4-12.3 SL.

Rostral border of cranium with mesethmoid approximately as long as broad; premaxilla underneath with synchondral articulation; elliptical cranial fontanel, with two narrow openings: anterior one between mesethmoid and frontal and posterior one limited to frontal. Fontanel apertures separated to each other by suture beneath frontal, along orbitosphenoid (Fig. 31). Nasal ossified, tubular, with narrow medial flanges, not sutured to mesethmoid; autopalatine tubular, oriented obliquely to longitudinal axis of body; maxilla about same size of autopalatine; prevomer expanded anteriorly, with well developed arrow-shaped lateral processes; jaws of equal size; premaxilla and dentary narrow with two or three rows of conical teeth. First nuchal plate very short, pentagonal; second nuchal plate slightly concave along lateral margins; third nuchal plate curved, projected laterally, with broad tip. Epioccipital process very small.

Suspensorium, hyoid arch, branchial skeleton and opercular bones as in generic description. Suprapreopercle present as short canal bone. Five slender branchiostegal rays articulated with hyoid arch: three or four with anterior ceratohyal and two with posterior ceratohyal; last two flattened. Basibranchial 2 forming osseous rod with a broad cartilaginous anterior tip, separated from shorter basibranchial 3.

Five infraorbital bones in incomplete series. Infraorbital 1 thin with short ventro-lateral process; remaining infraorbitals thin, reduced to canalicular portions. Infraorbital 2 smallest, close to infraorbital 1 , followed by non-ossified portion of canal below eye and two posterior ossicles much close to sphenotic, forming posterior orbital rim. Lateral line on body with ossified canal bones only close to head.

Dorsal fin I,5, dorsal-fin spine with 9-11 antrorse serrations along entire anterior margin, posterior margin smooth. Pectoral fin I,4, pectoral-fin spine with 15-18 antrorse serrations along anterior margin; 10-11 retrorse serrations along posterior margin; serrations along both margins progressively larger toward spine tip. Pelvic-fin i,5, margin rounded. Adipose fin small, origin on vertical through end of anal-fin base. Anal fin iii,7; anal-fin pterygiophores in eight rod-like proximal radials and seven cartilaginous distal radials. Caudal fin deeply forked, lobes with pointed tips, $8+9$ principal rays, 5-8 upper procurrent, 5-6 lower procurrent rays. Pleural ribs 9 attached to consecutive vertebrae. Post-Weberian vertebrae $34(\mathrm{n}=2)$.

Color in alcohol. Dorsal surface of body, back and upper sides dark-brown sometimes with depigmented area around adipose fin. Lips and anterior nostril whitish. Head pigmentation pale, with posterior nuchal plates lighter. Lower sides and ventral surfaces whitish. Dorsal spine dark, subsequent rays darker only on its bases. Paired, anal and adipose fins unpigmented. Caudal-fin base with chromatophores becoming progressively more widely spaced, with hyaline lobes and tips. 


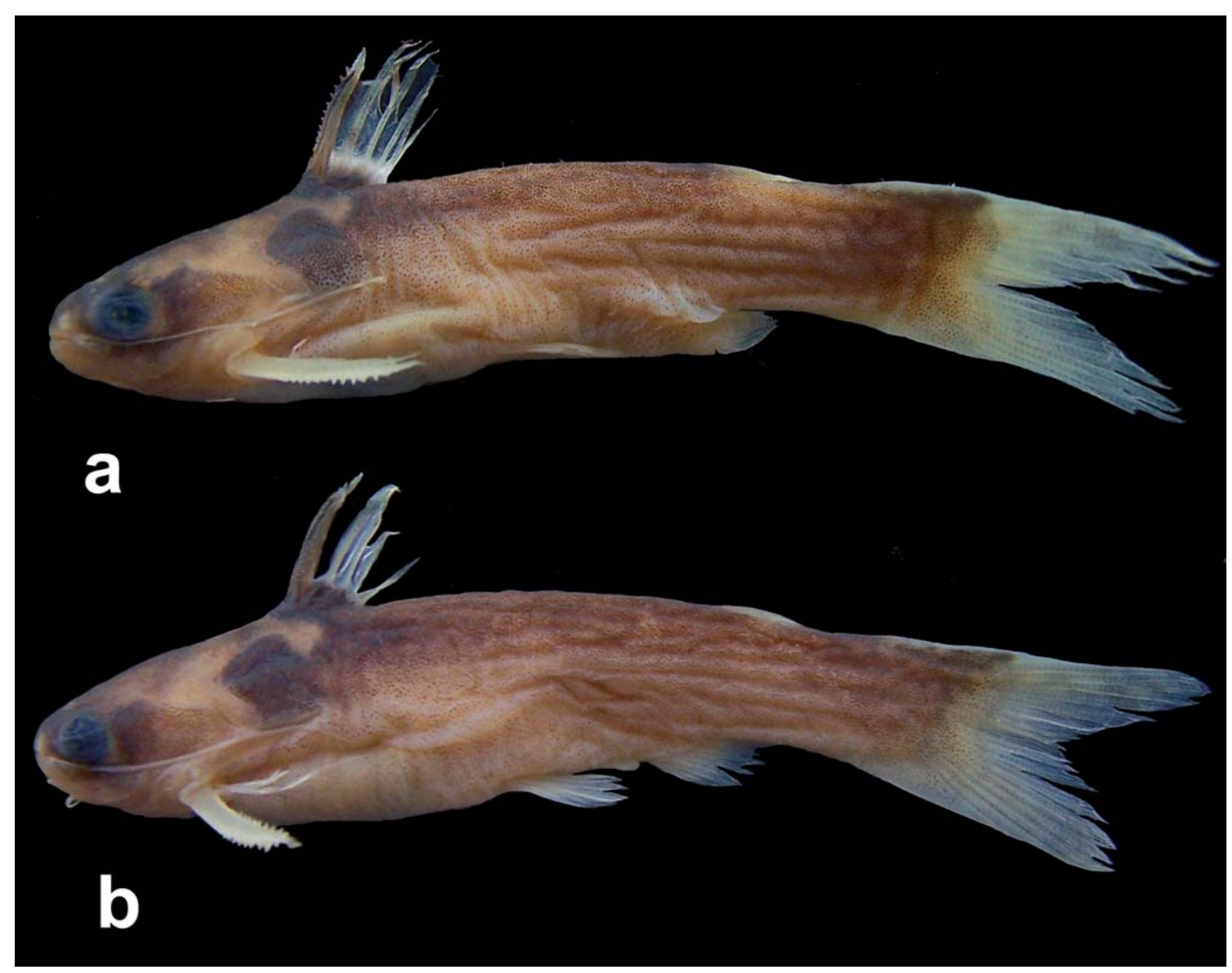

Fig. 30. Tatia meesi. (a) holotype, INHS 99772, male, $44.3 \mathrm{~mm}$ SL. (b) paratype, INHS 49549, female, 46.6 mm SL, Essequibo river, Guyana.

Sexual dimorphism. Based on examination of gonads, T. meesi attains sexual maturity above $39.5 \mathrm{~mm}$ SL. A genital papilla is not evident in females. The genital papilla of mature male is visible, with a short deferent duct. Adult male anal fin (Fig. 32 ) is strongly modified with a pointed tip. First unbranched anal-fin ray thickened. Second unbranched ray with a sharp tip curved towards the third unbranched ray, but not prolonged until the fin tip (Fig. 32, uii). Third unbranched ray is the longest one, forming a narrow fin tip, with distal segments gently curved (Fig. 32, uiii). First, second and third branched anal-fin rays are progressively shorter and curved towards the fin tip. Posterior branched rays normally developed; last ray not reduced (Fig. 32, b7). The caudal fin lobes have about same length in both adult males and females.

Distribution. Known only from type locality in the Essequibo basin, Guyana (Fig. 6).

Etymology. The specific name honors Dr. Gerloff F. Mees, for his significant contributions to our knowledge of the genus
Tatia, especially with regards to the species of the Guyana shield.

Remarks. The Waratuk cataract, the type locality of T. meesi, consists of rapidly flowing water over huge boulders. At the base of the cataract is a large pool and backwater area with a substrate of sand, gravel and rubble over bedrock give shelter to some catfish species, including the tiny $T$. meesi (L. Page, pers. comm.).

Among Tatia, subdivided fontanel apertures, with two openings separated to each other by orbitosphenoid suture is observed only in T. meesi. Dissection of alcoholic specimens confirmed the presence of an anterior and posterior fontanel. The orbitosphenoid is the place for origin of the facial mandibular muscle adductor arcus palatini. Tatia meesi has some features that are uncommon within the genus such as a tubular nasal bone and caudal-fin lobes of equal size in both males and females. It shares with $T$. gyrina a low number of canalicular infraorbitals and a low number of branchiostegal rays. It is distinct from $T$. intermedia, the only congener in- 
habiting the Essequibo basin, due to a cranial fontanel with two openings ( $v s$. single opening in T. intermedia); nasal tubular, rod-like, not sutured to mesethmoid ( $v s$. with lateral bony flanges, sutured to mesethmoid in T. intermedia); adult specimens small sized, less than $50 \mathrm{~mm}$ SL ( $v s$. large adult size, more than $50 \mathrm{~mm} \mathrm{SL}$ ).

The color pattern, consisting of small chromatophores concentrated mainly on dorsolateral part of body in T. meesi, resembles superficially the pattern in T. boemia. In T. meesi, however, the caudal fin is hyaline $v$ s. with small spots in T. boemia.

\section{Tatia neivai (Ihering, 1930)}

Fig. 33-35

Tatia intermedia. Miranda Ribeiro, 1918: 734 [Piquete \& Piracicaba, São Paulo]. Fowler, 1951: 470 [literature compilation]. Miranda Ribeiro, 1962: 10 [reference].

Glanidium neivai Ihering, 1930: 99, pl. 13, fig. 1 [type locality: Piracicaba river, Piracicaba, São Paulo]. Gosline, 1945: 11 [listing]. Miranda Ribeiro, 1962: 3 [reference].

Tatia neivai. Mees, 1974: 71-74, fig. 16 [notes and distribution]. Sands, 1984: 42 [listing]. Burgess, 1989: 242, pl. 108 [reference]. Soares-Porto, 1998: 333 [citation]. Britski et al., 1999: 113 [Pantanal Mato-Grossense]. Casatti et al.,

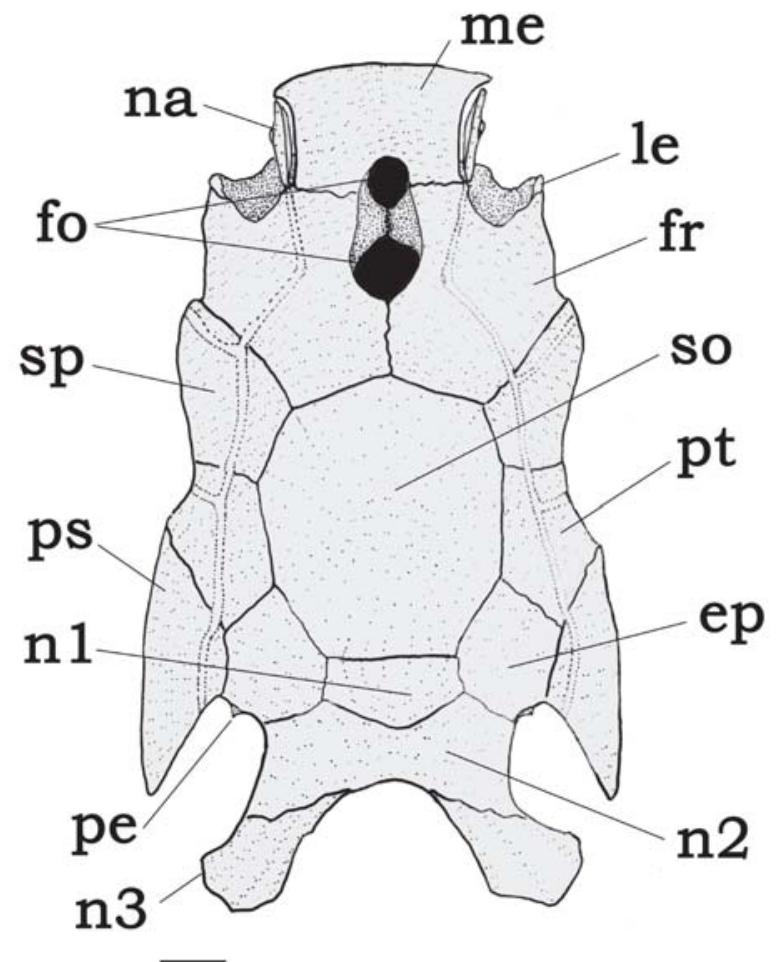

Fig. 31. Neurocranium of Tatia meesi, new species, INHS 49549, paratype, $43.3 \mathrm{~mm}$ SL. Dorsal view. Abbreviations: ep, epioccipital; fo, single cranial fontanel, fr, frontal; le, lateral ethmoid; me, mesethmoid; na, nasal; n1, first nuchal plate, n2; second nuchal plate; $\mathbf{n 3}$, third nuchal plate; pe, posterior epioccipital process; ps, posttemporal-supracleithrum; pt, pterotic; so, supraoccipital; sp, sphenotic. Scale bar $=1 \mathrm{~mm}$.
2001:5 [upper Paraná river]. Nakatani et al., 2001: 248 [larval development]. Ferraris, 2003:477 [check list]. Veríssimo et al., 2005: 7 [Manso river]. Ferraris, 2007: 77 [check list]. Tatia cf. aulopygia. Mees, 1988: 409 fig. 1 [Paraguay]. Burgess, 1989:242 [reference].

Diagnosis. Tatia neivai is distinguished from other species of Tatia by its unique color pattern with scattered small white spots over the sides of the body and the caudal fin with dark vertical bars. The species is also distinguished by the following combination of characters: third nuchal plate broad, with short lateral projection, and post-Weberian vertebrae alternatingly ribbed and unribbed. Additional features useful for distinguishing the species include: caudal-fin lobes of equal length in mature females, upper lobe more elongated in mature males; $31-33$ post-Weberian vertebrae.

Description. Measured adult specimens 48.1-82.1 mm SL; morphometric data presented in Table 11. Body slim, head slightly depressed dorso-ventrally. Head large, robust, dorsal profile of head elliptic, broader than long. Dorsal outline of trunk from dorsal-fin base to caudal peduncle gradually

Table 10. Morphometric data for Tatia meesi. $\mathrm{SD}=$ standard deviation.

\begin{tabular}{|c|c|c|c|c|c|}
\hline & $\begin{array}{c}\text { Holotype } \\
\text { INHS } 99772\end{array}$ & $\begin{array}{l}\text { Range } \\
(n=10)\end{array}$ & Mean & $\mathrm{SD}$ & $\mathrm{N}$ \\
\hline Standard length & 44.3 & $39.5-46.6$ & 43.6 & & 10 \\
\hline \multicolumn{6}{|c|}{ Percents of standard length } \\
\hline Body depth & 19.4 & $19.4-22.5$ & 20.7 & 1.01 & 10 \\
\hline Body width & 19.2 & $18.3-20.2$ & 19.2 & 0.58 & 10 \\
\hline Caudal peduncle depth & 12.0 & $10.4-12.3$ & 11.4 & 0.66 & 10 \\
\hline Caudal peduncle length & 28.0 & $24.5-28.1$ & 27.0 & 1.41 & 10 \\
\hline Predorsal length & 30.5 & $28.8-34.9$ & 31.7 & 1.87 & 10 \\
\hline Preanal length & 71.3 & $62.2-71.3$ & 65.1 & 3.08 & 10 \\
\hline Prepelvic length & 49.9 & $48.1-51.5$ & 49.7 & 1.12 & 10 \\
\hline Dorsal origin to pectoral origin & 24.4 & $22.3-25.5$ & 23.9 & 1.25 & 10 \\
\hline Dorsal origin to pelvic origin & 28.2 & $28.1-32.6$ & 30.4 & 1.69 & 10 \\
\hline Pectoral origin to pelvic origin & 30.0 & $30.0-35.4$ & 32.8 & 1.37 & 10 \\
\hline Prepectoral length & 19.9 & $18.4-22.1$ & 19.8 & 1.04 & 10 \\
\hline Dorsal-fin base length & 10.6 & $8.4-10.9$ & 9.8 & 0.87 & 10 \\
\hline Adipose-fin base length & 8.1 & $8.1-10.4$ & 9.1 & 0.84 & 10 \\
\hline Anal-fin base length & 4.7 & $4.7-10.5$ & 8.4 & 1.88 & 10 \\
\hline Dorsal-fin spine length & 19.0 & $14.0-19.0$ & 16.4 & 1.52 & 10 \\
\hline Pectoral-fin spine length & 25.3 & $20.2-25.3$ & 21.9 & 1.50 & 10 \\
\hline Postcleithral process lenght & 19.2 & $18.7-22.0$ & 20.0 & 1.01 & 10 \\
\hline First branched pelvic-fin ray & 13.8 & $11.4-14.5$ & 13.0 & 1.13 & 10 \\
\hline Longest anal fin ray & 8.4 & $7.4-12.6$ & 9.5 & 1.71 & 10 \\
\hline Maxillary barbel length & 36.1 & $32.2-39.6$ & 35.8 & 2.36 & 10 \\
\hline Outer mental barbel length & 9.3 & $7.1-10.5$ & 9.3 & 1.07 & 10 \\
\hline Mental barbel length & 4.5 & $4.3-5.8$ & 5.0 & 0.54 & 10 \\
\hline Head length & 24.6 & $23.0-27.4$ & 24.6 & 1.14 & 10 \\
\hline \multicolumn{6}{|c|}{ Percents of head length } \\
\hline Head width & 70.6 & $67.3-74.7$ & 71.0 & 2.44 & 10 \\
\hline Snout depth & 40.4 & $40.4-44.8$ & 42.7 & 1.81 & 10 \\
\hline Interorbital distance & 55.0 & $51.8-56.6$ & 54.7 & 1.51 & 10 \\
\hline Left internarial width & 23.9 & $21.7-26.1$ & 23.7 & 1.57 & 10 \\
\hline Anterior internarial distance & 40.4 & $36.9-40.4$ & 38.7 & 1.20 & 10 \\
\hline Posterior internarial distance & 38.5 & $36.9-40.6$ & 38.7 & 1.18 & 10 \\
\hline Snout length & 36.7 & $34.6-39.6$ & 37.4 & 1.96 & 10 \\
\hline Orbital diameter & 23.9 & $19.7-27.4$ & 23.9 & 1.87 & 10 \\
\hline Mouth width & 51.4 & $47.2-53.3$ & 49.5 & 1.54 & 10 \\
\hline
\end{tabular}


compressed posteriorly. Lateral profile of head from snout tip to above opercular margin slightly convex until pectoral-fin insertion. Ventral profile of head and abdomen flat. Ventral profile of body concave posterior to anal fin.

Head integument thin, cranial roof visible; well-developed adipose eye lid; eye latero-dorsally located in anterior portion of head; mouth terminal, upper lip extended posterolaterally as well-developed fleshy rictal fold; snout margin rounded; anterior nostril tubular, located on anterior border of snout; posterior nostril large, rounded, limited by small skin flap; transverse distance between anterior nostrils slightly larger than distance between posterior ones. Maxillary barbel moderate in size, extending to posterior tip of postcleithral process, sometimes longer; mental barbel arranged in arc along ventral surface of jaw, tips not reaching pectoral-fin base; inner mental barbel about $60.0-70.0 \%$ length of outer mentals. Postcleithral process well developed, almost reaching vertical through middle of dorsal fin. Caudal peduncle moderately deep, its depth about $13.6-14.8 \%$ SL.

Rostral border of cranium with mesethmoid as broad as long; premaxilla underneath with synchondral articulation; cranial fontanel narrow, elliptical, bounded by mesethmoid and frontal (Fig. 33); nasal ossified, with short medial flanges partially sutured to lateral margin of mesethmoid; autopalatine tubular, oriented obliquely to longitudinal axis of body; maxilla small, shorter than autopalatine; prevomer expanded anteriorly, with well developed arrow-shaped lateral processes; jaws of equal size; premaxilla and dentary with three to four rows of conical teeth. First nuchal plate short, somewhat elliptical; second nuchal plate laterally concave, partially in contact with supraoccipital in some specimens; third nuchal plate relatively straight, projected laterally. Epioccipital process small.

Suspensorium, hyoid arch, branchial skeleton and opercular bones as in generic description. Suprapreopercle present as a very short canal bone. Six branchiostegal rays articulated with hyoid arch: four with anterior ceratohyal and two with posterior ceratohyal; last one largest and expanded.

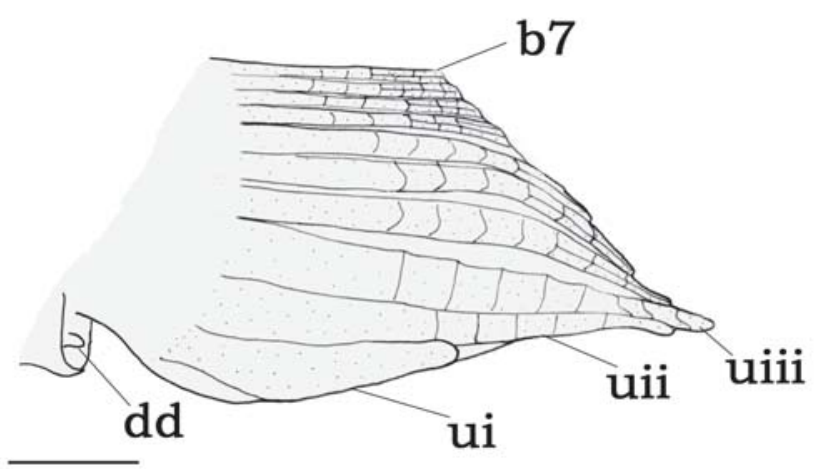

Fig. 32. Male modified anal fin of Tatia meesi, INHS 49549, paratype, $43.3 \mathrm{~mm}$ SL. Left side lateral view. Abbreviations: b7, branched seventh ray; dd, deferent duct; ui, unbranched first ray; uii, unbranched second ray; uiii, unbranched third ray. Scale bar $=1 \mathrm{~mm}$.
Five infraorbital bones in incomplete series. Infraorbital 1 broad, with short developed ventro-lateral process around anterior border of eye; remaining infraorbitals thin, reduced to canalicular portions. Infraorbital 2 smallest, close to infraorbital 1 , followed by non-ossified portion of canal below eye and by three posterior canal bones forming posterior orbital rim. Lateral line on body with ossified canal bones limited to head.

Dorsal fin I,4-5, rarely I,4 $(n=25)$; dorsal-fin spine with 1215 antrorse serrations along entire margin; posterior margin smooth. Pectoral fin I,4-5, rarely I,5 $(\mathrm{n}=25)$; pectoral-fin spine with 19-24 antrorse serrations along anterior margin, small serrations close to spine base; $13-17$ retrorse serrations along posterior margin; serrations along both margins progressively larger towards spine tip. Pelvic-fin i,5 ( $\mathrm{n}=25)$, margin rounded. Adipose fin short, origin on vertical through end of anal-fin base. Anal fin iii, 6-7, rarely iii, $6(\mathrm{n}=25)$; anal-fin pterygiophores in eight rod-like proximal radials and seven cartilaginous distal radials. Caudal fin forked, lobes with rounded tips, $8+9$ principal rays, 19-21 upper procurrent, 19-20 lower procurrent rays $(n=25)$. Seven or nine pleural ribs attached to consecutive vertebrae plus one attached to $9^{\text {th }}$ or $11^{\text {th }}$ vertebrae. The $8^{\text {th }}$ or $10^{\text {th }}$ vertebrae correspond to gap, with no ribs attached. Ribs progressively small anteroposterioly. Post-Weberian vertebrae $31-33(n=4)$.

Color in alcohol. Color pattern usually with scattered small white spots over lateral sides of body mainly distributed over ventrolateral parts. Dorsal spine usually with transverse bands; pectoral-fin spine not pigmented. Caudal fin with irregular dark vertical bars. Posterior nuchal plates somewhat pale. Lips and nostrils whitish. Ventral portion of head around chin light brown.

Color variation. Regional variation in coloration was observed regarding specimens from the upper Paraná river immediately above the Sete Quedas waterfalls (MHNG 2355.92). These specimens have a dark body coloration, with only a few white spots ventrally, and a caudal fin with vertical bars. Some specimens from the upper Paraguay river in the Pantanal of Mato Grosso are light brown over dorsal parts of the body, with scatteredspots along ventrolateral parts of body, and with a vertically barred caudal fin.

Sexual dimorphism. Based on examination of gonads, $T$. neivai attains sexual maturity above $48.1 \mathrm{~mm}$ SL. A genital papilla is not evident in females. The genital papilla of mature male is visible, with a short deferent duct. Male anal fin (Fig. 35 ) is modified with the three unbranched and first branched rays enlarged and thickened. First unbranched ray is nonsegmented, and immediately preceded by a tegumentary keel (Fig. 35, tk). The second unbranched ray is elongated, coalescing towards fin tip. The third unbranched and first branched rays are the longest, forming a short fin tip. The third unbranched ray has two antrorsely curved distal segments (Fig. 35, al). The first branched ray has four or five 
retrorsely curved distal segments (Fig. 35, rl).The posterior branched rays become progressively shorter, with the last ray not reduced (Fig. 35, b7).

Hemal spines 14-17 are interdigitating with the anal-fin pterygiophores. The hemal spines $15-17$ are thick in mature males, but undifferentiated in females. The male upper caudal-fin lobe is slightly elongate, about $15.0 \%$ longer than the lower lobe, whereas in mature females there are equal lobes.

Distribution. Tatia neivai occurs in the upper Paraguay river, in the Pantanal of Mato Grosso, Brazil, upper Paraná river, and upper Paraíba do Sul river (Fig. 6). It is recorded from several tributaries of the upper Paraná river, Brazil, such as the Grande river in Minas Gerais, the Tietê and Paranapanema rivers in São Paulo, and the Tibagi river in Paraná. In the upper Paraíba do Sul river the species was recorded from Piquete, São Paulo State. The single record from the São Francisco river is uncertain (MZUSP 3801) because the locality data are dubious.

Remarks. Tatia neivai was observed in semi-lotic environments. Some of these catfishes were found hidden within marginal vegetation or were captured inside crevices of submersed trunks (O. Shibatta pers. comm.).

Tatia neivai was described based on a single specimen from the Piracicaba river. The holotype is lost, but Ihering (1930: pl. 13) illustrated the specimen as having irregularly scratched color pattern on the sides of the body and the caudal fin with dark vertical bars. This color pattern distinguishes T. neivai from most Tatia species, except some $T$. aulopygia. Variation in coloration may occur among populations, but the caudal fin is always barred, and sometimes resembles that of $T$. aulopygia. In spite of this similarity, $T$. neivai and T. aulopygia can be distinguished on the basis of proportional measurements, the size of cranial fontanel (bounded by mesethmoid and frontal in T. neivai vs. restricted to frontal in T. aulopygia); the modified anal fin of adult males (distal margin continuous, without notch in T. neivai vs. notched in T. aulopygia) and the post-Weberian vertebrae (31-33 in T. neivai vs. 38-39 in T. aulopygia).

Material examined. 60 specimens (23.1-82.1mm SL). Brazil: Goiás: NUPELIA unnumbered, 1, (58.4 mm SL), Corumbá river, near Ipameri, Pires do Rio District. Mato Grosso do Sul: MZUSP 35882, 1 (26.6 mm SL), Piquiri river, Santo Antônio do Paraíso farm, Itiquira; MZUSP 36364, 2 (27.7-46.8 mm SL), Corixão, Capão Grande, Nhecolândia, Corumbá; MZUSP 42145, 2 (23.6-33.9 mm SL), lake about $25 \mathrm{Km}$ from Poconé, on road to Porto Cercado. Paraná: MZUEL 206, 1 (56.0 mm SL); MZUEL 207, 1 (53.7 mm SL); MZUEL 1098, 1 (63.5 mm SL), Tibagi river, município de Sertanópolis. Minas Gerais: MNRJ 28722, 2 (61.1-76.4 mm SL), Grande river, upstream from Porto Colombia dam. São Paulo: MZUSP 1993, 1 (62.1 mm SL), Piquete; MZUSP 2000, 1 (54.4 mm SL), Piracicaba river; MZUSP 35360, 1 (62.3 mm SL), Araguá river, Botucatu; MZUSP 42569, 2 (58.2 mm SL), Piracicaba river, Piracicaba; MZUSP 42570, 1 CS

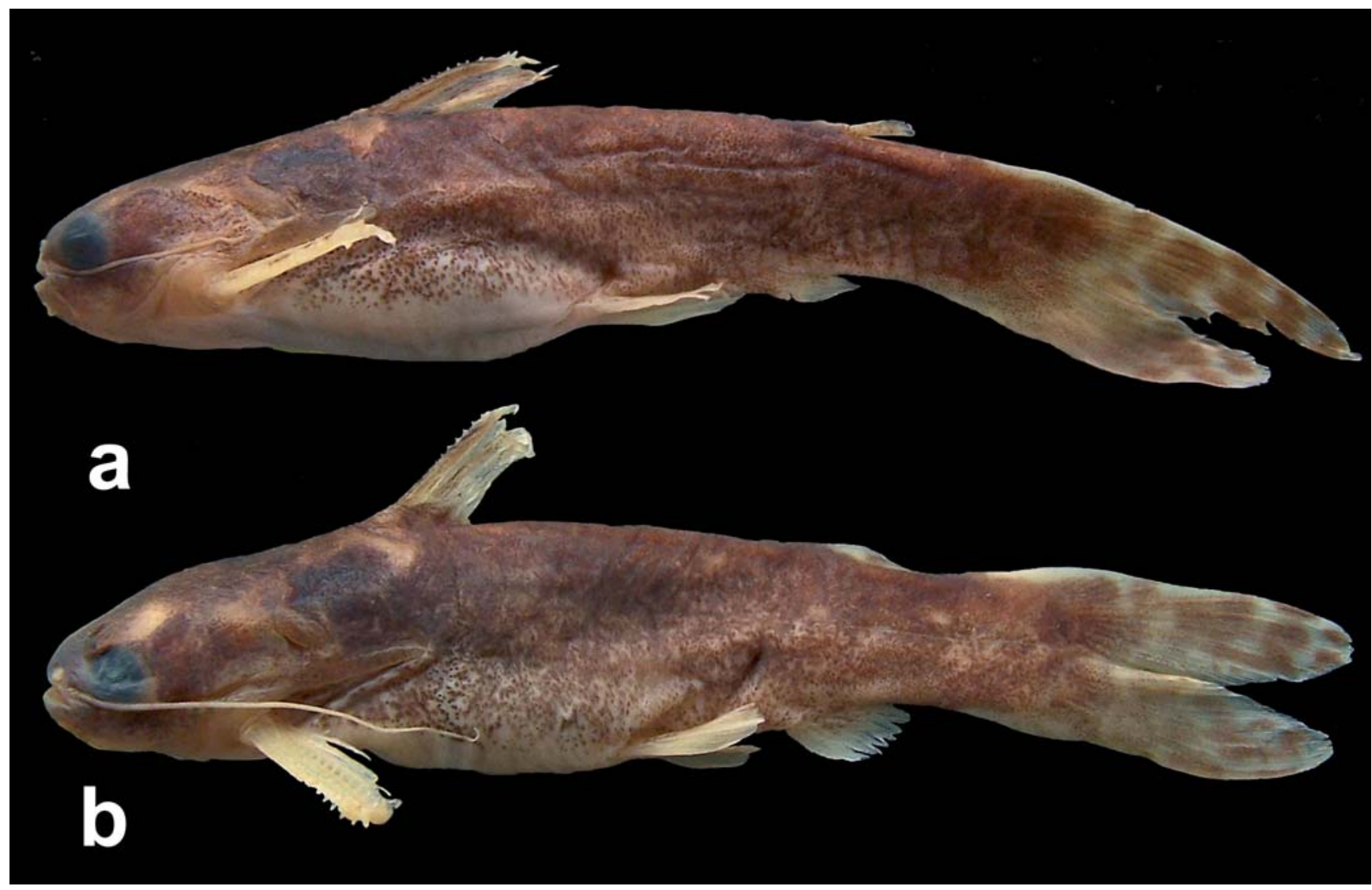

Fig. 33. Tatia neivai. (a) MHNG 2355.92, male, 51.6 mm SL. (b) MHNG 2355.92, female, 53.3 mm SL, Yuguyry stream, Paraguay. 
(60.5 mm SL), lake on Atibaia river, near Jaguariuna; MZUSP 45099, 1 (48.9 mm SL), Tietê river, Itápolis; MZUSP 46009, 1 (56.0 mm SL), Corumbataí river, Corumbataí; MZUSP 46855, 2 (23.1-41.0 mm SL), Pardo river, near Guaíra; MZUSP 47505, 7 (53.1-62.1 mm SL), ilha Solteira, Paraná river, Ilha Solteira dam. Paraguay: MHNG 2159.45, 1 (56.7 mm SL), Itapua: Tembey river. MHNG 2353.30, 1 (48.0 mm SL), salto Pirareta, La Cordillera. MHNG 2355.92, 12 (50.7-63.7 mm SL), Caaguazu: Yuguyry stream, about $17 \mathrm{Km}$ south of Yhu. MHNG 2430.19, 1 (R) (76.1 mm SL), lake on Iguazu river, upper Paraná. MHNG 2480.48, 1 (82.1 mm SL). MHNG 2480.49, 1 (43.6 mm SL), Canindeyú: Salto Guaira, Itaipu lake. MHNG 2537.73, 8, $1 \mathrm{CS},(37.2-46.6 \mathrm{~mm} \mathrm{SL})$, Tagatija-mi river, about $30 \mathrm{Km}$ east from Puerto Max; UMMZ 206602, 3 (29.6-30.4 mm SL), Aguaray river, San Pedro; USNM 249826, 1 (54.5 mm SL), Canindeyú: Carapa river, above waterfalls, old road from Stroessner to Guaira; ZMA 116.801, 1 (R) (66.2 mm SL), Itapua: Tembey river, $4 \mathrm{Km}$ above cataracts.

\section{Tatia nigra, new species}

Fig. 36-39

Holotype. INPA 12291 (116.8 mm SL), Brazil, Amazonas: Uatumã river, approximate coordenates $02^{\circ} 14^{\prime} 35^{\prime}$ 'S 58 $48^{\circ} 58^{\prime \prime}$, Oct 1983 , Ichthyology INPA team.

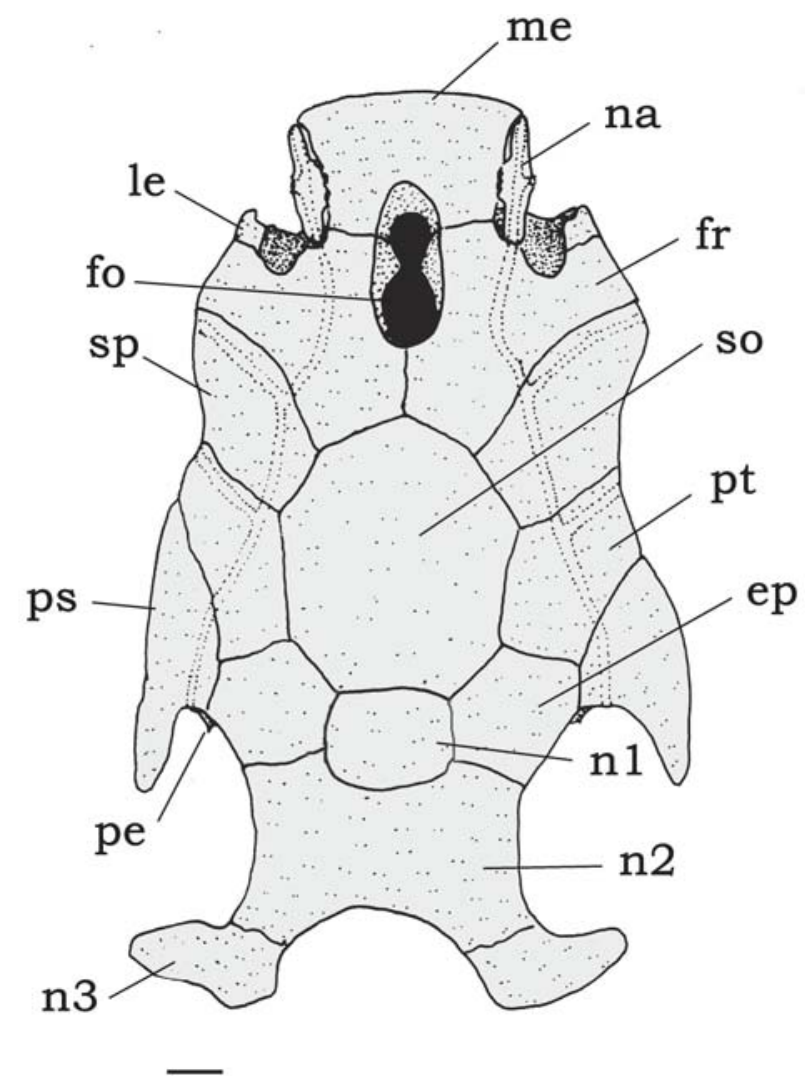

Fig. 34. Neurocranium of Tatia neivai, MZUSP 42570, 60.5 $\mathrm{mm}$ SL. Dorsal view. Abbreviations: ep, epioccipital; fo, single cranial fontanel, fr, frontal; le, lateral ethmoid; me, mesethmoid; na, nasal; n1, first nuchal plate, $\mathbf{n 2}$; second nuchal plate; $\mathbf{n}$, third nuchal plate; pe, posterior epioccipital process; ps, posttemporal-supracleithrum; pt, pterotic; so, supraoccipital; sp, sphenotic. Scale bar $=1 \mathrm{~mm}$.
Paratypes. Brazil, Amazonas: INPA 25501, 1 (107.3 mm SL), collected with the holotype; INPA 11073, 1 (93.7 mm SL); INPA 11075, 1 (113.5 mm SL); INPA 11081, 6 (86.6-107.8 mm SL); MNRJ 32024, 1 plus1 CS (97.0-98.2 mm SL), Uatumã river, Samaúma lake, Presidente Figueiredo; INPA 12296, 1 (72.0 mm SL) Uatumã river, igarapé Miriti. Pará: MNRJ 12358, 3 (70.0-82.3 mm SL) Trombetas river, Porto Trombetas.

Diagnosis. Tatia nigra is uniquely distinguished from congeners by having dark brown body color (Fig. 36) and short postcleithral process about $60.0 \%$ HL ( $v s$. more than $80.0 \%$ $\mathrm{HL}$ in other Tatia). Additional features useful for distinguishing T. nigra include: postcleithral spine not reaching vertical through origin of dorsal fin; nasal with well developed medial flanges; 32 vertebrae.

Description. Measured specimens 70.0-116.8 mm SL; morphometric data presented in Table 12. Body deep, head depressed dorso-ventrally. Outline of head in dorsal view almost rectangular, slightly broader than long. Trunk from dorsal-fin base to caudal peduncle becoming gradually compressed laterally. Lateral profile of head from snout tip to opercular margin convex until pectoral-fin insertion. Ventral profile of head and abdomen slightly convex. Ventral profile of body concave behind anal-fin origin.

Head integument thin, cranial roof visible; well-developed adipose eye lid; eye latero-dorsally located in anterior portion of head; mouth terminal, upper lip extended posterolaterally as a well-developed fleshy rictal fold; anterior nostril tubular, located on anterior border of snout; posterior nostril large, rounded, limited by small skin flap; transverse distance between anterior nostrils larger than distance between posterior ones. Maxillary barbel of moderate size, extending well beyond posterior tip of postcleithral process, reaching vertical line tangent to origin of dorsal fin; mental barbel short, tips not reaching pectoral-fin base, arranged in arc along ventral surface of jaw; inner mental barbel about 54.0-65.0\% length of outer mentals. Postcleithral process short, almost reaching vertical through middle nuchal plates. Caudal peduncle deep, depth about $14.4-17.0 \%$ SL.

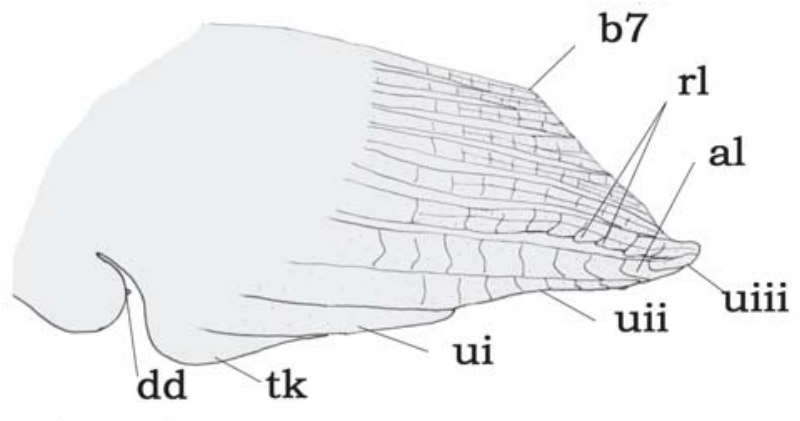

Fig. 35. Male modified anal fin of Tatia neivai, MZUEL 206, $56.0 \mathrm{~mm}$ SL. Left side lateral view. Abbreviations: ac, antrorsely curved denticulation; $\mathbf{b} 7$, branched seventh ray; $\mathbf{d d}$, deferent duct; rc, retrorsely curved denticulation; tk, tegumentary keel; ui, unbranched first ray; uii, unbranched second ray; uiii, unbranched third ray. Scale bar $=1.0 \mathrm{~mm}$. 
Cranium with mesethmoid as long as broad; premaxilla underneath with synchondral articulation; elliptical narrow concavity for cranial fontanel, opening bounded by mesethmoid and frontal (Fig. 37); nasal ossified, with wide medial flanges partially sutured to lateral margin of mesethmoid; autopalatine tubular, oriented obliquely to longitudinal axis of body; maxilla about same size of autopalatine; prevomer expanded anteriorly with well developed arrowshaped lateral processes; jaws of equal size; premaxilla and dentary with three to four rows of conical teeth. First nuchal plate somewhat pentagonal; second nuchal plate concave along lateral margins; third nuchal plate curved, projected laterally, with small tip. Epioccipital process very small.

Suspensorium, hyoid arch, branchial skeleton and opercular bones as in generic description. Suprapreopercle present as short canal bone. Six branchiostegal rays articulated with hyoid arch: four with anterior ceratohyal and two with posterior ceratohyal; last two flattened and expanded. Basibranchial 2 forming osseous rod with a broad cartilaginous anterior tip, separated from shorter basibranchial 3.

Five infraorbital bones in incomplete series. Infraorbital 1 broad, with short ventro-lateral process; remaining infraorbitals thin, reduced to canalicular portions. Infraorbital

Table 11. Morphometric data for Tatia neivai. $\mathrm{SD}=$ standard deviation.

\begin{tabular}{|c|c|c|c|c|}
\hline & Range & Mean & $\mathrm{SD}$ & $\mathrm{N}$ \\
\hline Standard length & $48.8-82.1$ & 58.4 & & 9 \\
\hline \multicolumn{5}{|c|}{ Percents of standard length } \\
\hline Body depth & $18.1-24.6$ & 20.3 & 1.98 & 9 \\
\hline Body width & $17.5-21.8$ & 19.8 & 1.00 & 9 \\
\hline Caudal peduncle depth & $13.6-14.8$ & 14.1 & 1.10 & 9 \\
\hline Caudal peduncle length & $20.9-28.1$ & 24.7 & 1.83 & 6 \\
\hline Predorsal length & $26.8-36.4$ & 32.1 & 1.68 & 9 \\
\hline Preanal length & $64.9-74.8$ & 69.3 & 2.84 & 9 \\
\hline Prepelvic length & $50.0-56.5$ & 52.5 & 1.80 & 9 \\
\hline Dorsal origin to pectoral origin & $19.7-26.6$ & 23.0 & 1.45 & 9 \\
\hline Dorsal origin to pelvic origin & $27.3-34.3$ & 31.1 & 1.97 & 9 \\
\hline Pectoral origin to pelvic origin & $30.6-38.2$ & 35.0 & 1.97 & 9 \\
\hline Prepectoral length & $16.1-23.7$ & 20.3 & 1.73 & 9 \\
\hline Dorsal-fin base length & $8.0-11.8$ & 10.2 & 0.93 & 9 \\
\hline Adipose-fin base length & $7.4-13.8$ & 11.0 & 1.80 & 9 \\
\hline Anal-fin base length & $2.9-12.3$ & 7.0 & 2.73 & 9 \\
\hline Dorsal-fin spine length & $13.4-21.2$ & 17.8 & 1.99 & 8 \\
\hline Pectoral-fin spine length & $22.0-27.1$ & 23.6 & 1.66 & 9 \\
\hline Postcleithral process lenght & $13.2-22.1$ & 19.7 & 1.99 & 9 \\
\hline First branched pelvic-fin ray & $8.6-15.1$ & 12.8 & 1.30 & 9 \\
\hline Longest anal fin ray & $5.7-10.3$ & 8.3 & 1.31 & 9 \\
\hline Maxillary barbel length & $30.0-34.9$ & 32.1 & 1.94 & 9 \\
\hline Outer mental barbel length & $6.9-11.1$ & 8.9 & 1.26 & 9 \\
\hline Mental barbel length & $4.8-11.4$ & 6.3 & 1.42 & 9 \\
\hline Head length & $21.3-26.7$ & 23.4 & 1.42 & 9 \\
\hline \multicolumn{5}{|c|}{ Percents of head length } \\
\hline Head width & $70.8-76.9$ & 74.5 & 1.99 & 9 \\
\hline Snout depth & $52.1-57.7$ & 54.8 & 1.96 & 6 \\
\hline Interorbital distance & $53.0-58.7$ & 55.7 & 1.88 & 9 \\
\hline Left internarial width & $20.8-28.5$ & 24.3 & 1.94 & 6 \\
\hline Anterior internarial distance & $34.1-39.6$ & 37.4 & 1.78 & 6 \\
\hline Posterior internarial distance & $33.5-39.7$ & 36.7 & 1.98 & 9 \\
\hline Snout length & $33.0-38.8$ & 37.4 & 1.98 & 9 \\
\hline Orbital diameter & $20.0-24.2$ & 22.0 & 1.84 & 9 \\
\hline Mouth width & $47.9-52.9$ & 50.2 & 1.80 & 9 \\
\hline
\end{tabular}

2 smallest, close to infraorbital 1; infraorbital 3 elongate, followed by short non-ossified portion of canal. Posterior three canal bones forming posterior orbital rim. Lateral line on body with ossified canal bones only close to head.

Dorsal fin I,5 ( $\mathrm{n}=12)$; dorsal-fin spine with 19-22 antrorse serrations along entire anterior margin; posterior margin smooth. Pectoral fin I,5 ( $n=12)$; pectoral-fin spine with 28-31 antrorse serrations along anterior margin; 19-21 retrorse serrations along posterior margin; serrations along both margins progressively larger towards spine tip. Pelvic-fin i,5 $(n=12)$, margin rounded. Adipose fin small, origin on vertical through end of anal-fin base. Anal fin iii, $7(n=12)$; anal-fin pterygiophores in eight rod-like proximal radials and seven cartilaginous distal radials. Caudal fin forked, lobes with rounded tips, upper lobe slightly elongated in comparison to lower lobe, $8+9$ principal rays, 17-19 upper procurrent, 17-20 lower procurrent rays $(n=12)$. Pleural ribs 10 attached to consecutive vertebrae. Post-Weberian vertebrae $32(n=1)$.

Color in alcohol. Tatia nigra dark colored in large adult specimens. Dorsal mid-line and dorsolateral parts of body dark brown, as well as dorsal surface of head, nuchal shield, dorsal fin and adipose fin (Fig. 36). Body progressively paler towards ventral parts. Ventral portion of head around chin, lips and anterior nostrils light brown. Belly whitish to origin of pelvic fin. Pectoral, pelvic and anal fins light brown. Caudal fin dark brown.

Sexual dimorphism. Tatia nigra attains sexual maturity above $80.0 \mathrm{~mm}$ SL. The mature females have a small intumescent genital papilla. Male genital papilla is formed by a thick skin flap around a slender emergent deferent duct. Male modified anal fin (Fig. 38) has three unbranched and first branched rays enlarged and thickened. The first unbranched anal-fin ray is immediately preceded by a tegumentary keel (Fig. 38, tk). The second unbranched ray has an intermediate size between the neighboring first and third rays. Third unbranched is the longest ray, slightly curved towards fin tip; bearing smaller antrorsely curved distal segments (Fig. 38, ac). First branched ray is slightly curved towards the fin tip. First and second branched rays have retrorsely curved distal segments (Fig. 38, rc). Posterior branched rays are progressively shorter; with the last ray not reduced (Fig. 38, b7). Caudal-fin lobes of both analyzed mature females and males have the upper lobe elongated.

Six mature males of $T$. nigra with a modified anal fin were examined. In two of these males the modified anal fin is laterally curved and spoon shaped (Fig. 39), suggesting reproductive modification for internal inseminating.

Distribution. Known from the central Amazon, in the Uatumã and Trombetas river drainages, northern tributaries of the Amazon river (Fig. 6).

Etymology. The specific name nigra, is a Latin reference to the dark color pattern of this species. 


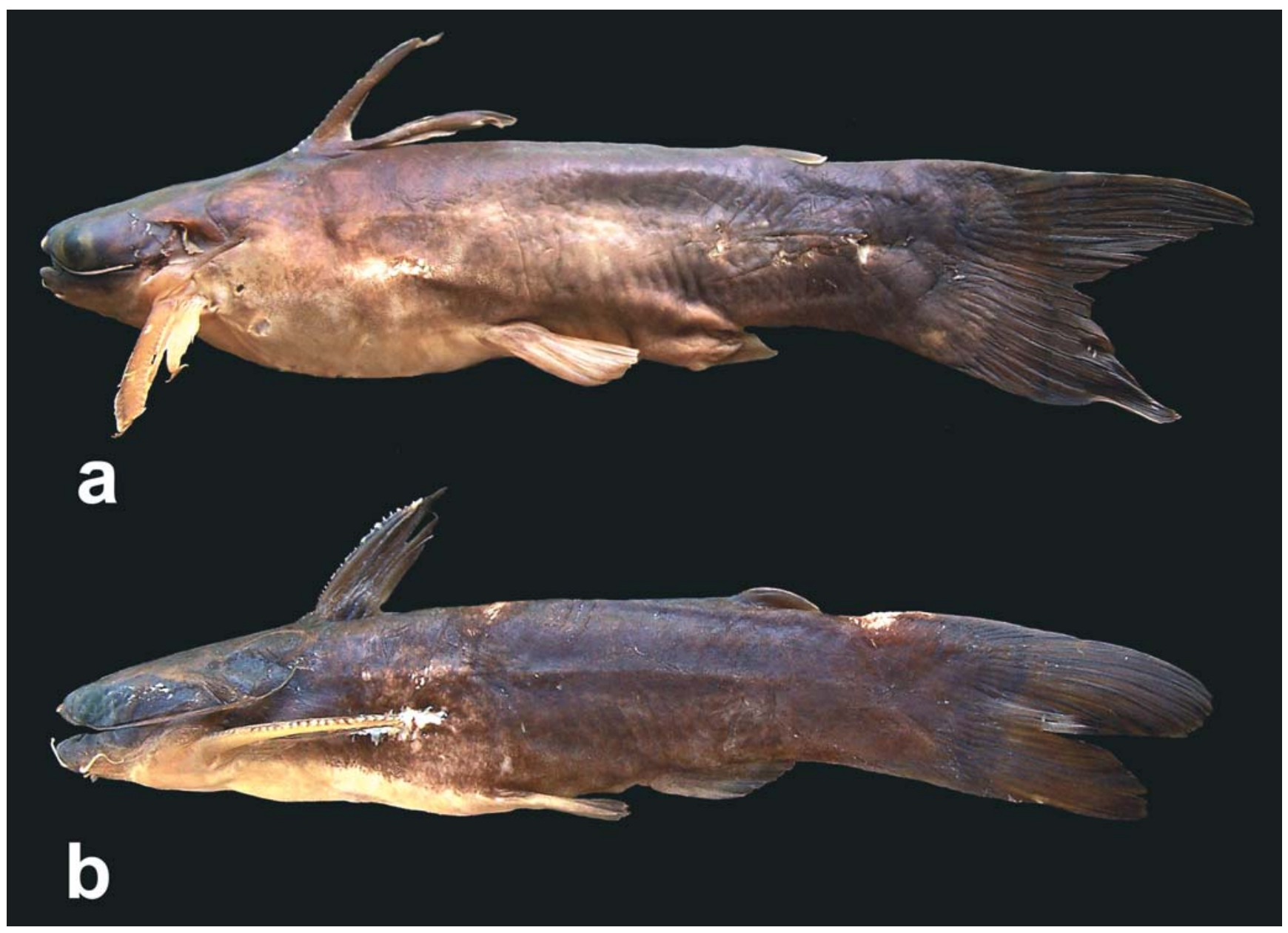

Fig. 36. Tatia nigra. (a) holotype, INPA 12291, male, $116.8 \mathrm{~mm}$ SL. (b) paratype, INPA 25501, female, $107.3 \mathrm{~mm}$ SL, Uatumã river, Amazonas State, Brazil.

Remarks. Tatia nigra has well-developed lateral ornamented medial flanges of bone on the nasal, but not as large as the flanges observed in T. aulopygia. The expanded nasal with medial flanges partially sutured to mesethmoid was recognized as a derived feature for the genus (Soares-Porto, 1998), and was also observed in T. aulopygia, T. boemia, T. dunni, T. neivai, T. strigata, and adult specimens of T. intermedia.

Female genital papilla in T. nigra is not a common condition within the genus. The only other Tatia with female genital papilla is T. gyrina. The intumescent female genital papilla may represent a transitory condition in species of Tatia, and perhaps is observed in specimens only close to reproductive phase. The elongated upper caudal-fin lobe in both mature females and males is rare within the genus and may be also associated to the reproductive phase.

Tatia nigra occurs in sympatry with T. brunnea in the Trombetas river, at lago do Batata, but not syntopically. The specimens of $T$. nigra were captured in the lake, while the $T$. brunnea was recorded from the igarapé Saracazinho, a tributary of the Batata lake.

\section{Tatia strigata Soares-Porto, 1995}

Figs. 40-42

Tatia cf. brunnea. Burgess, 1989: 242, pl. 113. [tropical South America].

Tatia strigata Soares-Porto, 1995: 202, fig. 1. [type locality: igarapé Limãozinho, Maués, Amazonas, Brazil]. Burgess \& Finley, 1996:166 [reference]. Soares-Porto, 1998: 333 [citation]. Ferraris, 2003:477 [checklist]. Lasso et al., 2005: 139 [Alto Orinoco, Orinoco]. Ferraris, 2007: 78 [checklist].

Diagnosis. Tatia strigata is the only species of the genus with a completely striped color pattern, bearing whitish elongate longitudinal irregular stripes along lateral sides of body. A unique arrangement of adult male modified anal fin is present, with the second unbranched anal-fin ray with anterior enlarged segments and a notch formed by the reduction of the second and third branched rays (Soares-Porto, 1995). Tatia strigata is also distinguished from all congeners by a combination of characteristics: four branched pectoral-fin rays; 7 ribs; 29-30 vertebrae; and mature males with upper caudal-fin lobe slightly elongated, same length in females. 
Table 12. Morphometric data for Tatia nigra $. \mathrm{SD}=$ standard deviation.

\begin{tabular}{|c|c|c|c|c|c|}
\hline & $\begin{array}{c}\text { Holotype } \\
\text { INPA } 12291\end{array}$ & Range & Mean & $\mathrm{SD}$ & $\mathrm{N}$ \\
\hline Standard length & 116.8 & $70.0-116.8$ & 101.6 & & 12 \\
\hline \multicolumn{6}{|c|}{ Percents of standard length } \\
\hline Body depth & 19.9 & $17.0-21.9$ & 19.5 & 1.47 & 12 \\
\hline Body width & 18.7 & $18.7-21.6$ & 19.6 & 0.81 & 12 \\
\hline Caudal peduncle depth & 15.4 & $14.4-17.0$ & 15.8 & 0.77 & 12 \\
\hline Caudal peduncle length & 28.6 & $22.2-28.6$ & 26.4 & 1.99 & 12 \\
\hline Predorsal length & 30.1 & $27.4-31.0$ & 29.9 & 0.94 & 12 \\
\hline Preanal length & 68.6 & $64.0-75.4$ & 68.1 & 3.30 & 12 \\
\hline Prepelvic length & 47.5 & $47.3-51.9$ & 49.5 & 1.47 & 12 \\
\hline Dorsal origin to pectoral origin & 21.0 & $18.5-23.3$ & 21.0 & 1.36 & 12 \\
\hline Dorsal origin to pelvic origin & 27.4 & $27.2-32.4$ & 29.9 & 1.83 & 12 \\
\hline Pectoral origin to pelvic origin & 33.1 & $30.7-37.3$ & 32.7 & 1.75 & 12 \\
\hline Prepectoral length & 17.8 & $17.8-22.1$ & 19.4 & 1.26 & 12 \\
\hline Dorsal-fin base length & 11.1 & $8.6-11.4$ & 9.9 & 0.80 & 12 \\
\hline Adipose-fin base length & 10.4 & $10.3-12.5$ & 11.0 & 0.68 & 12 \\
\hline Anal-fin base length & 4.2 & $3.0-11.9$ & 7.9 & 3.50 & 12 \\
\hline Dorsal-fin spine length & 19.7 & $16.3-22.0$ & 19.7 & 1.54 & 9 \\
\hline Pectoral-fin spine length & 20.5 & $20.3-24.6$ & 22.7 & 1.42 & 9 \\
\hline Postcleithral process lenght & 12.3 & $12.0-14.4$ & 13.1 & 0.81 & 12 \\
\hline First branched pelvic-fin ray & 13.8 & $11.8-15.1$ & 13.6 & 1.19 & 12 \\
\hline Longest anal fin ray & 8.3 & $4.7-10.7$ & 8.8 & 1.83 & 12 \\
\hline Maxillary barbel length & 27.9 & 25.6-30.9 & 27.8 & 1.91 & 12 \\
\hline Outer mental barbel length & 8.4 & $6.5-10.1$ & 8.1 & 1.09 & 12 \\
\hline Mental barbel length & 4.3 & $3.6-5.8$ & 4.8 & 0.65 & 12 \\
\hline Head length & 19.2 & $19.2-22.9$ & 21.3 & 1.08 & 12 \\
\hline \multicolumn{6}{|c|}{ Percents of head length } \\
\hline Head width & 82.1 & $77.5-82.2$ & 80.0 & 1.97 & 12 \\
\hline Snout depth & 49.1 & $47.0-53.7$ & 48.8 & 1.99 & 12 \\
\hline Interorbital distance & 66.5 & $61.3-66.7$ & 63.5 & 1.99 & 12 \\
\hline Left internarial width & 26.3 & $22.4-26.5$ & 24.7 & 1.53 & 12 \\
\hline Anterior internarial distance & 44.6 & $39.8-44.6$ & 42.7 & 1.98 & 12 \\
\hline Posterior internarial distance & 42.4 & $34.6-42.4$ & 39.0 & 1.91 & 12 \\
\hline Snout length & 40.6 & $38.5-43.1$ & 40.6 & 1.95 & 12 \\
\hline Orbital diameter & 24.1 & $23.0-27.8$ & 25.8 & 1.92 & 12 \\
\hline Mouth width & 53.6 & $48.5-53.6$ & 51.2 & 1.96 & 12 \\
\hline
\end{tabular}

Description. Measured specimens 36.5-55.0 mm SL; morphometric data presented in Table 13. Body slim, head slightly depressed dorso-ventrally. Head large, robust, outline of head in dorsal view somewhat elliptic, broader than long. Trunk from dorsal-fin base to caudal peduncle gradually compressed. Lateral profile of head from snout tip to opercular margin slightly convex until pectoral-fin insertion. Ventral profile of head and abdomen flat. Ventral profile of body gently curved, concave behind anal-fin origin. Head integument thin, cranial roof visible; well-developed adipose eye lid; eye latero-dorsally located in anterior portion of head; mouth terminal, upper lip extended postero-laterally as well-developed fleshy rictal fold; anterior nostril tubular, located on anterior border of snout; posterior nostril large, rounded, limited by small skin flap; transverse distance between anterior nostrils larger than distance between posterior ones. Maxillary barbel short, extending close to posterior tip of postcleithral process, sometimes shorter; mental barbel short, tips not reaching pectoralfin base, arranged in arc along ventral surface of jaw; inner mental barbel about 50.0-60.0\% length of outer mentals. Postcleithral process almost reaching vertical through origin of dorsal fin. Caudal peduncle deep, depth about 13.6-14.5\% SL.

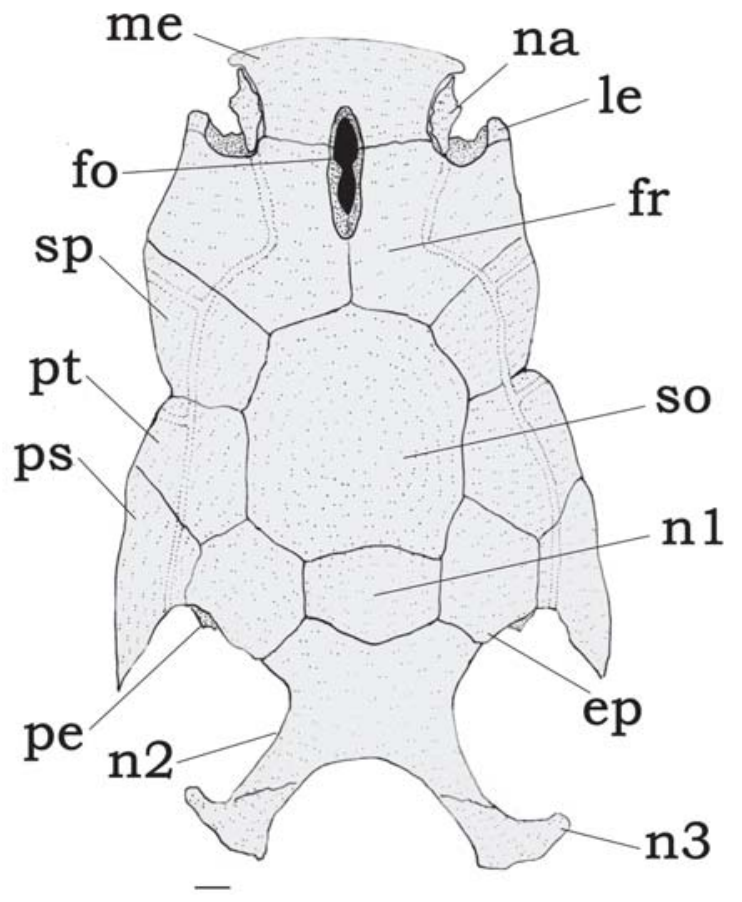

Fig. 37. Neurocranium of Tatia nigra, MNRJ 32024, $97.0 \mathrm{~mm}$ SL. Dorsal view. Abbreviations: ep, epioccipital; fo, single cranial fontanel, fr, frontal; le, lateral ethmoid; me, mesethmoid; $\mathbf{n a}$, nasal; n1, first nuchal plate, $\mathbf{n} 2$; second nuchal plate; n3, third nuchal plate; pe, posterior epioccipital process; ps, posttemporal-supracleithrum; pt, pterotic; so, supraoccipital; sp, sphenotic. Scale bar $=1 \mathrm{~mm}$.

Rostral border of cranium with mesethmoid as large as long; premaxilla underneath with synchondral articulation; large elliptical cranial fontanel bounded by mesethmoid and frontal (Fig. 41); nasal ossified with medial flanges partially sutured to lateral margin of mesethmoid; autopalatine tubular, oriented obliquely to longitudinal axis of body; maxilla about the same size as autopalatine; prevomer expanded anteriorly with well developed arrow-shaped lateral processes; jaws of equal size; premaxilla and dentary with three rows of conical teeth. First nuchal plate somewhat pentagonal; second nuchal plate concave along lateral margins; third nuchal plate curved, projected laterally. Epioccipital process very small.

Suspensorium, hyoid arch, branchial skeleton and opercular bones as in generic description. Suprapreopercle present as short canal bone. Six branchiostegal rays articulated with hyoid arch: four with anterior ceratohyal and two with posterior ceratohyal; last one flattened.

Four infraorbital bones in incomplete series. Infraorbital 1 broad, with short ventro-lateral process; remaining infraorbitals thin, reduced to canalicular portions. Infraorbital 2 smallest, close to infraorbital 1, followed by non-ossified portion of canal below eye and by two posterior canal bones much close to sphenotic, forming posterior orbital rim. Lateral line on body with ossified canal bones limited to head.

Dorsal fin I,4-5 ( $\mathrm{n}=10)$; dorsal-fin spine with 15-20 antrorse 


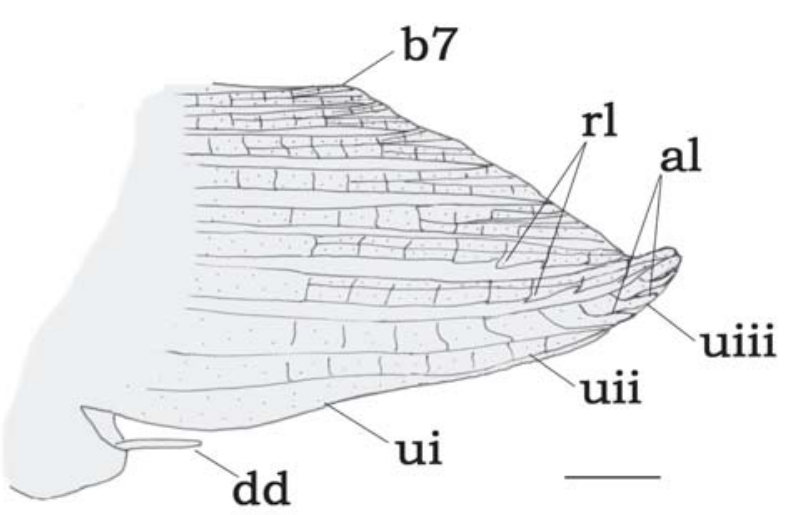

Fig. 38. Male modified anal fin of Tatia nigra, MNRJ 32024 , $97.0 \mathrm{~mm}$ SL. Left side lateral view. Abbreviations: al, antrorsely curved distal segment; $\mathbf{b} 7$, branched seventh ray; dd, deferent duct; rl, retrorsely curved distal segment ; ui, unbranched first ray; uii, unbranched second ray; uiii, unbranched third ray. Scale bar $=1.0 \mathrm{~mm}$.

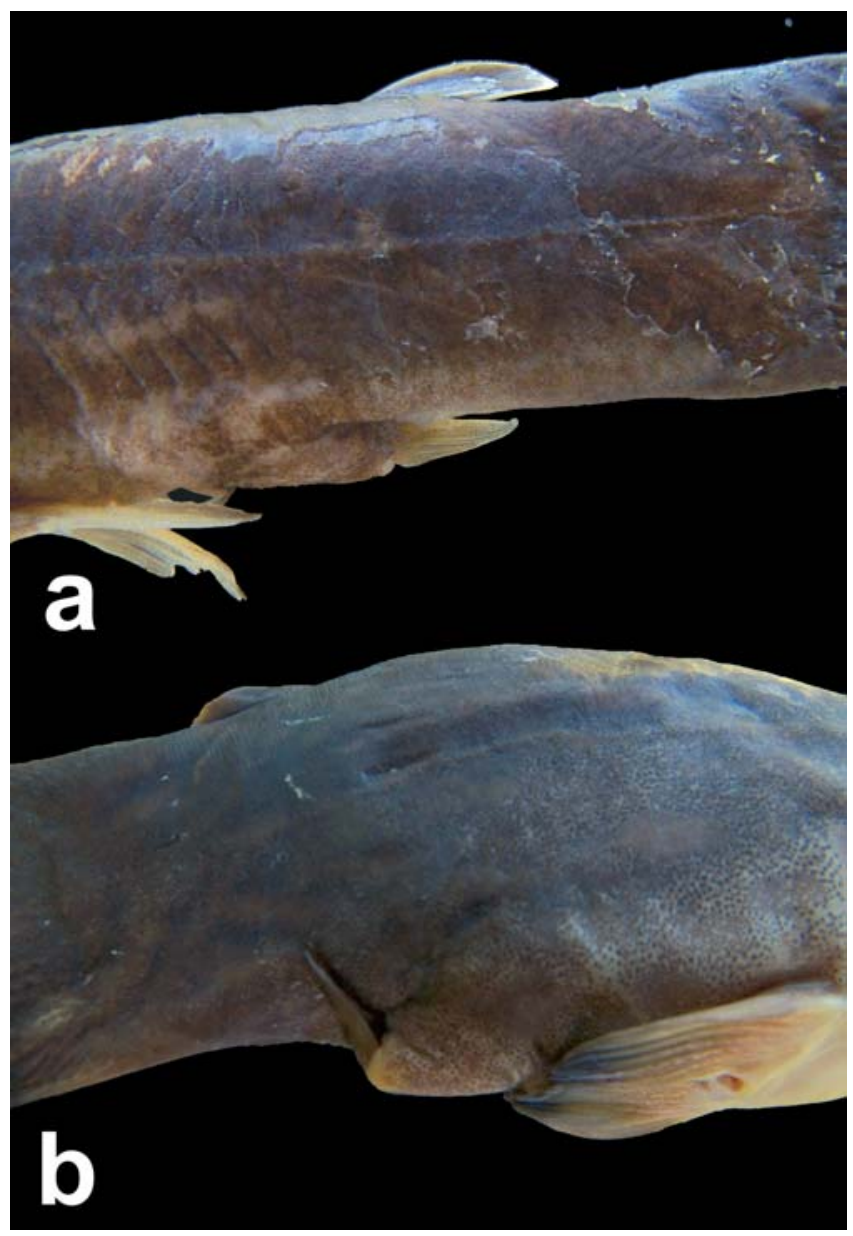

Fig. 39. Detail of male modified anal fin in Tatia nigra. (a) INPA 11081, male, $107.8 \mathrm{~mm} \mathrm{SL}$, anal fin parallel to body. (b) INPA 11081, male, $105.2 \mathrm{~mm} \mathrm{SL}$, anal fin spoon shaped and laterally curved. serrations along entire anterior margin; posterior margin smooth. Pectoral fin I,4 $(n=10)$, pectoral-fin spine with 17-21 antrorse serrations along anterior margin; $13-15$ retrorse serrations along posterior margin; serrations along both margins progressively larger towards spine tip. Pelvic-fin i,5 $(\mathrm{n}=10)$; margin rounded. Adipose fin small, origin on vertical through end of anal-fin base. Anal fin iii, 6-7 ( $\mathrm{n}=10)$; anal-fin pterygiophores in eight rod-like proximal radials and seven cartilaginous distal radials. Caudal fin forked, lobes with rounded tips, $8+9$ principal rays, 7-19 upper procurrent, 7-17 lower procurrent rays $(\mathrm{n}=10)$. Pleural ribs 7 attached to consecutive vertebrae. Post-Weberian vertebrae 29-30 $(n=3)$.

Color in alcohol. Dorsal surface, dorsal mid-line and lateral parts of body striated with light narrow longitudinal stripes. Dorsal surface of head and nuchal shield dark brown. Lips and anterior nostrils whitish. Ventral parts of head around chin whitish. Paired fins and anal fin hyaline. Adipose fin with dark base and hyaline tip. Caudal fin with dark brown rays and light brown membranes. Burgess (1989: pl. 113) illustrates live aquarium specimen.

Sexual dimorphism. A single adult male with modified anal fin was examined (MCZ 78092). Only young females are available, and genital papilla is not observed. A genital papilla is visible in the single mature male, with a thick skin flap around deferent duct. The anal fin of mature male (Fig. 42) is strongly modified, with three unbranched and the first two branched rays enlarged and thickened. The first unbranched ray has a rough anterior border and a curved tip (Fig. 42, ui). The second unbranched ray has the median segments enlarged anteriorly, projecting over the anterior ray (Fig. 42, uii); few segments are retrorsely curved (Fig. 42, rc). The third unbranched ray is the longest, forming a short tip (Fig. 42, uiii). The first and second branched anal-fin rays have retrorsely curved distal segments (Fig. 42, rc). The second and third branched rays are shorter, forming a central notch in the distal margin of the anal fin. Posterior branched rays are normally developed, forming a rounded posterior margin, about $20 \%$ more elongated than the anterior margin.

The caudal-fin upper lobe is more elongated in mature males. Sexual dimorphism is not investigated as only young females are available.

Distribution. Tatia strigata is recorded from central Amazon basin, Negro river and Casiquiare Channel (Fig. 6). Tatia strigata is sympatric with T. dunni in the Casiquiare Channel and Negro river.

Remarks. Four branched pectoral-fin rays in T. strigata is not a common count within the genus. Species of Tatia with only four branched pectoral-fin rays are T. boemia, T. gyrina, T. meesi, some T. neivai and some T. intermedia.

A male anal fin with a notched distal margin is observed in both $T$. strigata and $T$. aulopygia, but the position of the notch is different. In T. strigata the notch is formed by reduc- 
tion of the second and third branched rays vs. reduction of fourth and fifth branched rays in T. aulopygia. The notched distal margin in male anal fin is not restricted to Tatia. Such a condition is also observed in Glanidium leopardus, with shortening of the fourth to sixth branched rays.

Material examined. 80 specimens (16.3-55.0 mm SL). Holotype. Brazil: Amazonas: MZUSP 44065, male (38.9 mm SL), Maués, igarapé Limãozinho (holotype of Tatia strigata). Paratypes. Brazil: Amazonas: MCZ 78092, 1 (55.0 mm SL), lake Cristalino, off Negro river near Manaus; MZUSP 7357, 35 (20.5-38.6 mm SL), Maués, igarapé Limãozinho; MZUSP 7298, 23 (16.3-31.2 mm SL) and MZUSP 44066, 2 CS (37.0-38.9 mm SL), Maués, igarapé of Marau river; MZUSP 44069, 1 CS female (29.4 mm SL), Canumã, igarapé on the left margin of Canumã river. Venezuela: ANSP 165795 , 5 (24.5-30.0 mm SL), Amazonas: brook of Casiquiare river, downstream from mouth of Pamoni river (paratypes of Tatia strigata).

\section{Key to species of Tatia:}

1. Nasal ossified, tubular, not sutured to mesethmoid. Caudal peduncle depth less than $13.1 \%$ SL. Adult size between $28.0-46.6 \mathrm{mmSL}$

1'. Nasal ossified with wide medial flanges partially sutured to lateral margins of mesethmoid (Fig. 8). Caudal peduncle depth greater than $13.6 \%$ SL. Adult size greater than 48.0 mmSL .................................................. 4
2. Lower jaw slightly protruding beyond upper; prevomer small, with rostro-lateral process limited in size; ribs 5-6; post-Weberian vertebrae 29-30. Mature males with externally elongate deferent duct and swollen anal-fin base (Fig. 26). Ground color whitish with brown spots, pattern mottled or irregularly striped. Ventral surface of head covered with short brown irregular stripes. Body with characteristic dark band along lateral line ....

................Tatia gyrina (Fig. 25, Amazon and Suriname)

2'. Jaws equal in length; prevomer arrow-shaped with welldeveloped rostro-lateral process; ribs 7-9; post-Weberian vertebrae 32-34. Mature males with short emergent deferent duct and thick anal-fin base (Fig. 18 and 32). Ground color brownish. Ventral surface of head whitish or brownish around chin barbels; no dark band along lateral line...3

3. Cranial fontanel relatively narrow with two openings, anterior one between mesethmoid and frontal and posterior one limited to frontal (Fig. 31); infraorbital 1 with short ventral process, restricted to anterior border of eye; pectoral-fin I,4; snout depth $44.8 \%$ HL or less ..................

Tatia meesi (Fig. 30, Essequibo)

3'. Cranial fontanel wide, with single opening (Fig. 17); infraorbital 1 with pronounced ventral process, almost reaching ventral border of eye; pectoral-fin I,5; snout depth $46.8 \% \mathrm{HL}$ or more ..... ........Tatia caxiuanensis (Fig. 16, Curuá, lower Amazon)

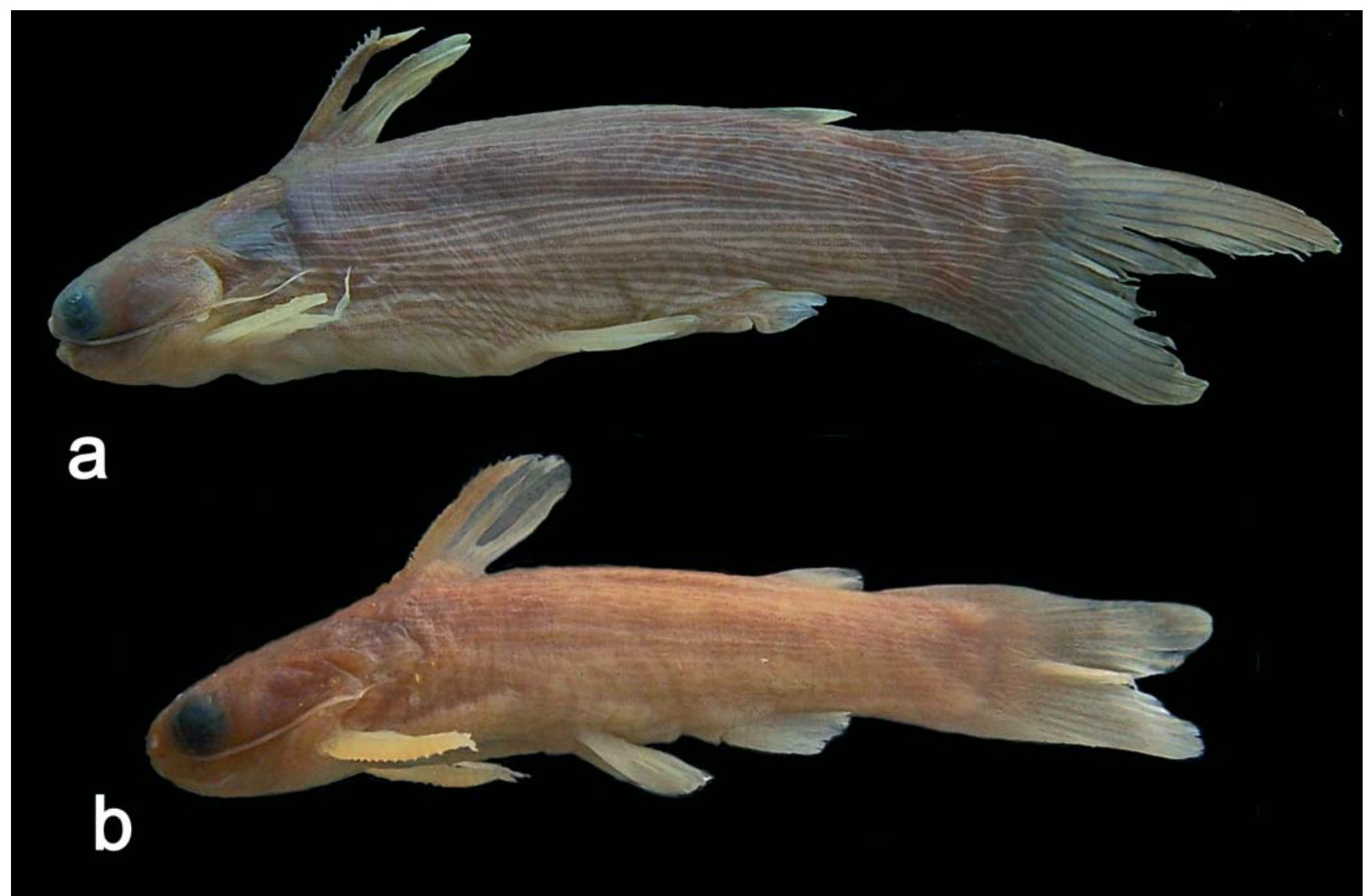

Fig. 40. Tatia strigata. (a) paratype, MCZ 78092, male, $55.0 \mathrm{~mm}$ SL, Negro river, Amazonas State, Brazil. (b) paratype, MZUSP 7298, female, $31.2 \mathrm{~mm}$ SL, Marau river, Amazonas State, Brazil. 


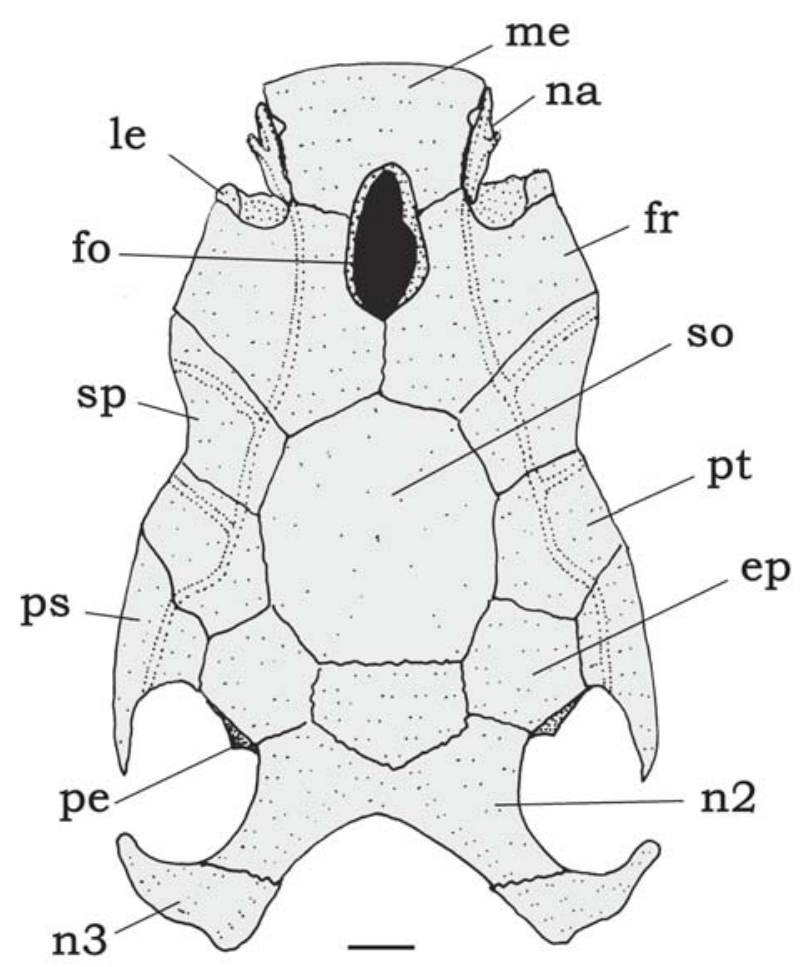

Fig. 41. Neurocranium of Tatia strigata, MZUSP 44066, 38.9 mm SL. Dorsal view. Abbreviations: ep, epioccipital; fo, single cranial fontanel, fr, frontal; le, lateral ethmoid; me, mesethmoid; na, nasal; n2; second nuchal plate; n3, third nuchal plate; pe, posterior epioccipital process; ps, posttemporalsupracleithrum; pt, pterotic; so, supraoccipital; sp, sphenotic. Scale bar $=1.0 \mathrm{~mm}$.

4. First nuchal plate small, rounded (Fig. 11); pectoral fin usually I,4, sometimes I,5; eye relatively small, 17.4-24.2\% HL; last two precaudal centra posterior to the Weberian apparatus alternatingly unribbed and ribbed

5

4'. First nuchal plate large, somewhat pentagonal (Fig. 37); pectoral fin usually I, 5, sometimes I, 4; eye relatively large, 21.4-33.0\% HL; all post-Weberian vertebrae consecutively ribbed.

5. Pectoral-fin spine, $22.0-27.1 \% \mathrm{SL}$; mouth width $47.9-52.9 \%$ HL; post-Weberian vertebrae 31-33; color pattern brownish dorsally, irregularly speckled over sides of body; caudal fin with irregular dark bars

Tatia neivai (Fig.33, upper Paraná-Paraguay)

5'. Pectoral-fin spine, 19.8-21.8\% SL; mouth width 39.0-43.2\% HL; post-Weberian vertebrae 34 ; color pattern greyishbrown dorsally, with small dark chromatophores over lateral and dorsal parts of body; caudal fin pale, with small spots over distal portions of rays

Tatia boemia (Fig. 10, upper Uruguay)

6. Postcleithral process long, 15.6-21.8\% SL, almost reaching vertical through origin of dorsal fin; pelvic-fin tip whitish ...7

6'. Postcleithral process short, 12.0-14.4\% SL, not reaching vertical through origin of dorsal fin; pelvic-fin tip dark Tatia nigra (Fig. 36, central and lower Amazon).

7. Snout length 23.1-33.3\% HL; eye 27.1-42.9\% HL; ribs 7; post-Weberian vertebrae less than $34 \ldots \ldots \ldots \ldots \ldots \ldots . . . . .68$

7'. Snout length 36.1-44.3\% HL; eye 21.4-26.5\% HL; ribs 9-11; post-Weberian vertebrae more than 33 ................9

8. Narrow elliptical cranial fontanel (Fig. 23); eye 37.0-42.9\% HL; pectoral fin with 5 branched rays; post-Weberian vertebrae typically $32-33$, rarely 30 ; sides of body usually dark with light rounded spots, or sometimes uniformly pale brown ................... Tatia galaxias (Fig. 22, Orinoco)

8'. Large cranial fontanel (Fig. 41); eye 27.1-30.3\% HL; pectoral fin with 4 branched rays; post-Weberian vertebrae 29-30; sides of body dark with light, narrow, irregular, longitudinal stripes... Tatia strigata (Fig. 40, central Amazon and Negro)

9. Cranial fontanel long, extending between mesethmoid and frontal (Fig. 28); mature male genital papilla without skin flap around deferent duct (see Fig. 9); notch absent from distal margin of modified anal fin in mature males (i.e., central fin rays not reduced); third anal-fin ray in males comparatively long, between 7.5-10.0\% SL; post-Weberian vertebrae 34-36.

Table 13. Morphometric data for Tatia strigata. SD = standard deviation.

\begin{tabular}{|c|c|c|c|c|}
\hline & Range & Mean & SD & $\mathrm{N}$ \\
\hline Standard length & $36.5-55.0$ & 43.2 & 10.28 & 5 \\
\hline \multicolumn{5}{|c|}{ Percents of standard length } \\
\hline Body depth & $12.6-18.7$ & 15.7 & 2.3 & \\
\hline Body width & $19.5-23.8$ & 22.0 & 1.3 & 5 \\
\hline Caudal peduncle depth & $13.6-14.5$ & 13.9 & 0.8 & 5 \\
\hline Caudal peduncle length & $24.2-29.2$ & 25.9 & 1.6 & \\
\hline Predorsal length & $31.5-36.4$ & 33.8 & 1.6 & 5 \\
\hline Preanal length & $62.8-70.9$ & 64.8 & 1.8 & 5 \\
\hline Prepelvic length & $45.1-52.6$ & 47.7 & 2.5 & \\
\hline Dorsal origin to pectoral origin & $20.8-24.1$ & 22.5 & 1.1 & \\
\hline Dorsal origin to pelvic origin & $21.8-33.8$ & 27.0 & 3.8 & \\
\hline Pectoral origin to pelvic origin & $28.6-34.2$ & 31.6 & 1.7 & \\
\hline Prepectoral length & 20.5-24.4 & 22.4 & 1.1 & \\
\hline Dorsal-fin base length & $10.2-13.2$ & 12.0 & 1.0 & \\
\hline Adipose-fin base length & $9.3-12.4$ & 11.3 & 0.8 & \\
\hline Anal-fin base length & $4.2-11.0$ & 5.9 & 1.0 & \\
\hline Dorsal-fin spine length & $16.7-21.9$ & 18.5 & 2.1 & 5 \\
\hline Pectoral-fin spine length & $17.7-25.9$ & 23.1 & 2.7 & 5 \\
\hline Postcleithral process lenght & 15.6-19.9 & 17.4 & 1.4 & 5 \\
\hline First branched pelvic-fin ray & $12.4-16.0$ & 14.5 & 1.2 & 5 \\
\hline Longest anal fin ray & $6.8-11.7$ & 7.9 & 1.0 & 5 \\
\hline Maxillary barbel length & $26.8-30.7$ & 29.0 & 2.0 & 5 \\
\hline Outer mental barbel length & 7.9-8.7 & 8.3 & 0.4 & 5 \\
\hline Mental barbel length & $6.0-6.3$ & 6.1 & 0.2 & 5 \\
\hline Head length & $25.5-30.4$ & 27.7 & 1.6 & 5 \\
\hline \multicolumn{5}{|c|}{ Percents of head length } \\
\hline Head width & $70.1-76.7$ & 72.3 & 2.0 & \\
\hline Snout depth & $41.3-47.3$ & 43.2 & 1.9 & 5 \\
\hline Interorbital distance & $49.4-54.8$ & 51.7 & 1.5 & 5 \\
\hline Left internarial width & $16.9-20.6$ & 19.0 & 1.3 & 5 \\
\hline Anterior internarial distance & $39.0-44.1$ & 40.7 & 1.5 & 5 \\
\hline Posterior internarial distance & $32.0-36.9$ & 35.0 & 1.7 & 5 \\
\hline Snout length & $31.2-33.3$ & 33.2 & 2.0 & 5 \\
\hline Orbital diameter & $27.1-30.3$ & 29.1 & 1.9 & 5 \\
\hline Mouth width & $41.6-47.9$ & 44.3 & 1.7 & 5 \\
\hline
\end{tabular}




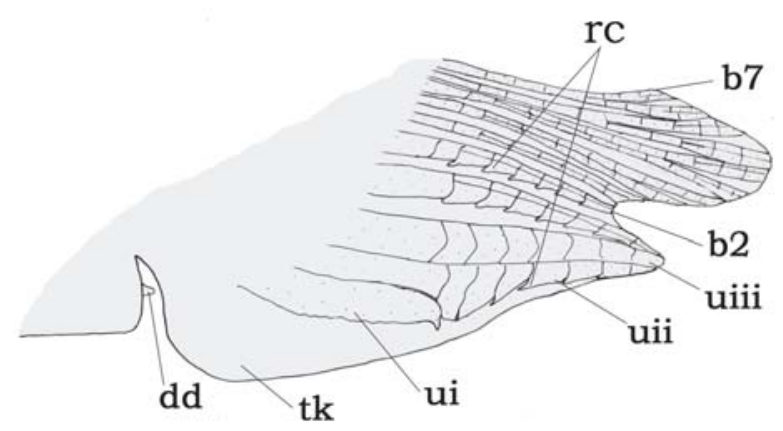

Fig. 42. Male modified anal fin of Tatia strigata, MCZ 78092, $55.0 \mathrm{~mm}$ SL. Left side lateral view. Abbreviations: b2, branched second ray; b7, branched seventh ray; dd, deferent duct; rc, retrorsely curved denticulation; tk, tegumentary keel; ui, unbranched first ray; uii, unbranched second ray; uiii, unbranched third ray. Scale bar $=1 \mathrm{~mm}$.

9'. Cranial fontanel short, opening restricted to frontal (Fig. 8); mature male genital papilla with thick skin flap around deferent duct; notch present in distal margin of modified anal fin in mature males (i.e., central fin rays reduced); third anal-fin ray in males comparatively short, between 5.2-7.0\% SL; post-Weberian vertebrae 38-39.

Tatia aulopygia (Fig. 7, upper Madeira)

10. Body coloration variable: usually with ellipsoid spots present on body and caudal fin (Fig. 27 b,c), or sometimes coloration uniformly brown; caudal fin pale (Fig. 27a); large adult specimens (>72 mm SL) usually with prevomerine teeth; male modified anal fin with 3-6 elongate antrorse denticulations along distal anterior margin of third unbranched ray (Fig. 29) ................... Tatia intermedia (Fig. 27, Guyana, Suriname, French Guiana, Amapá and eastern Pará, Brazil, lower Amazon and Tocantins)

10'. Body coloration mottled with irregular blotches or stripes; caudal fin with whitish spots or blotches; no prevomerine teeth, even in large adult specimens; male modified anal fin with sharp distal tip and 1-3 short antrorse denticulations along distal anterior margin of third unbranched ray (Figs.14 and 20) .................................. 11

11. Head width 76.0-80.1\% HL; mouth width $48.1-52.3 \%$ HL; pectoral-fin spine uniformly dark brown, without transverse bands; anal-fin rays usually iii, 6-7; modified anal fin in mature males with first unbranched ray unsegmented (Fig. 21) ................. Tatia dunni (Fig. 19, upper Amazon)

11'. Head width 86.6-93.4\% HL; mouth width 54.0-59.7\% HL; pectoral-fin spine usually with tranvese dark bands; anal-fin rays usually iii, 7-8; modified anal fin in mature males with first unbranched ray divided into 3-4 segments (Fig. 15) ........ Tatia brunnea (Fig. 13, Negro and Suriname, French Guyana)

\section{Acknowledgments}

This work began as part of a Doctoral thesis by the senior author, at the Instituto de Biociências da Universidade de São Paulo. We are grateful to Heraldo A. Britski for assistance and facilities provided at MZUSP and for helpful suggestions on various topics related to this paper. We thank the staff at the Museu de Zoologia, specially Angela Zanata, Mauro Triques, Mônica T. Piza, Osvaldo Oyakawa, Sandra Favorito and Rosana Souza Lima for their assistance during the beginning of this study. We are grateful to Arion T. Aranda, Gustavo W. Nunan, Leonardo Ingenito, Marcelo R. Britto, Mirian Santanna Ghazzi and Paulo A. Buckup at the Museu Nacional. We thank our colleagues at the Museu de Biologia Mello Leitão, Gustavo M. Prado, Helio Q. Boudet and Mikael M. Martinelli for their assistance by the end of present work. For loans, exchange of specimens and/or courtesies extended during visits to their institutions we thank Melanie Stiassny, Scott A. Schaefer (AMNH), Mark H. Sabaj, William G. Saul (ANSP), Jonathan Armbruster, David Werneke (AUM), Nigel R. Merrett (BMNH); W. Eschmeyer and Carl J. Ferraris (CAS), Mark Westneat, Barry Chernoff(FMNH), Mike Retzer(INHS), Efrem J. G. Ferreira, Lucia Rapp Py-Daniel, Jansen Zuanon (INPA), Donald Taphorn (MCNG), Érica P. Caramaschi, Wilson J.E.M. Costa (UFRJ), Roberto E. Reis (MCP), Karsten E. Hartel (MCZ), Claude Weber (MHNG), J. C. Hureau (MNHN), Horácio Higuchi, Luciano Montag, Wolmar Wosiacki (MPEG), Oscar A. Shibatta (MZUEL), Heraldo A. Britski and Osvaldo T. Oyakawa (MZUSP), Paulo A. Buckup, Gustavo W. Nunan, Arion T. Aranda (MNRJ), Barbara Herzig and Ernst Mikschi (NMW), Carla S. Pavanelli (NUPELIA), M. van Oijen, Gerloff F. Mees (RMNH), Richard P.Vari (USNM), Lawrence M. Page(UF), Isaäc J.H. Isbrücker, H. Nijssen (ZMA) and William Fink (UMMZ). For photographs, radiographs and/or information about species we are indebted to Abercio A. Pereira, Alberto Akama, Eugenia Böhlke, Érica P. Caramaschi, Dario A. Alboth, Flávio C.T. Lima, Heraldo A. Britski, James C. Coelho, Jansen Zuanon, Lawrence M. Page, Luciano Montag, Michael Goulding, M. Norma Feinberg, Oscar A. Shibatta, Paulo Petry, Ramiro Royero, Sandra Raredon, Suzanne Wernet and Walter R. Koch. We are grateful to the image bank of the All Catfish Species Inventory webpage. A Doctoral Grant provided by the Fundação de Amparo à Pesquisa do Estado de São Paulo (FAPESP), gave part of the finantial support during the beginning of the present study. The senior author received finantial support by the Conselho Nacional de Desenvolvimento Científico e Tecnológico (CNPq) during the final phase of this study. The paper benefited from the comments and suggestions of Marcelo R. Britto (MNRJ) and Mark H. Sabaj (ANSP).

Comparative material. Asterophysus batrachus: Brazil: MNRJ 915, 1, Brazil: Amazonas: upper Negro river, frontier Brazil with Venezuela. MNRJ 985, 1 CS, Brazil: Amazonas: Manaus. MZUSP 12420, 1, Brazil: Amazonas: Negro river, Paricatuba. Glanidium albescens: UZMK 335, 1, R, $101 \mathrm{~mm}$ SL; syntype and UZMK 336, 1, R (94 mm SL) syntype, Brazil: Minas Gerais: das Velhasr river. Glanidium bockmanni: MZUSP 82803, 1, male, $48.0 \mathrm{~mm} \mathrm{SL}$; holotype; MZUSP 36976, 1, male, $37.2 \mathrm{~mm} \mathrm{SL}$; paratype and MZUSP 82804, 1, male, 41.4 mm SL (CS); paratype; Brazil: Minas Gerais: São Francisco river, downstream from Três Marias Dam. MNRJ 25798, 1, juvenile male, 27.5 mm SL, Brazil: Minas Gerais: Jequitaí river $\left(17^{\circ} 11^{\prime} 15^{\prime}\right.$ 'S $\left.44^{\circ} 29^{\prime} 30^{\prime \prime}\right)$ at Jequitaí, close to Fran- 
cisco Dumont. MZUSP 82351, 8, 3 female and 5 male, 29.4-35.8 mm SL (1 CS), Brazil: Bahia: Preto river $\left(11^{\circ} 02^{\prime} 59.7^{\prime} \mathrm{S}\right.$; $45^{\circ} 11^{\prime} 31.1$ 'W) at Formosa do Rio Preto. Glanidium cesarpintoi: MZUSP 43251. 7. 1 CS, 33.0-38.9 mm SL, Brazil: São Paulo: 1lha Solteira: Paraná river. Glanidium leopardum. Suriname. RMNH 28573. 2, 56-71 mm SL and RMNH 28576. 3. 1 CS 37.5-71.2 mm SL, Suriname: Balaté river. Glanidium melanopterum: Brazil. USNM 41506, .98.6 mm SL: Brazil: Rio de Janeiro: Paraíba do Sul river, MNRJ 12137, 2, 107-134.5 mm SL, Brazil: Rio de Janeiro: Juturnaíba lagoon, between Araruama and Silva Jardim. MNRJ 12359, 1 CS, Brazil: Rio de Janeiro: Três Rios: Paraíba do Sul river. Glanidium ribeiroi: Brazil. FMNH 54243, 1. 134.4 mm SL: holotype, Brazil: Paraná: Porto União da Vitória. Centromochlus concolor: Suriname: ZMA 106.209, 2, R, 29.4-30.6 mm SL; paratypes and ZMA 106.210, 1, R, $33.4 \mathrm{~mm}$ SL; paratype of Tatia concolor, Suriname: Coppename river. Centromochlus existimatus. Brazil. FMNH 98265, 2 CS, Brazil: Pará: Santarém. Peru. USNM 306028, 1, R, 72.9 mm SL; Peru: Ucayali: Pucallpa: Ucayali river, Nuevo San Juan. Centromochlus heckelii. Brazil. MZUSP 48910, 2, 80-83.2 mm SL, Brazil: Acre: Acre river between seringal Paraíso and Amapá lagoon. MZUSP 44128, 3, 69.8-77 mm SL; and MZUSP 44129, 1, CS. Brazil: Amazonas: Pauini. Colombia. NMW 47359, 1, $69 \mathrm{~mm}$ SL; syntype of Centromochlus megalops. Colombia: Bogotá. Venezuela. MCNG 23921, 2, 83.7-83.8 mm SL; Venezuela, Amazonas: Orinoco river in Porto Venado. Centromochlus perugiae. Colombia. USNM 121965, 1, 35.5 mm SL; Colombia: Dedo river, tributary of Orteguazo river. Ecuador. FMNH 92005, I. CS, Ecuador: Rutun Celutu river. Peru. ANSP 139045. 1, 43.9 mm SL: Peru: Huanuco: Huallaga river, near Tingo Maria. MZUSP 26684, 4, 1 CS, 26.2-35.9 mm SL; Caserio Neshuya, Peru: Ucayali: Pucallpa river. USNM 273574, 1, 39 mm SL; Peru: Ucayali: Pucallpa: Neshuya: Tahuayo river. ZMA 115.446, 4, R, 27.6-35.6 mm SL; Peru: Ucayali: Pucallpa: Huacamaya river on road Pucallpa to Tingo Maria, East of Aguaytia. Centromochlus punctatus. Suriname. RMNH 26496, 3. R. 36.2-39.3 mm SL, paratypes of Tatia punctata, Suriname: rivers between Kabel and Lombé. Centromochlus reticulatus. Colombia. ANSP 128707. 7, 23.5-34.3 mm SL; Colombia: Emma brook in Finca El Viento about 33.5 Km NW of Puerto Lopez. Guyana. RMNH 26744, 2, R, 19.5-23.6 mm SL. paratypes of Tatia reticulata, Guyana: Karanambo: Rupununi. Centromochlus romani. Venezuela. AMNH 91382, 2, 32.5-32.7 mm SL, Venezuela: Amazonas: Siapa river, Negro river drainage. INHS 27999, 6, 27.5-30.9 mm SL, Venezuela: Barinas: Michay river, Apure river drainage. Centromochlus schultzi. Brazil. MNRJ 12139, 10 of 38, I CS, 85-108.9 mm SL; Brazil: Goiás: Serra da Mesa river dam, upper Tocantins river. MNRJ 9417. 2. 32.7-60.8 mm SL, Brazil: Mato Grosso: upper Xingu river. Gelanoglanis stroudi: Colombia. ANSP 142938, 5, 2 R, 25.9-36.6 mm SL; paratypes and MZUSP 14641, $1 \mathrm{R}, 25.4 \mathrm{~mm}$ SL; paratype, Colombia, Meta: Metica river, Meta river drainage. ANSP 142941, 1, CS, $23.9 \mathrm{~mm}$ SL paratype and FMNH 83912, 1, CS, 24.6 mm SL; paratype, Colombia, Meta: Manacacias river, east of Puerto Gaitan. Centromochlus musaicus. Venezuela. MBUCV-V 17727, 1, $24.3 \mathrm{~mm}$ SL paratype, Venezula: Amazonas: San Fernando de Atabapo: Atabapo river. MCNG 21796, 1, $50.8 \mathrm{~mm}$ SL, Venezuela: Amazonas: brook La Chimita. AMNH 58795, 3, $28.2 \mathrm{~mm}$ SL, paratype, Venezuela: Amazonas: San Fernando de Atabapo: Atabapo river. Centromochlus simplex. Brazil. BMNH 1971.7.29:5, 1, 28.5 mm SL, holotype, Brazil: Mato Grosso: Xaventina: das Mortes river. MZUSP 44071, 1, $49.3 \mathrm{~mm}$ SL, Brazil: Pará: Jatobal: Tocantins river. MZUSP 44074, 1, 26.6 mm SL, Brazil: Pará: Jatobal: lake near Capitariquara channel. MZUSP 36862, 3, 28.4-46.4 mm SL, Brazil: Pará: Xingú river.

\section{Literature Cited}

Bamford, T. W. 1948. The cranial development of Galeichthys felis. Proceedings of the Zoological Society of London, 118: 364391.

Birindelli, J. L. O., M. H. Sabaj \& D. C. Taphorn. 2007. New Species of Rhynchodoras from the Río Orinoco, Venezuela, with Comments on the genus (Siluriformes: Doradidae). Copeia, 2007: 672-684.

Boeseman, M. 1953. Scientific results of the Suriname Expedition 1948-1949. Part II. Zoology no. 2. The Fishes (I). Zoologische Mededelingen (Leiden), 32: 1-24.

Böhlke, J., S. H. Weitzmann \& N. A. Menezes. 1978. Estado atual da sistemática de peixes de água doce da América do Sul. Acta Amazonica, 8: 657-677.

Böhlke, E. B. 1984. Catalog of type specimens in the ichthyological collection of the Academy of Natural Sciences of Philadelphia. Special Publication 14: 1-246.

Britski, H. A. 1972. Peixes de água doce do estado de São Paulo: sistemática. Pp.79-108. In: Comissão Inter-Estadual da Bacia Paraná-Uruguay. Poluição e piscicultura. São Paulo, Faculdade de Saúde Pública da USP, Instituto de Pesca, 108p.

Britski, H. A., K. Z. Silimon \& B. S. Lopes. 1999. Peixes do Pantanal: manual de identificação. Embrapa, Brasília, 184p.

Burgess, W. E. 1989. An atlas of freshwater and marine catfishes. A preliminary survey of the Siluriformes. T.F.H. Publications, Neptune City, New Jersey, 784p.

Burgess, W. E. \& L. Finley. 1996. An atlas of freshwater and marine catfishes: Update. Tropical Fish Hobbyist, 1996: 163-174.

Burns, J. R., S. H. Weitzman \& L. R. Malabarba. 1997. Insemination in eight species of cheirodontine fishes (Teleostei: Characidae: Cheirodontinae). Copeia, 1997: 433-438.

Casatti, L., F. Langeani \& R. M. C. Castro. 2001. Peixes de riacho do Parque Estadual Morro do Diablo, bacia do Alto rio Paraná, SP. Revista Biota Neotropica, 1: 1-15.

Chang, F. \& H. Ortega. 1995. Additions and corrections to the list of freshwater fishes of Peru. Publicaciones Museo Historia Natural, Universidad Nacional Mayor de San Marcos Serie A Zoologia, 50: 1-11.

Curran, D. J. 1989. Phylogenetic relationships among the catfish genera of the family Auchenipteridae (Teleostei: Siluroidea). Copeia, 1989: 408-419.

Diogo, R. \& M. Chardon. 2000. The structures associated with catfish (Teleostei: Siluriformes) mandibular barbels: origin, anatomy, function, taxonomic distribution, nomenclature and synonymy. Netherlands Journal of Zoology, 50: 455-478.

Eigenmann, C. H. 1910. Catalog of the fresh-water fishes of Tropical and South-temperate America. Reports of the Princeton University expeditions to Patagonia, 1896-1899. Princeton University, 3(4): 375-511.

Eigenmann, C. H. 1912. The freshwater fishes of British Guiana, including a study of the ecological grouping of species and the relation of the fauna of the plateau to that of the lowlands. Memoirs of the Carnegie Museum 5: 1-578.

Eigenmann, C. H. \& W. R. Allen. 1942. Fishes of western South America. I. The intercordilleran and Amazonian lowlands of Peru. II.-The high pampas of Peru, Bolivia, and northern Chile. With a revision of the Peruvian Gymnotidae, and of the genus Orestias. University of Kentucky. 494p.

Eigenmann, C. H. \& R. S. Eigenmann. 1888. Preliminary notes on South American Nematognathi, I. Proceedings of the California Academy of Sciences (Ser. 2), 1 (part 2): 119-172. 
Eigenmann, C. H. \& R. S. Eigenmann. 1890. A revision of the South American Nematognathi or cat-fishes. Occasional Papers of the California Academy of Sciences, 1: 1-508.

Eigenmann, C. H. \& R. S. Eigenmann. 1891. A catalogue of the fresh-water fishes of South America. Proceedings of the United States National Museum, 14: 1-81

Ferraris, C. J., Jr. 1988. The Auchenipteridae: Putative monophyly and systematics, with a classification of the neotropical doradoid catfishes (Ostariophysi: Siluriformes). Unpublished doctoral dissertation, The City University of New York. 229p.

Ferraris, C. J., Jr. 2003. Auchenipteridae. Pp. 470-482. In: R.E. Reis, S.O. Kullander \& C.J. Ferraris, Jr. (eds.), Check list of the freshwater fishes of South and Central America. Edipucrs, Porto Alegre, Brazil. 729p.

Ferraris, C. J., Jr. 2007. Checklist of catfishes, recent and fossil (Osteichthyes: Siluriformes), and catalogue of siluriform primary types. Zootaxa, 1418: 1-628.

Ferraris, C. J., Jr. \& J. Fernandez. 1987. Trachelyopterichthys anduzei, a new species of auchenipterid catfish from the upper Rio Orinoco of Venezuela with notes on T. taeniatus (Kner). Proceedings of the Biological Society of Washington, 100: 257261.

Fink, S. V. \& W. L. Fink. 1996. Interrelationships of the Ostariophysi. Pp:209-249. In: Interrelationships of Fishes, M. Stiassny, L. Parenti \& D. Johnson, eds. Academic Press.

Fisher, H. G. 1917. A list of the Hypophthalmidae, the Diplomystidae and of some unrecorded species of Siluridae in the collections of the Carnegie Museum. Annals of the Carnegie Museum, 11: 405-427.

Fowler, H. W. 1945a. Los peces del Perú. Catálogo sistematico de los peces que habitan en aguas peruanas. Museo de Historia Natural "Javier Prado". Lima. 298 p.

Fowler, H. W. 1945b. Colombian zoological survey. Pt. I.B The freshwater fishes obtained in 1945. Proceedings of the Academy of Natural Sciences, Philadelphia, 97: 93-135.

Fowler, H. W. 1951. Os peixes de água doce do Brasil, 3. entrega. Arquivos Zoologia do Estado de São Paulo. 6: 405-624.

Franke, H. J. 1990. The first breeding of the starry woodcat, Tatia galaxias. Tropical Fish Hobbyist, 39: 20-34.

Gosline, W. A. 1945. Catálogo dos nematognatos de água-doce da América do Sul e Central. Boletim do Museu Nacional. Nova série, Zoologia, 33: 1-138.

Goulding, M., M. Leal Carvalho \& E. G. Ferreira. 1988. Rio Negro, rich life in poor water. SPB Academic Publishing, The Hague, The Netherlands, 200p.

Günther, A. 1864. Catalogue of the fishes in the British Museum, vol. 5: Catalogue of the Physostomi, containing the families Siluridae, Characinidae, Haplochitonidae, Sternoptychidae, Scopelidae, Stomiatidae in the collection of the British Museum. British Museum Trustees, London. 455p.

Hoedeman, J. J. 1957. Notes on the ichthyology of Suriname (Dutch Guiana), 4. Additional records of siluriform fishes (1). Beaufortia, 6: 147-160.

Hoedeman, J. J. 1968. Elseviers aquariumvissen encyclopedie, I. Amsterdam/ Brussel: 1-188.

Ihering, R. von. 1937. Oviductal fertilization in the South American catfish Trachycorystes. Copeia, 1937: 201-205.

Ihering, R. von. 1930. Notas ecológicas referentes a peixes d'água doce do Estado de S. Paulo e descripção de 4 espécies novas. Archivos do Instituto Biológico, São Paulo, 3: 93-103, pl. 13.

Jordan, D. S. 1920. The genera of fishes, part IV, from 1881 to 1920, thirty-nine years, with the accepted type of each. A contribution to the stability of scientific nomenclature. Leland Stanford Jr. University Publications, 43: 411-576.

Kner, R. 1858. Ichthyologische beiträge. Sitzunberische der Akademie Wissenchaften in Wien, Mathem.-Naturw. Cl., 26: 373-448.

Kobayagawa, M. 1991. The world of catfishes. Edited by Warren E. Burgess. TFH Publications.

Koch, W. R. \& R. E. Reis. 1996. Tatia boemia, a new species of authenipterid catfish (Teleostei: Siluriformes) from the Rio Uruguay drainage, southern Brazil. Ichthyological Exploration of Freshwaters, 7: 85-90.

Lasso, C. A., V. Castelló, T. Canales-Tilve \& J. Cabot-Nieves 2001. Contribución al conocimiento de la ictiofauna del rio Paraguá, cuenca del rio Itenez o Guaporé, Amazonía Boliviana. Memorias Fundacion La Salle de Ciencias Naturales, 59: 89-103.

Lasso, C. A., J. I. Mojica, J. S. Usma, J. A. Maldonado, C. Do Nascimiento, D. C. Taphorn, F. Provenzano, Ó. M. LassoAlcalá, G. Galvis, L. Vásquez, M. Lugo, A. Machado-Allison, R. Royero, C. Suárez \& A. Ortega-Lara. 2004. Peces de la cuenca del rio Orinoco. Parte I: lista de especies y distribución por subcuencas. Biota Colombiana, 5: 95-158.

Lauzanne, L. \& G. Loubens. 1985. Peces del Rio Mamoré. ORSTOM, Travails et Documents 192, Paris. 116 p.

Le Bail, P.-Y., P. Keith \& P. Planquette. 2000. Atlas des poissons d'eau douce de Guyane. Tome 2 - fascicule II. Siluriformes. 1307.

Leviton, A. E., R. H. Gibbs Jr., E. Heal \& C. E. Dawson. 1985. Standards in Herpetology and Ichthyology. Part I. Standard Symbolic Codes for Institutional Resource Collections in Herpetology and Ichthyology. Copeia, 1985: 802-832.

Loir, M., C. Cauty, P. Planquette \& P. -Y. le Bail. 1989. Comparative study of the male reproductive tracts in seven families of South American catfishes. Aquatic Living Resource 2: 45-56.

Lowe-McConnell, R. H. 1964. The fishes of the Rupunnuni savanna district of British Guiana, South America. Part I. Ecological groupings of fish species and the effects of the seasonal cycle on the fish. Journal of the Linnean Society (Zoology), 45: 103144.

Lowe-McConnell, R. H. 1975. Fish communities in tropical freshwaters: their distribution, ecology and evolution. Longman, New York, 337p.

Lowe-McConnell, R. H. 1987. Ecological studies in tropical fish communities. Cambridge University Press, Cambridge, 382p.

Lüling, K. H. 1963. Die Quisto Cocha und ihre häufigen fische. Beitrage Neotropical Fauna, 3: 34-56.

Mago-Leccia, F. 1967. Notas preliminares sobre los peces de los llanos de Venezuela. Boletin de la Sociedad Venezuelana de Ciencias Naturales, 27: 237-263.

Mees, G. F. 1974. The Auchenipteridae and Pimelodidae of Suriname (Pisces, Nematognathi). Zoologische Verhandelingen, 132: 1256.

Mees, G. F. 1983. Naked catfishes from French Guiana (Pisces, Nematognathi). Zoologische Mededelingen (Leiden), 57: 4358.

Mees, G. F. 1985. Further records of Auchenipteridae and Pimelodidae from Suriname (Pisces: Nematognathi). Zoologische Mededelingen (Leiden), 59: 239-249.

Mees, G. F. 1988. Notes on the genus Tatia (Pisces, Nematognathi, Auchenipteridae). Proceedings of the Koninklijke Nederlandse Akademie van Wetenschappen (Series C), 91: 405-414.

Meisner, A. D., J. R. Burns, S. H. Weitzman \& L. R. Malabarba. 2000. Morphology and histology of the male reproductive 
system in two species of internally inseminating south american catfishes, Trachelyopterus lucenai and T. galeatus (Teleostei: Auchenipteridae). Journal of Morphology, 246: 131-141.

Ministério do Meio Ambiente. 2004. Lista Nacional das Espécies de Invertebrados Aquáticos e Peixes Ameaçadas de Extinção. Instrução Norminativa 5, Anexo I. Pp. 136-141. In: Diário Oficial da União, seção 1, no. 102, sexta-feira, 28 de maio de 2004. Imprensa Nacional.

Miranda Ribeiro, A. 1911. Fauna brasiliense. Peixes. Tomo IV (A) [Eleutherobranchios Aspirophoros]. Arquivos do Museu Nacional do Rio de Janeiro, 16: 1-504.

Miranda Ribeiro, A. 1918. Três gêneros e dezessete espécies novas de peixes Brasileiros. Revista do Museu Paulista, 10: 631-646.

Miranda Ribeiro, P. 1962. Catálogo dos peixes do Museu Nacional, IX. Publicações Avulsas do Museu Nacional, Rio de Janeiro, 45: $1-12$.

Miranda Ribeiro, P. 1968. Apontamentos ictiológicos IV. Boletim do Museu Nacional, Rio de Janeiro, Nova Série, Zoologia, 262: 1-7.

Nakatani, K., A. A. Agostinho, G. Baumgartner, A. Bialetzki, P. V. Sanches, M. C. Makrakis \& C. S. Pavanelli. 2001. Ovos e larvas de peixes de água doce: desenvolvimento e manual de identificação. Maringá: EDUEM, 378p.

Ortega, H. \& R. P. Vari. 1986. Annotated checklist of the freshwater fishes of Peru. Smithsonian Contributions to Zoology, 437: 125.

Pearson, N. E. 1937. The fishes of the Atlantic and Pacific slopes near Cajamarca, Peru. Proceedings of the California Academy of Sciences, 23: 87-98.

Pellegrin, J. 1899. Notes les poissons recueillis par M.F. Geay dans l'Apuré et sés affluents. Bulletin Musée de Histoire Naturelle de Paris 5: 156-159.

Puyo, J. 1949. Poissons de la Guyane française. Faune de l'empire Français. ORSOM, Paris, 12, 280 p.

Rössel, F. 1962. Centromochlus schultzi, ein neues wels aus Brasilien (Pisces, Teleostei, Auchenipteridae). Senckenbergiana Biologica, 43: 27-30.

Royero, R. 1992. Tatia musaica, una nueva especie de bagre auquenipterido (Siluriformes -Auchenipteridae) de la cuenca del Rio Orinoco, Territorio Federal Amazonas, Venezuela. Acta Cientifica Venezuelica, 43: 300-306.

Sands, D. 1984. Catfishes of the World. Catfishes of the world, 3, Suppl (first set): 58:1-8.

Sarmento-Soares, L. M. \& M. Porto. 2006. Comparative anatomy of the cheek muscles within the Centromochlinae subfamily (Ostariophysi, Siluriformes, Auchenipteridae). Journal of Morphology, 267: 187-197.
Schultz, L. P. 1944. The catfishes of Venezuela, with descriptions of thirty-eight new forms. Proceedings of the United States National Museum, 94: 173-338.

Soares-Porto, L. M. 1995. A new species of Tatia from the Amazon basin (Siluriformes: Auchenipteridae). Ichthyological Exploration of Freshwaters, 6: 201-206.

Soares-Porto, L. M. 1996. Análise filogenética dos Centromochlidae. Redefinição e revisão taxonômica de Tatia A. de Miranda Ribeiro, 1911 (Osteichthyes, Siluriformes, Doradoidea). Unpublished Doctoral Dissertation. Universidade de São Paulo, São paulo. $278 \mathrm{p}$.

Soares-Porto, L. M. 1998. Monophyly and interrelationships of the Centromochlinae (Siluriformes, Auchenipteridae), p. 331350, In: L. R. Malabarba, R. E. Reis, R. P. Vari, Z. M. S. Lucena \& C. A. S. Lucena (eds.). Phylogeny and Classification of Neotropical fishes.Edipucrs, Porto Alegre, 603p.

Steindachner, F. 1876. Die süsswasserfische des südöstlichen Brasilien. Sitzungsberichte der Akademie der Wissenschaften in Wien, Mathematisch-Naturwissenschaftlichen, 74: 559-694.

Steindachner, F. 1882. Beiträge zur kenntnis der flussfische Südamerika's, III. Denkschriften der Kaiserlinchen Akademie der Wissenschaften in Wien, MathematischNaturwissenschaftliche, 44: 1-18.

Taylor, W. R. \& G. C. Van Dyke. 1985. Revised procedures for staining and clearing small fishes and other vertebrates for bone and cartilage study. Cybium, 9: 107-119.

Vaillant, L. L. 1899. Note préliminaire sur les collections ichthyologiques recueillies par M. Geay en 1897 et 1898 dans la Guyane française et le Contesté franco-brésilien. Bulletin du Muséum d'Histoire Naturelle, Paris, 5: 154-156.

Vaillant, L. L. 1900. Contribution a l'étude de la faune ichthyologique de la Guyane Française et du Contesté franco-brésilien. Nouvelle Archives Musée de Histoire Naturelle de Paris, 2: 123-126.

Verissimo, S., C. S. Pavanelli, H. A. Britski \& M. M. Moreira. 2005. Fish Manso Reservoir region of influence, Rio Paraguay basin, Mato Grosso State, Brazil. Check List 1: 1-9.

Wallace, A. R. 2002. Peixes do Rio Negro [Fishes of the Rio Negro]. Organization, introductory text and translation by Mônica de Toledo-Piza Ragazzo. Editora da Universidade de São Paulo, São Paulo, Brazil. 517p.

ZFIN Project - The Zebrafish Information Network (ZFIN), University of Oregon, Eugene, OR 97403-5274; World Wide Web URL: http://zfin.org/zf_info/anatomy/dict/sum.html; [april, 3rd. 2008].

Accepted August, 2008

Published September 30, 2008 